\title{
IDENTIFICAÇÃO DE LEVEDURAS NO PROCESSO DE FERMENTAÇÃO ALCOÓLICA
}

\section{KÁTIA TERESINHA CABRINI}

Dissertacão apresentada à Escola Superior de Agricultura "Luiz de Queiroz", Universidade de São Paulo, para obtençăo do título de Mestre em Ciências, Área de Concentragảo: Ciência e Tecnologia de Alimentos.

PIRACICABA

Estado de São Paulo - Brasil

Outubro - 1997 


\title{
IDENTIFICAÇÃO DE LEVEDURAS NO PROCESSO DE FERMENTAÇÃO ALCOÓLICA
}

\author{
KÁTIA TERESINHA CABRINI \\ Bióloga
}

Orientador: Prof. Dr. CLÁUDIO ROSA GALLO

Dissertaça aprosentado à Escola Superior de Agricultura "Luiz de Queiroz", Univessidade de Sæ̋o Paulo, para obtenção do título de Mestre em Ciências, Área de Concenturação: Ciência e Tecnologia de Alimentos.

PIRACICABA

Estado de São Paulo - Brasil

Outubro - 1997 
Dados Internacionais de Catalogação na Publicação (CIP) DIVISÃo DE BIBLIOTECA E DOCUMENTAÇÃo - Campus "Luiz de Queiroz"/USP

Cabrini, Kátia Teresinha

Identificação de leveduras no processo de fermentação alcoólica / Kátia Teresinha Cabrini. - Piracicaba, 1997.

115 p. : il.

Dissertação (mestrado) - - Escola Superior de Agricultura Luiz de Queiroz, 1997. Bibliografia.

1. Fermentação alcoólica 2. Levedura (Identificaçāo) l. Título

CDD 663.13 


\title{
IDENTIFICAÇÃO DE LEVEDURAS NO PROCESSO DE FERMENTAÇÃO ALCOÓLICA
}

\author{
KÁTIA TERESINHA CABRINI
}

Aprovada em: 11.12.1997

Comissão julgadora:

Prof. Dr. Cláudio Rosa Gallo

ESALQ/USP

Prof. Dr. Jorge Horii

ESALQ/USP

Prof ${ }^{a}$. Dr ${ }^{a}$. Dejanira Franceschi de Angelis

Orientador 
À pessoas infinitamente especiais como Ceci, Rô, Geo, Wagner, Clau, Val e Dézinho...

...Os meus amigos fizeram a história da minha vida. De mil maneiras, transformaram as minhas limitações em privilégios maravilhosos e me permitiram caminhar serena e feliz na sombra lançada pela minha privação pessoal (Helen Keller). 
Ao amigo e orientador Cláudio, por todos os ensinamentos

Dedico 
Aos meus pais Ovídio e Therezinha, por todo amor

Ofereço 


\section{AGRADECIMENTOS}

Agradeço a todos que direta ou indiretamente contribuíram para a realização deste trabalho, particularmente:

Ao Prof. Dr. Cláudio Rosa Gallo, pela orientação, profissionalismo, confiança e amizade ao longo deste trabalho.

Ao Prof. Dr. Antônio Joaquim de Oliveira, pela sua efetiva participação, atenção e valiosas sugestões.

À CAPES, pela concessão da bolsa de estudo.

Às Usinas da Pedra e Santa Elisa e à Destilaria Mandú, pelas amostras enviadas.

À Fermentec S/C Ltda - Assistência Técnica em Fermentação Alcoólica, pelo auxílio financeiro às pesquisas.

Aos colegas e professores do curso de Ciência e Tecnologia de Alimentos, pelo enriquecimento à minha vida pessoal e profissional.

Aos funcionários do Departamento de Ciência e Tecnologia Agroindustrial, pela agradável convivência. 
Às bibliotecárias Beatriz Helena Giongo e Mídiam Gustinelli, pela constante dedicação.

Às técnicas e amigas Cecília, Denise, Rosalina e Cleomar, pela colaboração e alegrias compartilhadas.

Ao Prof. Maurilo do Carmo Silva, diretor do Colégio Técnico de Limeira (COTIL/UNICAMP), professores, funcionários e alunos, pelo apoio e incentivo sempre presentes.

Ao amigo Luís Fernando Chang de Oliveira, pela gentil execução de gráficos e tabelas.

À Deus, sem o Qual nada seria possível. 


\section{SUMÁRIO}

Página

LISTA DE FIGURAS................................................................................

LISTA DE TABELAS......................................................................ii

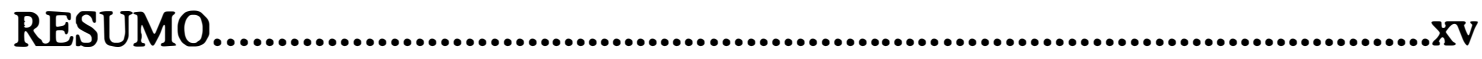

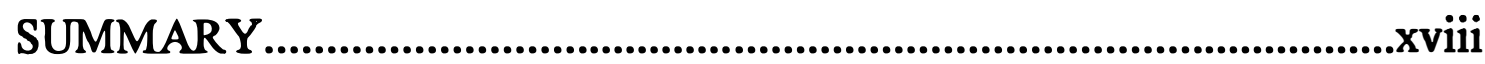

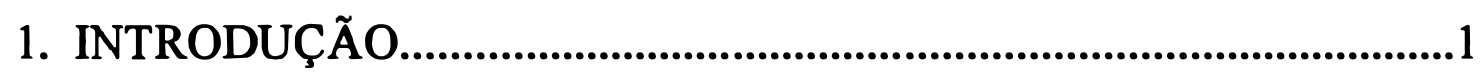

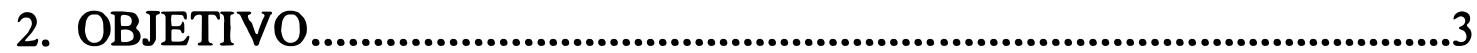

3. REVISÃO DE LITERATURA....................................................4

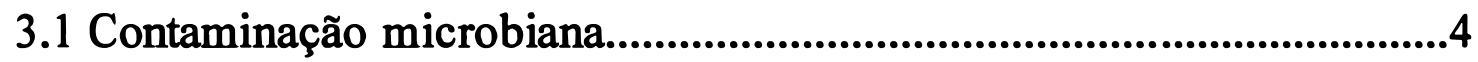

3.2 Agentes de fermentação alcoólica......................................................7

3.3 Leveduras contaminantes da fermentação alcoólica.............................10

4. MATERIAL E MÉTODOS............................................................19

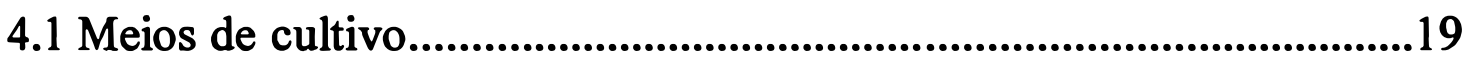

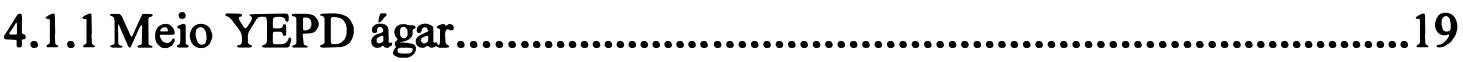

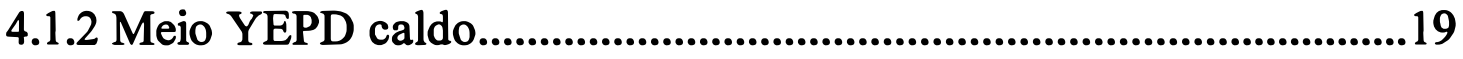

4.1.3 Meio basal para assimilação e fermentação de fontes de

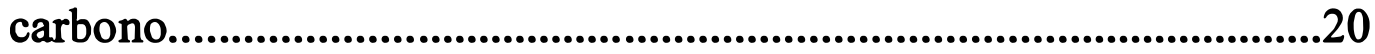

4.1.4 Meio de nitrato de potássio para teste de redução de nitrato à nitrito.

4.1.5 Meio YEPD caldo - 50\% glucose para teste de tolerância osmótica.

4.1.6 Meio YEPD caldo - $10 \%$ cloreto de sódio $(\mathrm{NaCl})$ para teste de tolerância osmótica. 
4.1.7 Meio de amido para teste de hidrólise de amido...............................21

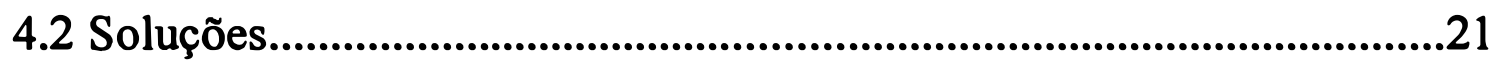

4.2.1 Solução crioprotetora para liofilização...............................................21

4.2.2 Solução estoque de cloranfenicol................................................22

4.2.3 Solução estoque de tetraciclina..................................................22

4.2.4 Soluções para teste de redução de nitrato à nitrito.............................22

4.2.5 Solução de lugol para teste de hidrólise de amido.............................23

4.3 Esterilização de meios de cultivo, soluções e materiais.......................23

4.3.1 Esterilização em autoclave a uma atmosfera de pressão, a

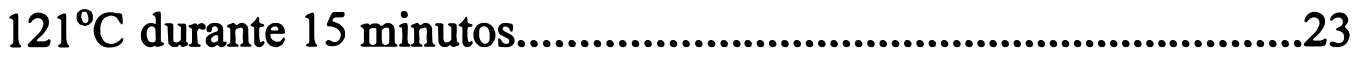

4.3.2 Esterilização em autoclave a uma atmosfera de pressão, a

$121^{\circ} \mathrm{C}$ durante 3 minutos................................................................24

4.3.3 Esterilização em estufa a $180^{\circ} \mathrm{C}$ durante duas horas........................24

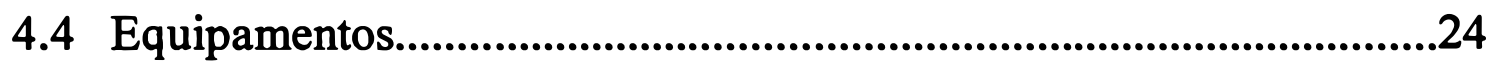

4.5 Amostras utilizadas para o isolamento de leveduras.........................25

4.6 Coleta, acondicionamento e transporte das amostras..........................26

4.7 Conservação das culturas brutas de leveduras presentes nas

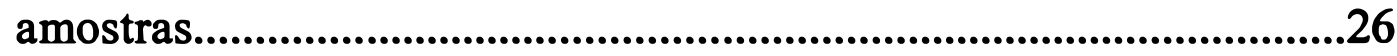

4.8 Isolamento, purificação e identificação de leveduras...........................29

4.8.1 Reativação das culturas brutas de leveduras....................................29

4.8.2 Isolamento e purificação das culturas de leveduras..........................29

4.8.3 Identificação de leveduras...............................................................32

4.8.3.1 Metodologia utilizada na identificação de leveduras......................32

4.8.3.2 Preparo do material utilizado na identificação de leveduras..........34

4.8.3.3 Condução dos testes para identificação de leveduras.......................35 


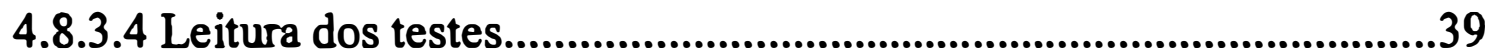

4.8.3.4.1 Teste de assimilação e fermentação de fontes de carbono..........39

4.8.3.4.2 Teste de crescimento das culturas à temperatura de $37^{\circ} \mathrm{C}$............39

4.8.3.4.3 Teste de tolerância osmótica das células.......................................40

4.8.3.4.4 Teste de redução de nitrato à nitrito.............................................40

4.8.3.4.5 Teste de hidrólise de amido.....................................................40

4.8.3.4.6 Observação do tamanho celular..................................................41

5. RESULTADOS E DISCUSSÃO...................................................42

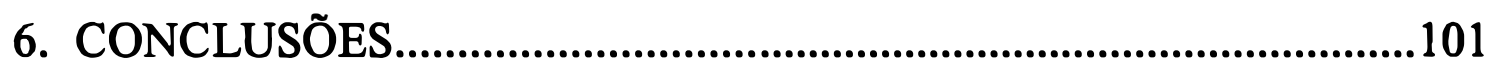

REFERÊNCIAS BIBLIOGRÁFICAS................................................104 


\section{LISTA DE FIGURAS}

Página

1. Esquema para liofilização das culturas brutas de leveduras obtidas a partir das amostras de caldo primário, mosto e leite de leveduras.

2. Esquema para isolamento e purificação de leveduras 31

3. Caracteres usados na obtenção dos códigos numéricos das espécies de leveduras.

4. Detalhe da grade de alumínio e do replicador manual. .37

5. Detalhe das placas mestras....................................................................38

6. Leveduras identificadas na Usina da Pedra

7. Leveduras identificadas na Usina Santa Elisa .45

8. Leveduras identificadas na Destilaria Mandú .45

9. Porcentagens dos isolados identificados no caldo primário na Usina da Pedra.

10.Porcentagens dos isolados identificados no mosto na Usina da Pedra. 
11.Porcentagens dos isolados identificados no leite de leveduras na Usina da Pedra.

12.Porcentagens dos isolados identificados no caldo primário na Usina Santa Elisà.

13.Porcentagens dos isolados identificados no mosto na Usina Santa Elisa.

14.Porcentagens dos isolados identificados no leite de leveduras na Usina Santa Elisa.

15.Porcentagens dos isolados identificados no caldo primário na Destilaria Mandú.

16.Porcentagens dos isolados identificados no mosto na Destilaria Mandú.

17.Porcentagens dos isolados identificados no leite de leveduras na Destilaria Mandú.

18.Gêneros de leveduras encontrados nas Usinas da Pedra, Santa Elisa e Destilaria Mandú. 


\section{LISTA DE TABELAS}

1. Número total de culturas isoladas e de culturas identificadas e

Página número de culturas identificadas em cada ponto amostrado nas Usinas da Pedra, Santa Elisa e na Destilaria Mandú.

2. Abreviações utilizadas para designar as espécies de leveduras citadas nas Figuras de 6 a 17

3. Leveduras identificadas nas amostras de caldo primário, mosto e leite de leveduras na Usina da Pedra

4. Leveduras identificadas nas amostras de caldo primário, mosto e leite de leveduras na Usina Santa Elisa.

5. Leveduras identificadas nas amostras de caldo primário, mosto e leite de leveduras na Destilaria Mandú.

6. Leveduras presentes nas amostragens mensais de caldo primário na Usina da Pedra.

7. Leveduras presentes nas amostragens mensais de mosto na Usina da Pedra 53

8. Leveduras presentes nas amostragens mensais de leite de leveduras na Usina da Pedra.

9. Leveduras presentes nas amostragens mensais de caldo primário na Usina Santa Elisa 
10. Leveduras presentes nas amostragens mensais de mosto na Usina Santa Elisa.

11. Leveduras presentes nas amostragens mensais de leite de leveduras na Usina Santa Elisa.

12. Leveduras presentes nas amostragens mensais de caldo primário na Destilaria Mandú.

13. Leveduras presentes nas amostragens mensais de mosto na Destilaria Mandú.

14. Leveduras presentes nas amostragens mensais de leite de leveduras na Destilaria Mandú. 


\title{
IDENTIFICAÇÃO DE LEVEDURAS NO PROCESSO \\ DE FERMENTAÇÃO ALCOÓLICA
}

\author{
Autora: KÁTIA TERESINHA CABRINI \\ Orientador: Prof. CLÁUDIO ROSA GALLO
}

\section{RESUMO}

Com o objetivo de se obter um levantamento da variedade de espécies de leveduras presentes em processos de fermentação para produção de álcool, procedeu-se a identificação de leveduras durante 1 semestre da safra 94/95 em 3 unidades industriais do Estado de São Paulo (Usina da Pedra, Usina Santa Elisa e Destilaria Mandú), utilizando-se amostras de caldo primário, mosto e leite de leveduras, coletadas mensalmente nestas unidades industriais.

A identificação das leveduras isoladas a partir das amostras acima, foi realizada de acordo com a taxonomia numérica proposta por Griffiths (1981), a qual baseia-se principalmente, em testes bioquímicos de assimilação e fermentação de fontes de carbono.

Foram isoladas 225 culturas de leveduras, das quais 195 puderam ser identificadas através da metodologia utilizada. 
Um total de 26 espécies de leveduras pertencentes a 7 gêneros, foram identificadas entre as 3 unidades industriais pesquisadas, sendo elas: Saccharomyces cerevisiae: S. uvarum ( $S$. cerevisiae), S. coreanus ( $S$. cerevisiae), S. bajanus, $S$. chevalieri ( $S$. cerevisiae), S. globosus ( $S$. cerevisiae), S. beticus ( $S$. cerevisiae), S. capensis (S. cerevisiae), $S$. pretoriensis (Torulaspora pretoriensis), Candida entomophila, $C$. membranaefaciens, C. rugosa, C. parapsilosis, C. rhagii, C. krusei: Torulopsis castellii (Candida castellii), Torulopsis dattila (Kluyveromyces thermotolerans), T. haemulonii (Candida haemulonii), T. inconspicua (Candida inconspicua), Pichia membranaefaciens, $P$. guilliermondii, $P$. ohmeri, P. etchellsii, P. spartinae, P. terricola (Issatchenkia terricola), Schizosaccharomyces pombe, Trichosporon brassicae e Rhodotorula glutinis. As leveduras indicadas entre parênteses correspondem à atualização das espécies segundo Barnett et al. (1983); Barnett et al. (1990) e Kreger-van Rij (1984).

A espécie Saccharomyces cerevisiae: S. uvarum (S. cerevisiae) foi a levedura dominante em todas as unidades industriais analisadas, apresentando freqüências de 34,95\% na Usina da Pedra, 32,79\% na Usina Santa Elisa e 35,3\% na Destilaria Mandú.

Na Usina da Pedra, a espécie Candida entomophila foi a levedura dominante no caldo primário, com freqüência de $30 \%$, enquanto que a espécie Saccharomyces cerevisiae: S. uvarum (S. cerevisiae) apresentou-se como dominante tanto no mosto como no leite de leveduras, com freqüências de $42,86 \%$ e $50 \%$, respectivamente.

$\mathrm{Na}$ Usina Santa Elisa, a espécie Torulopsis dattila (Kluyveromyces thermotolerans) apresentou-se como a levedura dominante 
tanto no caldo primário como no mosto, com freqüências de $31,25 \%$ e $26,6 \%$, respectivamente, enquanto que no leite de leveduras, Saccharomyces cerevisiae: $S$. uvarum ( $S$. cerevisiae) foi a espécie dominante, com freqüência de $45,96 \%$.

Igualmente como ocorrido na Usina da Pedra, a espécie Candida entomophila foi a levedura dominante no caldo primário na Destilaria Mandú, com freqüência de $60 \%$, apresentando-se também, Saccharomyces cerevisiae: S. uvarum (S. cerevisiae) como a espécie dominante tanto no mosto como no leite de leveduras, com freqüências de $53,86 \%$ e $41,18 \%$, respectivamente.

Dos 7 gêneros detectados na presente pesquisa (Saccharomyces, Candida, Torulopsis, Pichia, Schizosaccharomyces, Trichosporon e Rhodotorula), o gênero Saccharomyces foi dominante nas 3 unidades industriais analisadas, com freqüências de $65,47 \%$ na Usina da Pedra, 58,2\% na Usina Santa Elisa e 61,76\% na Destilaria Mandú. $O$ gênero Candida apresentou freqüências de $19,59 \%$ na Usina da Pedra, 3,62\% na Usina Santa Elisa e 32,36\% na Destilaria Mandú, enquanto o gênero Torulopsis apresentou freqüências de 4,08\%, $21,86 \%$ e $4,41 \%$, respectivamente nas mesmas unidades industriais. $\mathrm{O}$ gênero Pichia foi detectado com freqüências de 5,46\% na Usina da Pedra e 9,06\% na Usina Santa Elisa, estando ausente na Destilaria Mandú. $O$ gênero Schizosaccharomyces somente foi detectado na Usina da Pedra, com freqüência de $2,7 \%$, enquanto o gênero Trichosporon somente esteve presente na Usina Santa Elisa, com freqüência de 3,63\%. Finalmente, o gênero Rhodotorula foi detectado exclusivamente na Destilaria Mandú, com freqüência de $1,47 \%$. 


\title{
YEAST IDENTIFICATION IN THE ALCOHOL FERMENTATION PROCESS
}

\author{
Author: KÁTIA TERESINHA CABRINI \\ Adviser: Prof. CLÁUDIO ROSA GALLO
}

\section{SUMMARY}

The aim of this research was to make an evaluation of yeast species variety present in the process of fermentation in alcohol production. Yield identification was carried out during a semester in the harvest of 94/95 in three sugar cane industry units of the State of São Paulo (Usina da Pedra, Usina Santa Elisa and Destilaria Mandú). Samples of primary juice, must and yeast cream were monthly collected in these industry units.

Isolated yield identification from the above samples were carried out according to numerical taxonomy proposed by Griffiths (1981), based mainly on biochemical tests of carbon source assimilation and fermentation.

Two hundred and twenty-five (225) yeasts were isolated and 195 could be identified by the proposed methodology.

Twenty-six (26) yeast species belonged to 7 genera were identified among the three industry units studied. They are: Saccharomyces 
cerevisiae: S. uvarum (S. cerevisiae), S. coreanus (S. cerevisiae), $S$. bayanus, S. chevalieri (S. cerevisiae), S. globosus (S. cerevisiae), S. beticus (S. cerevisiae), S. capensis (S. cerevisiae), S. pretoriensis (Torulaspora pretoriensis), Candida entomophila, C. membranaefaciens, C. rugosa, C. parapsilosis, C. rhagii, C. krusei: Torulopsis castellii (Candida castellii), Torulopsis dattila (Kluyveromyces thermotolerans), T. haemulonii (Candida haemulonii), T. inconspicua (Candida inconspicua), Pichia membranaefaciens, $P$. guilliermondii, $P$. ohmeri, $P$. etchellsii, $P$. spartinae, P. terricola (Issatchenkia terricola), Schizosaccharomyces pombe, Trichosporon brassicae and Rhodotorula glutinis. The yeasts between parentheses correspond to the species updating according to Barnett et al. (1983); Barnett et al. (1990) and Kreger-van Rij (1984).

The Saccharomyces cerevisiae species: $S$. uvarum (S. cerevisiae) was the dominant yeast present in all industry units studied. It showed frequencies of $34,95 \%$ in Usina da Pedra, 32,79\% in Usina Santa Elisa and 35,3\% in Destilaria Mandú.

In Usina da Pedra, the Candida entomophila species was the dominant yeast in the primary juice with a frequency of $30 \%$, while the Saccharomyces cerevisiae species: $S$. uvarum (S. cerevisiae) was dominant in the must as well as in the yeast cream, with frequencies of $42,86 \%$ and $50 \%$, respectively.

In Usina Santa Elisa, the Torulopsis dattila (Kluyveromyces thermotolerans) species was the dominant yeast in the primary juice as well as in the must, with frequencies of $31,25 \%$ and $26,6 \%$, respectively, while in the yeast cream, the Saccharomyces cerevisiae species: $S$. uvarum ( $S$. cerevisiae) was the dominant species, with a frequency of $45,96 \%$. 
The result obtained in Usina da Pedra, showing Candida entomophila species as the dominant species in the primary juice, was also obtained in Destilaria Mandú, with a frequency of $60 \%$. The Saccharomyces cerevisiae species: $S$. uvarum (S. cerevisiae) was dominant in the must as well as in the yeast cream, with frequencies of $53,86 \%$ and $41,18 \%$, respectively.

From the 7 genera detected in this research (Saccharomyces, Candida, Torulopsis, Pichia, Schizosaccharomyces, Trichosporon and Rhodotorula), the Saccharomyces genus was dominant in the 3 industry units studied, with frequencies of $65,47 \%$ in Usina da Pedra, $58,2 \%$ in Usina Santa Elisa and $61,76 \%$ in Destilaria Mandú. The Candida genus showed frequencies of $19,59 \%$ in Usina da Pedra, 3,62\% in Usina Santa Elisa and $32,36 \%$ in Destilaria Mandú, while the Torulopsis genus showed frequencies of $4,08 \%, 21,86 \%$ and $4,41 \%$, respectively. The Pichia genus was detected with frequencies of $5,46 \%$ in Usina da Pedra and $9,06 \%$ in Usina Santa Elisa, and absent in Destilaria Mandú. The Schizosaccharomyces genus was only detected in Usina da Pedra, with a frequency of $2,7 \%$, while the Trichosporon genus was only present in Usina Santa Elisa, with a frequency of 3,63\%. Finally, the Rhodotorula genus was exclusively detected in Destilaria Mandú, with a frequency of $1,47 \%$. 


\section{INTRODUÇÃO}

O caldo de cana se constitui em ótimo substrato para o desenvolvimento de microrganismos, face aos teores de nutrientes orgânicos e inorgânicos que apresenta, alta atividade de água, $\mathrm{pH}$ e temperatura favoráveis. Assim, uma grande variedade de microrganismos encontra-se normalmente presente no mosto utilizado como matéria-prima para a produção de açúcar e álcool. Além disto, fatores como variações nas formas de colheita, terrenos muito variados, diferentes variedades de cana, condições climáticas muito oscilantes, pragas e doenças, tipo de transporte, armazenamento, tempo decorrido entre o corte da cana e o seu processamento na indústria, estado da matéria-prima ao dar entrada na indústria (limpa, suja, molhada, seca, queimada, nova, velha, deteriorada, com raízes, perfuradas por insetos), contribuem significativamente no número de microrganismos na cana-de-açúcar (Silva ${ }^{1}$, citado por Gallo, 1992).

Particularmente, no que se refere à presença de leveduras no processo fermentativo é importante salientar que, excetuando-se aquelas escolhidas para a produção de álcool, todas as demais leveduras encontradas ao longo do processo são consideradas como leveduras contaminantes.

\footnotetext{
${ }^{1}$ S-ILVA, M.H. Control de inversión en el jugo del molino. Sugar y Azucar, v.69, n.8, p.41-43, 1974.
} 
A presença de leveduras contaminantes tem trazido sérios problemas para a fermentação, tanto na produção de vinhos como na fabricação de cerveja, assim como na produção de fermento prensado para panificação. Estes contaminantes podem trazer problemas graves no que se refere ao processo fermentativo e, principalmente, à deterioração do produto final, provocando o aparecimento de sabores e aromas que descaracterizam totalmente a bebida. Na produção de álcool a partir de melaço e/ou caldo de cana-de-açúcar, a presença de leveduras contaminantes tem sido pouco ou raramente mencionada. A proporção destas leveduras em relação a levedura de processo tem variado bastante, desde algumas células até quase a total dominância. A origem destas leveduras contaminantes é variável, destacandose como principais o melaço, o xarope, a água de lavagem da cana e o próprio solo. Estas leveduras podem chegar às dornas de fermentação tanto na forma vegetativa como na de esporos. A predominância de uma ou de outra forma vai depender do tipo de processo empregado pela indústria, ou seja, com ou sem tratamento do caldo (aquecimento, decantação, concentração, etc.). Os efeitos negativos da presença de leveduras contaminantes na fermentação alcoólica podem ser sentidos pela redução do rendimento da fermentação, maior tempo de fermentação, maior formação de espumas, etc. A maior ou menor intensidade destes efeitos vai depender das características fisiológicas da levedura contaminante, ou seja, se Saccharomyces ou não Saccharomyces (Amorim et al., 1989).

Contudo, leveduras contaminantes podem, ao contrário dos efeitos prejudiciais citados anteriormente, apresentar bom desempenho ao longo do processo fermentativo e, desta forma, serem selecionadas para a utilização em novos processos de fermentação. 


\section{OBJETIVO}

Este trabalho teve como objetivo identificar as leveduras presentes em processos de produção de álcool durante 1 semestre da safra 94/95 em 3 unidades industriais, utilizando-se amostras de caldo primário, mosto e leite de leveduras, a fim de se obter um levantamento da variedade de espécies de leveduras ao longo destes processos.

Assim sendo, espera-se que os dados fornecidos pelo trabalho contribuam para a melhoria dos processos fermentativos e que posssam também, enriquecer a literatura existente sobre o assunto, uma vez que, pouquíssimas informações sobre leveduras contaminantes na produção de álcool tem sido publicadas. 


\section{REVISÃO DE LITERATURA}

\subsection{Contaminação microbiana}

Todo desenvolvimento de microrganismos indesejáveis à fermentação constitui-se em contaminação, fato comum nas usinas/destilarias devido principalmente à falta de assepsia durante o processo e à carga microbiana que acompanha a matéria-prima até a indústria.

Para Amorim \& Oliveira (1982), a contaminação caracteriza-se quando o número de microrganismos, que não seja a levedura selecionada, atinge níveis que são prejudiciais à produção de álcool. A diminuição da produção de álcool pode ser causada por diversos motivos, tais como consumo de açúcar pelo microrganismo contaminante (praticamente todo microrganismo consome açúcar), consumo de álcool produzido, morte ou inibição de células de leveduras por toxinas ou outras substâncias lançadas ao meio pelo microrganismo contaminante, ou pelo excesso de ácido ou outro produto utilizado para combater a contaminação.

Os mesmos autores mencionam que a ocorrência simultânea destes fatores ocasiona um prejuízo ainda maior à fermentação e que além dos 
prejuízos diretos, existem os indiretos, pois quando uma contaminação violenta se instala, o tempo de fermentação normalmente fica mais longo. Conseqüentemente, há uma diminuição do ritmo da destilação e da moagem e, portanto, do corte de cana, uma vez que a perda de açúcar no campo ou no pátio da indústria em canas armazenadas por muitas horas é fato consumado. Quanto maior a umidade do ar e a temperatura ambiente, maior a perda de açúcar e maior a quantidade de microrganismos que esta cana levará para a indústria. Finalmente, enfatizam que em algumas ocasiões a contaminação é tão violenta que a fermentação acaba por completo, sendo preciso iniciar tudo novamente.

A origem dos contaminantes da fermentação alcoólica segundo Stupiello \& Horii (1981), é o solo, podendo aumentar sensivelmente o número dos mesmos durante o período que decorre da queima, corte, transporte, armazenamento, até o processo de moagem. A cana se transforma em excelente meio de cultivo e muitos microrganismos do solo encontram amplas e favoráveis condições de desenvolvimento, levando à obtenção de um caldo misto altamente contaminado e sensivelmente exaurido em açúcares em relação ao teor original.

Também, Bovi \& Marques (1983), citam a terra que acompanha a matéria-prima do campo, como fonte de microrganismos contaminantes. Além disto, complementam que em estágios mais avançados de deterioração, tais microrganismos podem estar presentes nas partes internas da cana em quantidades suficientes para promover alterações na sua composição. Ainda, segundo os autores, as águas industriais tais como água de lavagem da cana, água de preparo do pé-de-cuba e água para limpeza dos equipamentos, constituem pontos de entrada de microrganismos no processo. 
Microrganismos contaminantes podem também ser habitantes naturais da planta, da matéria orgânica em decomposição, além de estarem associados às pragas e moléstias da cultura (Yokoya, 1991).

A flora epífita da cana-de-açúcar também é citada como fonte de microrganismos por Stupiello (1982), que destaca ainda, os equipamentos de corte como inoculadores de contaminantes no processo.

Portanto, a qualidade microbiológica da cana-de-açúcar é fundamental na obtenção de rendimentos industriais satisfatórios, sendo determinada pela quantidade e características dos microrganismos presentes, bem como pelos produtos de suas atividades, regulados pela interação variedade-climamicrorganismos (Stupiello, 1981).

As rachaduras provocadas pelo crescimento do colmo da cana, constituem em excelentes sítios de multiplicação de microrganismos segundo Bevan \& Bond (1971), que também explicam que a remoção da cera que envolve o colmo pela ação do calor produzido com a queima, permite que os microrganismos presentes cresçam livremente, utilizando como meio, o caldo exsudado.

Os produtos do metabolismo de microrganismos são incorporados ao caldo, encontrando-se substâncias como álcoois, ácidos orgânicos e polissacarídeos, que alteram a sua composição química (Cooperativa Central dos Produtores de Açúcar e Álcool do Estado de São Paulo - COPERSUCAR, 1983a). 
Também, subprodutos da fabricação do açúcar quando utilizados como matéria-prima para obtenção de álcool, podem contribuir para o aumento dos contaminantes no processo fermentativo.

Assim, o grau de contaminação do mosto depende dos componentes que o formam. Proporções e condições microbiológicas do caldo, xarope e melaço, são essenciais na composição da flora do mosto (COPERSUCAR, 1983b).

Toma-se, então, fundamental o controle do desenvolvimento de microrganismos no processo de fermentação, visando proporcionar condições favoráveis às leveduras do processo para que estas atuem o mais próximo possível do seu limite máximo de eficiência nos ciclos fermentativos. Para tanto, algumas medidas devem ser tomadas, tais como industrialização da matériaprima com menor tempo possível de pós-colheita, lavagem da cana-de-açúcar com água em quantidade suficiente e qualidade satisfatória, tratamento térmico do caldo em processo, assepsia dos equipamentos, adequação nutricional do meio às necessidades das leveduras, controle da temperatura da fermentação, acompanhamento e controle da carga microbiana existente no processo (Bovi \& Marques, 1983).

\subsection{Agentes de fermentação alcoólica}

As leveduras são os microrganismos responsáveis pela fermentação alcoólica, ou seja, pela transformação de açúcares presentes no mosto em etanol 
e dióxido de carbono, como produtos principais desta transformação (Germek, 1978; Lourencini, 1990; Rasovsky, 1973).

Para Silvà (1994), a eleição de microrganismos é de vital importância para a qualidade e a quantidade de metabólitos primários como etanol e dióxido de carbono que deverão ser obtidos no final da fermentação, pois trata-se de um processo químico decorrente da atividade de microrganismos que agem sobre diversos substratos orgânicos, alterando-os e originando a formação de outras substâncias.

As leveduras alcoólicas devem apresentar características específicas para seu uso industrial, entre as quais boa produtividade, tolerância ao álcool, osmotolerância, resistência à acidez elevada e à variações de temperatura, fácil propagação, capacidade de utilização de uma ampla variedade de substratos, resistência a certos resíduos tóxicos, mínima geração de calor durante a fermentação e finalmente, possuir características uniformes e estáveis durante a fermentação, a fim de preservar as características anteriormente citadas (Camhi, 1979; Ferrari et al., 1980; Germek, 1978; Maiorella, 1985; Panchal \& Tavares, s.d.). Porém, nenhuma linhagem atualmente empregada nos processos industriais para obtenção de etanol possui todas as características mencionadas anteriormente, daí as contínuas pesquisas realizadas nesta área.

Segundo Franco (1978), as leveduras mais utilizadas na fermentação alcoólica são Saccharomyces cerevisiae e S. uvarum IZ-1904, sendo a primeira a mais empregada em razão de sua fácil obtenção, pois é utilizada no fermento do pão, consumido na panificação industrial. Estas mesmas leveduras são também indicadas por Lima (1975), para a produção de álcool e aguardentes. 
Na produção de etanol, Gutierrez (1994), cita a utilização de linhagens de Saccharomyces, Schizosaccharomyces e Kluyveromyces, prevalecendo no Brasil, o emprego de linhagens de Saccharomyces cerevisiae como a M-300A, S. uvarum IZ-1904 e fermento prensado de panificação ("Fleischmann" e "Itaiquara").

Camhi (1979), recomenda ser mais vantajoso utilizar culturas mistas de leveduras, destacando as mais adequadas: Saccharomyces cerevisiae, $S$. ellipsoideus, S. anamensis e Schizosaccharomyces pombe.

Segundo Basso et al. (1995), uma mistura de leveduras designadas por "CR" (Usina Cresciumal), "SA" (Usina Santa Adélia) e "JA" (Destilaria Jardest), onde a primeira corresponde à Saccharomyces bayanus e as duas últimas à $S$. cerevisiae, foi utilizada para iniciar o processo de produção de álcool em várias unidades industriais na safra de 94/95, sendo tais leveduras isoladas de processos anteriores.

Na safra de 95/96, Basso et al. (1996), relatam também a utilização, em várias unidades industriais, de uma mistura de leveduras para iniciar o processo fermentativo. A mistura foi composta pelas leveduras "SA" (Usina Santa Adélia), "VR-1" (Usina Vale do Rosário) e "PE-2" ou "PE-5" (Usina da Pedra), sendo que as leveduras designadas por "SA", "VR-1" e "PE-2", correspondem à Saccharomyces cerevisiae, enquanto a "PE-5", corresponde à $S$. chevalieri, todas isoladas também de processos anteriores. 


\subsection{Leveduras contaminantes da fermentação alcoólica}

Leveduras estranhas ao processo fermentativo, em geral pertencentes a certa espécie, que ocorrem em proporções elevadas chegando inclusive a sobrenumerar o fermento original e que levam à redução da produtividade e rendimentos, além de problemas operacionais, decantação do fermento, entupimento de boquilhas de separadoras centrifugas, maior formação de espuma, etc., constituem as chamadas leveduras contaminantes (Tavares, 1992).

Porém, qualquer levedura presente no processo que não seja a levedura escolhida para a produção de álcool, ainda que tal levedura não acarrete prejuízos operacionais e de rendimentos à fermentação, é dita como contaminante.

Leveduras contaminantes podem sobrenumerar o fermento em poucos dias, já no início da safra, devido a alguns fatores como: agressividade na competição por nutrientes, maior velocidade de multiplicação, pressão de seleção favorável e proporção inicial significativa. Estes fatores ainda são pouco conhecidos para casos específicos (Tavares, 1992).

As pesquisas aplicadas à fermentação etanólica tem-se concentrado, preferencialmente, em problemas relativos à contaminações bacterianas, permanecendo as contaminações por leveduras pouco conhecidas e estudadas (Oliveira, 1987).

Leveduras dos gêneros Saccharomyces, Torula e Pichia, foram isoladas de canas verdes por Bevan \& Bond (1971), que também identificaram leveduras dos gêneros Rhodotorula, Candida e, novamente Torula, da 
superficie de canas com mais de 24 horas após a queima. No caldo misto, os autores citam a presença de leveduras contaminantes termofilicas metabolizadoras de amido.

Neder (1957), em trabalho realizado com caldo de cana e mosto em fermentação para fabricação de aguardente, isolou 261 culturas de leveduras pertencentes aos gêneros Saccharomyces, Candida e Pichia. No gênero Saccharomyces foram identificadas as seguintes espécies: $S$. cerevisiae, $S$. cerevisiae var. ellipsoideus, S. carlsbergensis, S. marxianus, S. fructuum, $S$. exiguus, $S$. fermentati e $S$. chevalieri. O gênero Candida apresentou as espécies: $C$. krusei, C. guilliermondii, $C$. macedoniensis, C. mycoderma e $C$. tropicalis. Pichia membranaefaciens foi a espécie pertencente ao gênero Pichia. O trabalho pôde ainda, demonstrar a predominância do gênero Saccharomyces $(51,5 \%)$ em relação aos gêneros Candida (47,3\%) e Pichia $(1,2 \%)$, sendo que no gênero Saccharomyces a espécie $S$. cerevisiae apresentou freqüência dominante, com uma porcentagem de 71,6 e no gênero Candida predominou a espécie $C$. krusei com uma porcentagem de 58,1.

Leveduras presentes na fabricação de aguardente, também foram pesquisadas por Shehata (1960), utilizando igualmente amostras de caldo de cana e mosto em fermentação, além de amostras da água de lavagem da cana. Um total de 139 culturas de leveduras foram isoladas e 26 espécies foram identificadas, das quais 8 predominaram no caldo, sendo elas: Saccharomyces carlsbergensis var. alcoholophila, S. cerevisiae, Pichia membranaefaciens, $P$. fermentans, Candida krusei, C. guilliermondii, C. intermedia var. ethanophila e Torulopsis stellata. Já, no mosto em fermentação, apenas as espécies 
Saccharomyces carlsbergensis var. alcoholophila, S. cerevisiae e Schizosaccharomyces pombe, apresentaram-se como predominantes. O autor justifica que a maior variedade de leveduras no caldo pode estar relacionada à partículas de solo presentes na cana, enquanto que a predominância das leveduras no mosto pode ser atribuída ao poder fermentativo ou a tolerância à altas temperaturas por parte de tais leveduras. Outras espécies de leveduras identificadas, porém com baixas freqüências, aparecendo principalmente no caldo foram: Candida mycoderma, C. parapsilosis var. intermedia, C. tropicalis, C. saccharum, Endomyces magnusii, Hansenula anomala, Kloeckera apiculata, Saccharomyces acidifaciens, S. chevalieri, S. marxianus, S. microellipsodes, S. rosei, Saccharomycodes ludwigii, Torulopsis glabrata, T. globosa, T. stellata var. cambresieri, T. saccharum.

Candida diddensiae, C. fabianii, C. intermedia, C. santamariae, Cryptococcus kuetzingii, Hansenula polymorpha, Kloeckera corticis, Rhodotorula pallida, R. rubra, Saccharomyces uvarum, Torulopsis norvegica e Trichosporon cutaneum foram as leveduras identificadas por Lima et al. (1974), analisando amostras de caldo bruto, caldo misto e água de embebição em usina de açúcar de cana.

A análise morfológica de colônias de leveduras provenientes de amostras de caldo primário e mosto realizada por Souza et al. (1994), permitiu a caracterização de 9 biotipos diferentes, dos quais apenas 1 se enquadrou no gênero Saccharomyces, após avaliação em meios de cultivo seletivos.

Também, a utilização de meios seletivos permitiu a identificação das espécies Hansenula anomala, Candida famata, Saccharomyces kluyveri e $S$. 
cerevisiae como leveduras contaminantes em uma unidade industrial a partir de amostras de fermento centrifugado, fermento tratado e mosto em fermentação (Oliveira \& Pagnocica, 1988).

Miniac (1989), cita a espécie Brettanomyces intermedius como contaminante em várias destilarias na França, sendo a mesma, responsável pela redução da produção de etanol e pelo aumento da acidez orgânica, levando inevitavelmente, à necessidade de renovação de todo o fermento em processo.

Uma linhagem de Saccharomyces cerevisiae formada por cadeias multicelulares ramificadas, foi identificada por Oliveira \& Silva (1993), na produção de etanol e, segundo as autoras, tal linhagem apresentou elevado poder competitivo com a levedura usual de processo e com as demais leveduras contaminantes encontradas.

Silva (1994), em pesquisa sobre leveduras contaminantes na produção de etanol industrial, constatou que a espécie Dekkera bruxellensis apresentou-se como a levedura contaminante de maior incidência e relevância pelo poder competitivo e conseqüências adversas ao processo de obtenção de etanol. Com relação ao poder competitivo de Dekkera bruxellensis, a autora demonstra sua evolução populacional de aproximadamente $62 \%$ para $96 \%$ do número total de leveduras em 8 dias de operação, culminando com a necessidade de renovação do fermento.

Além de Dekkera bruxellensis (Brettanomyces bruxellensis), o monitoramento microbiológico realizado por Silva (1994), permitiu identificar de 242 isolados, as espécies de leveduras: Candida maltosa, C. mogii, Issatchenkia occidentalis (Candida sorbosa), Rhodotorula 
minuta/mucilaginosa, Saccharomyces cerevisiae, S. chevalieri, S. uvarum, Schizosaccharomyces pombe e Torulaspora delbrueckii (Candida colliculosa).

A presença de levedura contaminante na produção de álcool, a qual provocou sérios problemas ao processo fermentativo, foi relatada por Amorim et al. (1989). Segundo os autores, uma característica peculiar das células desta levedura era a formação de cachos, pois as células-filhas não se soltavam da célula-mãe. Esta levedura foi encontrada no caldo, na água de refrigeração das dornas e na vinhaça. A identificação deste contaminante demonstrou tratar-se da espécie Candida krusei.

Na safra de 88/89, 2 casos de contaminação por leveduras com sérios problemas para o processo fermentativo, como aumento do tempo de fermentação e diminuição do rendimento, foram também citados por Amorim et al. (1989). Em ambos os casos, houve completa dominância da levedura contaminante no processo, sendo que a mesma resistia ao tratamento térmico do caldo, cuja temperatura de aquecimento era igual ou inferior a $100^{\circ} \mathrm{C}$. Foi necessário trocar todo o fermento em processo e elevar a temperatura de aquecimento do caldo para $105-110^{\circ} \mathrm{C}$ para resolver o problema. Novamente a espécie Candida krusei foi identificada como contaminante, apesar de tratar-se de uma linhagem diferente da citada anteriormente.

Em outro trabalho, 3 leveduras contaminantes isoladas do mosto e do vinho de uma unidade industrial, não foram responsáveis pela redução do rendimento da fermentação alcoólica. Tal resultado foi comprovado através de ensaios fermentativos, comparando-se as leveduras contaminantes com uma levedura de processo (Amorim et al., 1991). 
Basso et al. (1992), pesquisando a permanência de leveduras melhoradas geneticamente no processo fermentativo durante a safra de 91/92 em uma usina sucro-alcooleira, constataram que as linhagens melhoradas não conseguiram competir com aquelas existentes no ambiente industrial e que, portanto, as leveduras contaminantes dominaram o processo. Segundo os autores, tais leveduras contaminantes deveriam exibir maior resistência aos agentes estressantes em condições industriais e ainda, apresentar boa eficiência fermentativa.

Durante a safra de 92/93, Basso et al. (1993), pesquisaram novamente a estabilidade das leveduras nas dornas de fermentação analisando, basicamente, amostras de fermento coletadas ao longo da safra. Das 6 usinas/destilarias acompanhadas, apenas uma, a qual iniciou o processo com fermento próprio, permaneceu com o mesmo fermento ao longo da safra; nas outras 5 unidades industriais, contudo, os fermentos iniciais utilizados ("TA": M-300A ou "Fleischmann") foram dominados por outras leveduras. Tal acompanhamento abrangeu testes de separação do DNA cromossômico, bem como testes de assimilação e fermentação de fontes de carbono, além de observações de características macro e micromorfológicas das colônias de leveduras, cujos resultados apresentaram-se coerentes entre si. Algumas espécies de leveduras puderam ainda, serem identificadas como ocorreu em uma das unidades industriais, onde Saccharomyces cerevisiae e $S$. chevalieri apresentaram-se como as contaminantes dominantes, seguidas por $S$. coreanus que se apresentou na proporção de até $10 \%$ e Torulopsis apis, na proporção de 1\%. Também, em outra unidade industrial, Saccharomyces cerevisiae mostrou-se como a levedura 
contaminante dominante tanto nas amostras de vinho bruto como nas de mel analisadas, aparecendo ainda, Pichia membranaefaciens numa proporção inferior a $1 \%$ no vinho e Candida macedoniensis na proporção de $10 \%$ no mel.

Já, durante a safra de 93/94, Basso et al. (1994), pesquisaram um maior número de unidades industriais em relação à safra anterior. Dentre as leveduras iniciais utilizadas, principalmente a "JA" (Destilaria Jardest), "TA", "Fleischmann" e "Itaiquara", a levedura "JA", que corresponde à Saccharomyces cerevisiae, mostrou maior habilidade de permanência no processo, sendo que o aparecimento de leveduras contaminantes variou com a usina/destilaria em questão. As leveduras contaminantes normalmente se constituíram de diferentes Saccharomyces, algumas mostrando-se como dominantes, outras como persistentes ao longo do processo. Com menor freqüência se observou leveduras não Saccharomyces, porém sem permanência no processo. A espécie Candida krusei foi relatada como sendo uma das não Saccharomyces contaminantes.

A mistura de leveduras utilizada para iniciar o processo fermentativo na maioria das unidades industriais acompanhadas por Basso et al. (1995), durante a safra de 94/95, mostrou-se com maior permanência no processo em relação aos fermentos "Fleischmann" e "Itaiquara". Tal mistura foi composta pelas leveduras "CR" (Usina Cresciumal), "SA" (Usina Santa Adélia) e "JA" (Destilaria Jardest), a primeira correspondendo à Saccharomyces bayanus e as duas últimas à $S$. cerevisiae, selecionadas de safras anteriores. Este resultado vem demonstrar a maior adaptação ao processo, por parte das leveduras selecionadas. Igualmente como os resultados da pesquisa anterior, os 
contaminantes se constituíram basicamente em leveduras do gênero Saccharomyces .

Resultado semelhante foi obtido durante a safra de 95/96, em trabalho realizado por Basso et al. (1996), que acompanharam várias unidades industriais, as quais utilizaram para o início do processo de fermentação alcoólica a mistura das leveduras "SA" (Usina Santa Adélia), "VR-1" (Usina Vale do Rosário) e "PE-2" ou "PE-5" (Usina da Pedra), onde as leveduras designadas por "SA", "VR-1" e "PE-2", correspondem à Saccharomyces cerevisiae, enquanto que a "PE-5", corresponde à $S$. chevalieri. Os autores observaram ainda, que a levedura "SA" foi a mais rapidamente substituída e ausente no final da safra em quase todas as unidades industriais, ao contrário das leveduras "VR-1" e "PE-2" que apresentaram excelentes persistência e dominância no processo, destacando-se sobremaneira a "PE-2". Também, convém ressaltar a presença da espécie Candida krusei em uma das unidades industriais logo no início do processo, porém sem persistência ao longo do mesmo.

Oliveira et al. (1996), citam outras leveduras contaminantes identificadas através de testes de assimilação e fermentação de carboidratos durante as safras 91/92 a 95/96, sendo elas: Saccharomyces capensis, $S$. bayanus, Pichia ohmeri, Trichosporon brassicae, Torulaspora pretoriensis e Klugveromyces vanudenii.

Leveduras dos gêneros: Saccharomyces, Torulaspora, Pichia, Candida, Kloeckera, Hansenula, Saccharomycodes, Hanseniaspora, Cryptococcus, Rhodotorula, Torulopsis, Metschnikowia, Issatchenkia, 
Kluyveromyces, Debaryomyces, Zygosaccharomyces, Dekkera, Brettanomyces, são encontradas em processos fermentativos para a produção de vinhos, destacando-se espécies como: Saccharomyces cerevisiae, Pichia membranaefaciens, Kloeckera apiculata, Candida krusei, C. pulcherrima, C. stellata, Hansenula anomala, Rhodotorula glutinis, Metschnikowia pulcherrima, Issatchenkia terricola, entre outras (Amerine \& Cruess, 1960; Amerine \& Kunkee, 1968; Fleet et al., 1984; Heard \& Fleet, 1985; Heard \& Fleet, 1986; Kunkee \& Bisson, 1993; Mora et al., 1988; Rosini, 1984; Thomas, 1993; Yanagida et al., 1992).

Os gêneros citados em vinhos, também são contaminantes comuns em cervejaria (Barnett et al., 1983; Hough, 1990; Kleyn \& Hough, 1971) e espécies como Saccharomyces cerevisiae var. ellipsoideus, $S$. pasteurianus, $S$. turbidans, S. diastaticus, Pichia membranaefaciens, Hansenula anomala, Candida krusei, C. vini, C. tropicalis, C. utilis, Rhodotorula mucilaginosa, Torulopsis famata, Brettanomyces bruxellensis, etc., são encontradas (Fowell², citado por Maccioni, 1984; Rainbow, 1970; Reinold, 1995; Thomas, 1993; Thomas, 1996).

${ }^{2}$ FOWELL, R.R. Infection control in yeast factories and breweries. Proc. Biochem., v.2, n.12, p.11-15, 1967. 


\section{MATERIAL E MÉTODOS}

\subsection{Meios de cultivo}

4.1.1 Meio YEPD ágar (Bamett et al., 1983)
Extrato de levedura......................10,0 g
Peptona......................................10,0 g
Dextrose.......................................20,0 g
Ágar..........................................15,0 g
$\mathrm{H}_{2} \mathrm{O}$ destilada................................ $1.000 \mathrm{~mL}$

4.1.2 Meio YEPD caldo (Bamett et al., 1983)

Extrato de levedura........................10,0 g

Peptona.........................................10,0 g

Dextrose....................................20,0 g

$\mathrm{H}_{2} \mathrm{O}$ destilada................................. $1.000 \mathrm{~mL}$ 
4.1.3 Meio basal para assimilação e fermentação de fontes de carbono (Corrêa et al., 1991)

Sulfato de amônio $.5,0 \mathrm{~g}$

Fosfato monobásico de potássio. $1,0 \mathrm{~g}$

Sulfato de magnésio $0,5 \mathrm{~g}$

$\mathrm{H}_{2} \mathrm{O}$ destilada. $1.000 \mathrm{~mL}$

4.1.4 Meio de nitrato de potássio para teste de redução de nitrato à nitrito (Smibert \& Krieg, 1981)

Nitrato de potássio. $1,0 \mathrm{~g}$ Ágar. $1,7 \mathrm{~g}$

YEPD caldo $1.000 \mathrm{~mL}$

4.1.5 Meio YEPD caldo - 50\% glucose para teste de tolerância osmótica (Bamett et al., 1983)
Extrato de levedura $10,0 \mathrm{~g}$
Peptona $10,0 \mathrm{~g}$
Dextrose (glucose) $.500,0 \mathrm{~g}$ $\mathrm{H}_{2} \mathrm{O}$ destilada. $1.000 \mathrm{~mL}$ 
4.1.6 Meio YEPD caldo - $10 \%$ cloreto de sódio $(\mathrm{NaCl})$ para teste de tolerância osmótica (Kreger-van Rij, 1984)

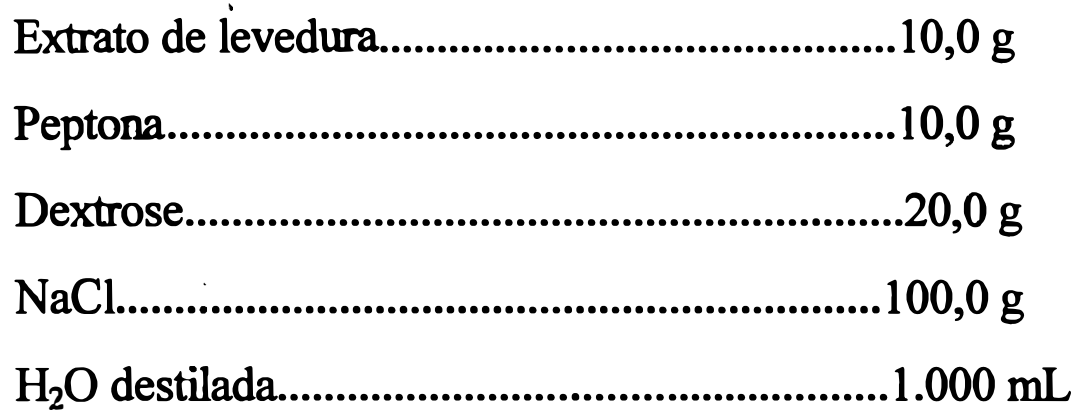

4.1.7 Meio de amido para teste de hidrólise de amido

Extrato de levedura. $10,0 \mathrm{~g}$

Peptona. $10,0 \mathrm{~g}$

Amido. $20,0 \mathrm{~g}$

Ágar $15,0 \mathrm{~g}$

$\mathrm{H}_{2} \mathrm{O}$ destilada. $1.000 \mathrm{~mL}$

\subsection{Soluções}

4.2.1 Solução crioprotetora para liofilização (Arcuri et al., 1988)

Sácarose. $8,0 \mathrm{~g}$

Peptona. $2,0 \mathrm{~g}$

$\mathrm{H}_{2} \mathrm{O}$ destilada. $100 \mathrm{~mL}$ 


\subsubsection{Solução estoque de cloranfenicol}

Cloranfenicol (1 comprimido de Quemicetina)......250,0 mg

$\mathrm{H}_{2} \mathrm{O}$ destilada e esterilizada................................25 mL

Observação: $2,5 \mathrm{~mL}$ da solução estoque foram adicionados em 250 $\mathrm{mL}$ de meio de cultivo YEPD ágar, obtendo-se a dosagem de 100 ppm.

\subsubsection{Solução estoque de tetraciclina}

Tetraciclina $250,0 \mathrm{mg}$

$\mathrm{H}_{2} \mathrm{O}$ destilada e esterilizada. $.25 \mathrm{~mL}$

Observação: $2,5 \mathrm{~mL}$ da solução estoque foram adicionados em 250 $\mathrm{mL}$ de meio de cultivo YEPD ágar, obtendo-se a dosagem de 100 ppm.

4.2.4 Soluções para teste de redução de nitrato à nitrito (Smibert \& Krieg, 1981)

Solução A:

Ácido sulfanilico

$0,8 \mathrm{~g}$

Ácido acético $5 \mathrm{~N}$. $.100 \mathrm{~mL}$

\section{Solução B:}

$\mathrm{N}, \mathrm{N}$ dimetil- $\alpha$-naftilamina $.0,42 \mathrm{~g}$ Ácido acético $5 \mathrm{~N}$. $100 \mathrm{~mL}$ 
4.2.5 Solução de lugol para teste de hidrólise de amido (Bamett et al., 1983)

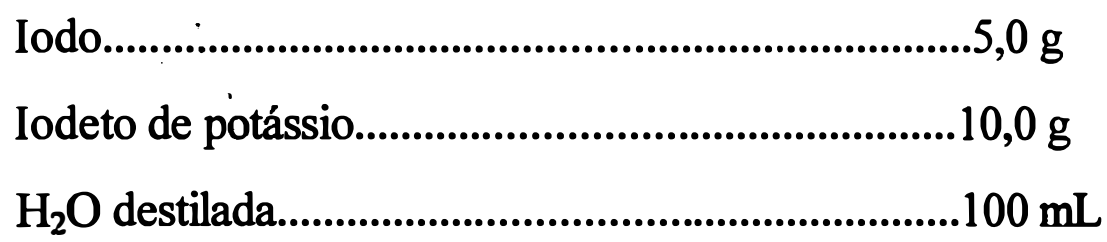

4.3 Esterilização de meios de cultivo, soluções e materiais

4.3.1 Esterilização em autoclave a uma atmosfera de pressão, a $121^{\circ} \mathrm{C}$ durante 15 minutos

meio de cultivo YEPD ágar

meio de cultivo YEPD caldo para reativação, isolamento e purificação

das culturas

meio de cultivo para teste de hidrólise de amido

meio basal testemunha

meio de cultivo para teste de redução de nitrato à nitrito

meio YEPD caldo para teste de crescimento à temperatura de $37^{\circ} \mathrm{C}$

meio YEPD caldo - $50 \%$ glucose e meio YEPD caldo - $10 \% \mathrm{NaCl}$

para teste de tolerância osmótica das células

solução crioprotetora para liofilização

tubos de diluição contendo $9 \mathrm{~mL}$ de $\mathrm{H}_{2} \mathrm{O}$ destilada 
garrafas de diluição, 90-99 mL - Pyrex, contendo $25 \mathrm{~mL}$ de $\mathrm{H}_{2} \mathrm{O}$ destilada para as soluções estoques dos inibidores bacterianos garrafas de diluição, 90-99 mL - Pyrex, para coleta das amostras pipetas Pasteur e ampolas de vidro para liofilização

4.3.2 Esterilização em autoclave a uma atmosfera de pressão, a $121^{\circ} \mathrm{C}$ durante 3 minutos

meio basal acrescido da fonte de carbono a ser testada quanto a assimilação e/ou fermentação

Observação: Este tempo de esterilização foi padronizado para todas as fontes de carbono testadas, uma vez que, várias delas são sensíveis à esterilização por 15 minutos.

\subsubsection{Esterilização em estufa a $180^{\circ} \mathrm{C}$ durante duas horas}

placas de Petri

pipetas

\subsection{Equipamentos}

agitador de tubos automático, Tecnal - TE 162

liofilizador, VIRTIS - Division of Cenco Medical/Health Supply Corp. detetor de vazamento, Edwards Hight Vacuum ST 200K MK II 
microscópio estereoscópico, Bausch \& Lomb

microscópio óptico comum, Olympus BHC

contador de colônias, tipo Quebec

balança analítica, Mettler H 35 AR

balança digital, Marte MOD 200

banho de água termostatizado, Ética 3146

medidor de pH, Digimed DMPH - 2

estufa para esterilização, Fanem MOD 315 SE

estufa para secagem, Fanem MOD 315/3

estufas para incubação, Fanem MOD 002/3

autoclave, Phoenix AV 50

refrigerador

forno microondas

vidrarias em geral

\subsection{Amostras utilizadas para o isolamento de leveduras}

Para o isolamento de leveduras foram utilizadas amostras de caldo primário, mosto e leite de leveduras, provenientes de 3 unidades industriais do Estado de São Paulo, à saber: Usina da Pedra, no município de Serrana, Usina Santa Elisa, no município de Sertãozinho e Destilaria Mandú, no município de Guaíra. As coletas foram realizadas mensalmente durante 1 semestre da safra 94/95. Para compor as amostras de caldo primário (caldo de cana obtido a partir 
do $1^{\circ}$ terno da moenda), alíquotas eram coletadas de duas em duas horas aproximadamente, ao longo de um único dia e, assim, a mistura de tais alíquotas correspondia à amostra mensal enviada ao laboratório. As amostras de mosto e leite de leveduras seguiram o mesmo processo de composição, sendo o mosto coletado no momento da entrada nas domas e o leite de leveduras nas bicas de saída das centrifugas. De cada unidade industrial foram obtidas 18 amostras, correspondendo a 6 de caldo primário, 6 de mosto e 6 de leite de leveduras, totalizando 54 amostras.

\subsection{Coleta, acondicionamento e transporte das amostras}

As amostras foram coletadas em garrafas de diluição, $90-99 \mathrm{~mL}$ Pyrex, com tampas rosqueáveis, previamente esterilizadas, as quais foram acondicionadas em bolsa térmica para que as condições de refrigeração fossem mantidas durante o armazenamento e transporte. Imediatamente após a chegada das amostras no laboratório, as mesmas foram devidamente processadas.

\subsection{Conservação das culturas brutas de leveduras presentes nas amostras}

As amostras de caldo primário, mosto e leite de leveduras contidas nas garrafas de diluição, foram cuidadosamente agitadas a fim de se obter uma perfeita homogeneização das mesmas. Em seguida, utilizando-se alça de platina 
devidamente flambada e resfriada, o conteúdo de cada amostra foi estriado em placas de Petri (100 mm x $20 \mathrm{~mm}$ ) em duplicata, contendo meio de cultivo YEPD ágar esterilizado, acrescido de inibidores bacterianos, cloranfenicol e tetraciclina, ambos na dosagem de 100 ppm cada, objetivando-se, portanto, somente a recuperação de leveduras a partir das amostras. As placas foram, então, incubadas a $28^{\circ} \mathrm{C}+1^{\circ} \mathrm{C}$ durante 24 a 48 horas. Após o crescimento, a massa de leveduras foi raspada com auxilio de alça de platina e inoculada em tubo de ensaio (10 mm x $75 \mathrm{~mm}$ ), contendo $1 \mathrm{~mL}$ de solução crioprotetora esterilizada, sendo homogeneizada através de cuidadosa agitação. Em seguida, utilizando-se de pipetas Pasteur esterilizadas, cada inóculo foi assepticamente transferido para ampolas de vidro esterilizadas, cada uma contendo em seu interior algodão e etiqueta de identificação. As ampolas foram finalmente colocadas no liofilizador, onde permaneceram por 6 horas (Figura 1). Completada a liofilização, as ampolas foram retiradas do aparelho, sendo testadas em relação à eficiente formação de vácuo no interior das mesmas, utilizando-se um detetor de vazamento. As ampolas foram, então, estocadas à temperatura ambiente até que fossem realizados os processos de isolamento, purificação e identificação das leveduras. 


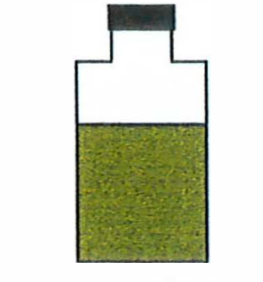

caldo primário
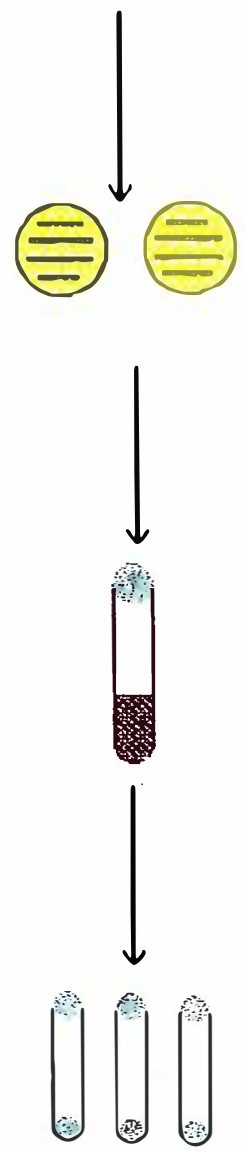

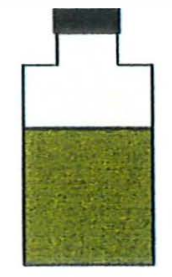

mosto
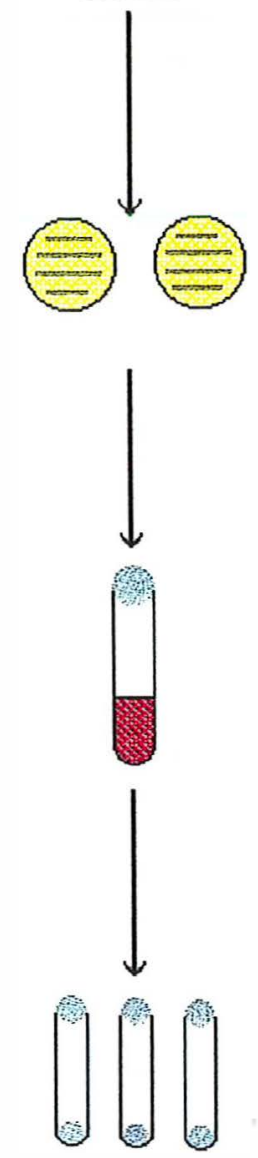

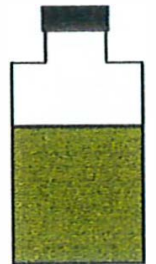

leite de leveduras

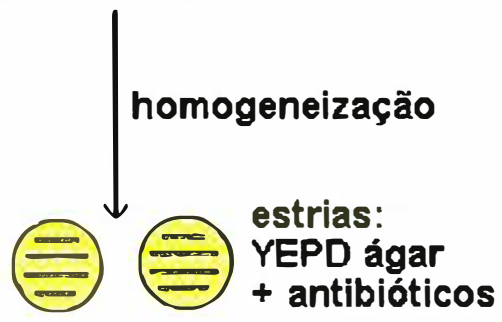

$28^{\circ} \mathrm{C} \pm 1^{\circ} \mathrm{C} / 24-48 \mathrm{~h}$
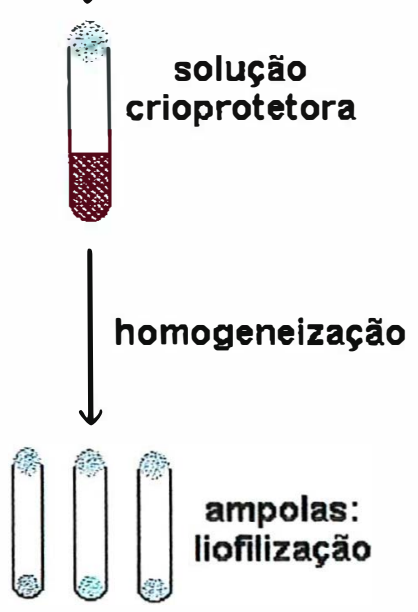

Figura 1 - Esquema para liofilização das culturas brutas de leveduras obtidas a partir das amostras de caldo primário, mosto e leite de leveduras. 


\subsection{Isolamento, purificação e identificação de leveduras}

\subsubsection{Reativação das culturas brutas de leveduras}

As culturas liofilizadas foram reativadas em tubos de cultura (16 mm x $150 \mathrm{~mm}$ ) contendo $5 \mathrm{~mL}$ de caldo YEPD esterilizado e incubadas a $28^{\circ} \mathrm{C} \pm 1^{\circ} \mathrm{C}$ durante 24 horas.

\subsubsection{Isolamento e purificação das culturas de leveduras}

De início, procedeu-se a preparação de diluições em série a partir das culturas reativadas. A menor diluição decimal $\left(10^{-1}\right)$ foi obtida transferindo-se 1 $\mathrm{mL}$ da amostra para 1 tubo de diluição $(16 \mathrm{~mm} \times 150 \mathrm{~mm})$ contendo $9 \mathrm{~mL}$ de $\mathrm{H}_{2} \mathrm{O}$ destilada e esterilizada e assim, sucessivamente, até se obter a maior diluição decimal ưlilizada, ou seja, 10-6. Em seguida, realizou-se o plaqueamento em meio de cultivo YEPD ágar esterilizado (acrescido de 100 ppm de cloranfenicol e $100 \mathrm{ppm}$ de tetraciclina), transferindo-se inóculos de $0,1 \mathrm{~mL}$ das diluições $10^{-4}, 10^{-5}$ e $10^{-6}$ por placa, promovendo-se o espalhamento dos mesmos com espátula de Drigalsky. Também, a partir das amostras puras e das diluições $10^{-1}$, foram realizadas estrias de esgotamento utilizando-se assepticamente uma alça de platina, sendo as placas incubadas a $28^{\circ} \mathrm{C} \pm 1^{\circ} \mathrm{C}$ durante 24 a 48 horas.

Após o crescimento, as colônias foram avaliadas quanto à freqüência e morfologia, sendo que aquelas com características visivelmente distintas ao 
microscópio estereoscópico, foram isoladas em caldo YEPD esterilizado e incubadas a $28^{\circ} \mathrm{C} \pm 1^{\circ} \mathrm{C}$ durante 24 horas. Como na observação ao microscópio estereoscópico das colônias crescidas nas amostras puras e nas das diluições $10^{-1}$ não apareceram colônias diferentes daquelas observadas nas placas das diluições $10^{-4}, 10^{-5}$ e $10^{-6}$, optou-se por utilizar apenas colônias destas 3 últimas diluições, uma vez que, as mesmas encontravam-se mais espalhadas e isoladas nas placas, facilitando a purificação, bem como, por serem as leveduras dominantes nos pontos amostrados.

Após a incubação, as culturas foram assepticamente estriadas em placas de Petri contendo YEPD ágar esterilizado (acrescido de $100 \mathrm{ppm}$ de cloranfenicol e $100 \mathrm{ppm}$ de tetraciclina), a fim de assegurar a pureza das culturas isoladas, sendo as placas incubadas a $28^{\circ} \mathrm{C} \pm 1^{\circ} \mathrm{C}$ durante 24 a 48 horas. Uma vez confirmada tal pureza, as culturas foram inoculadas em caldo YEPD esterilizado e incubadas a $28^{\circ} \mathrm{C} \pm 1^{\circ} \mathrm{C}$ durante 24 horas. Procedeu-se, então, a observação das características de crescimento das culturas em meio líquido, bem como da morfologia e do tamanho celular. Em seguida, inoculou-se cada uma das culturas purificadas em tubos $(16 \mathrm{~mm}$ x $150 \mathrm{~mm})$ contendo YEPD ágar inclinado esterilizado, os quais foram incubados a $28^{\circ} \mathrm{C}+1^{\circ} \mathrm{C}$ durante 24 a 48 horas e, posteriormente, armazenados temporariamente à temperatura ambiente até a aplicação dos testes de identificação das leveduras (Figura 2). 


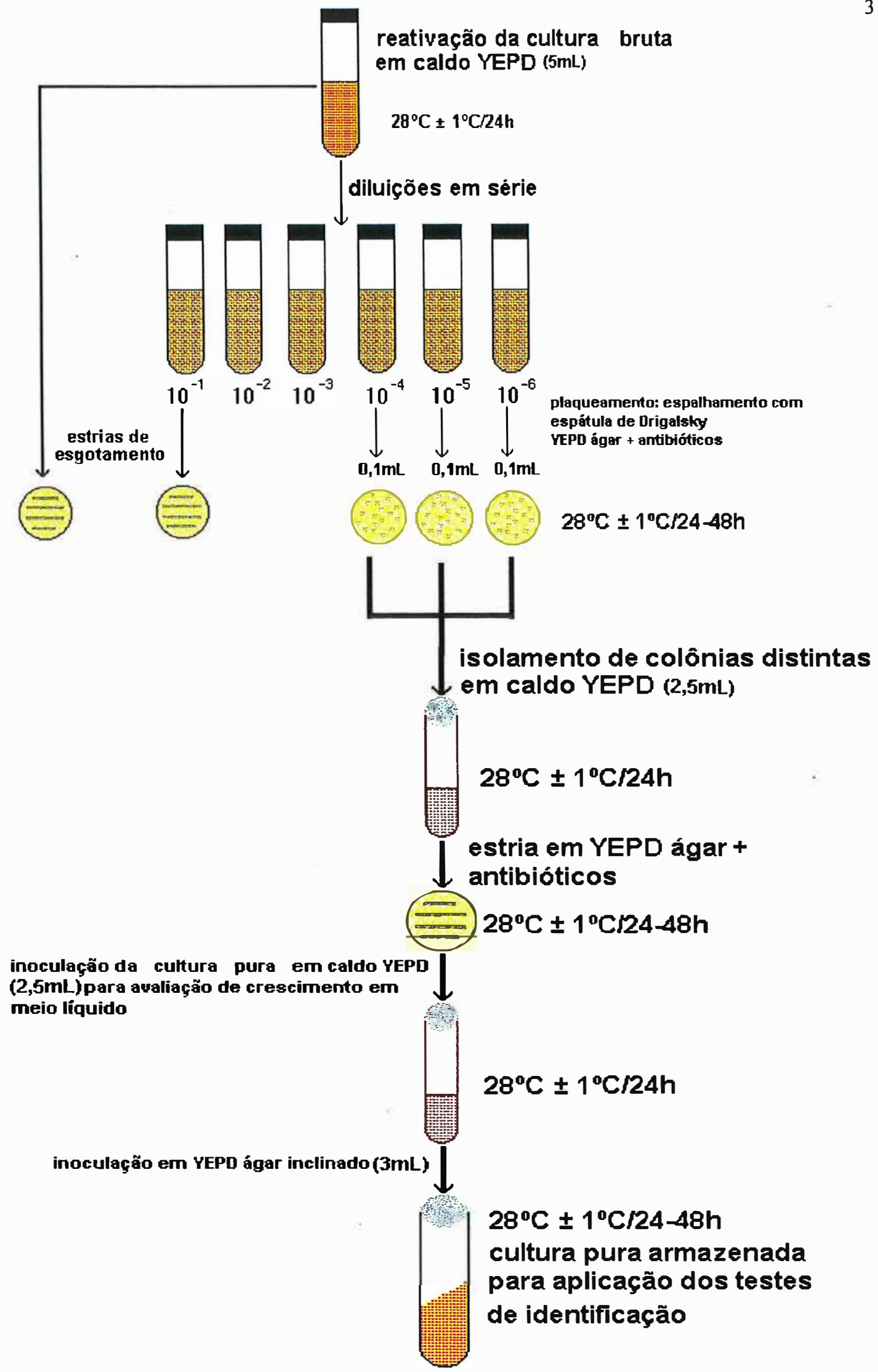

Figura 2 - Esquema para isolamento e purificação de leveduras. 


\subsubsection{Identificação de leveduras}

\subsubsection{Metodologia utilizada na identificação de leveduras}

A identificação das leveduras isoladas foi realizada de acordo com a taxonomia numérica proposta por Griffiths (1981), a qual baseia-se principalmente em testes bioquímicos de assimilação e fermentação de fontes de carbono, atribuindo-lhes valores numéricos específicos dos quais são obtidos códigos numéricos de identificação. A Figura 3 ilustra as características usadas na obtenção dos códigos numéricos para classificação das leveduras.

Como pode ser visto, os valores atribuídos a cada resultado positivo, quando somados de $3 \mathrm{em} 3$ de acordo com as especificações do método, permitem a formação dos dígitos que resultarão em um código numérico. À resultados negativos, devem ser atribuídos valor numérico zero (0). Uma vez obtido um determinado código numérico, este deve ser analisado junto à tabela de códigos numéricos das espécies de leveduras proposta pelo método.

Além dos testes fornecidos pelo método, alguns outros foram ainda acrescentados, sendo eles: assimilação da trealose, L-arabinose, D-ribose e Lramnose e fermentação da maltose, rafinose e melibiose, cujos resultados foram comparados com os manuais de identificação de leveduras: Bamett et al. (1983); Barnett et al. (1990) e Kreger-van Rij (1984). 


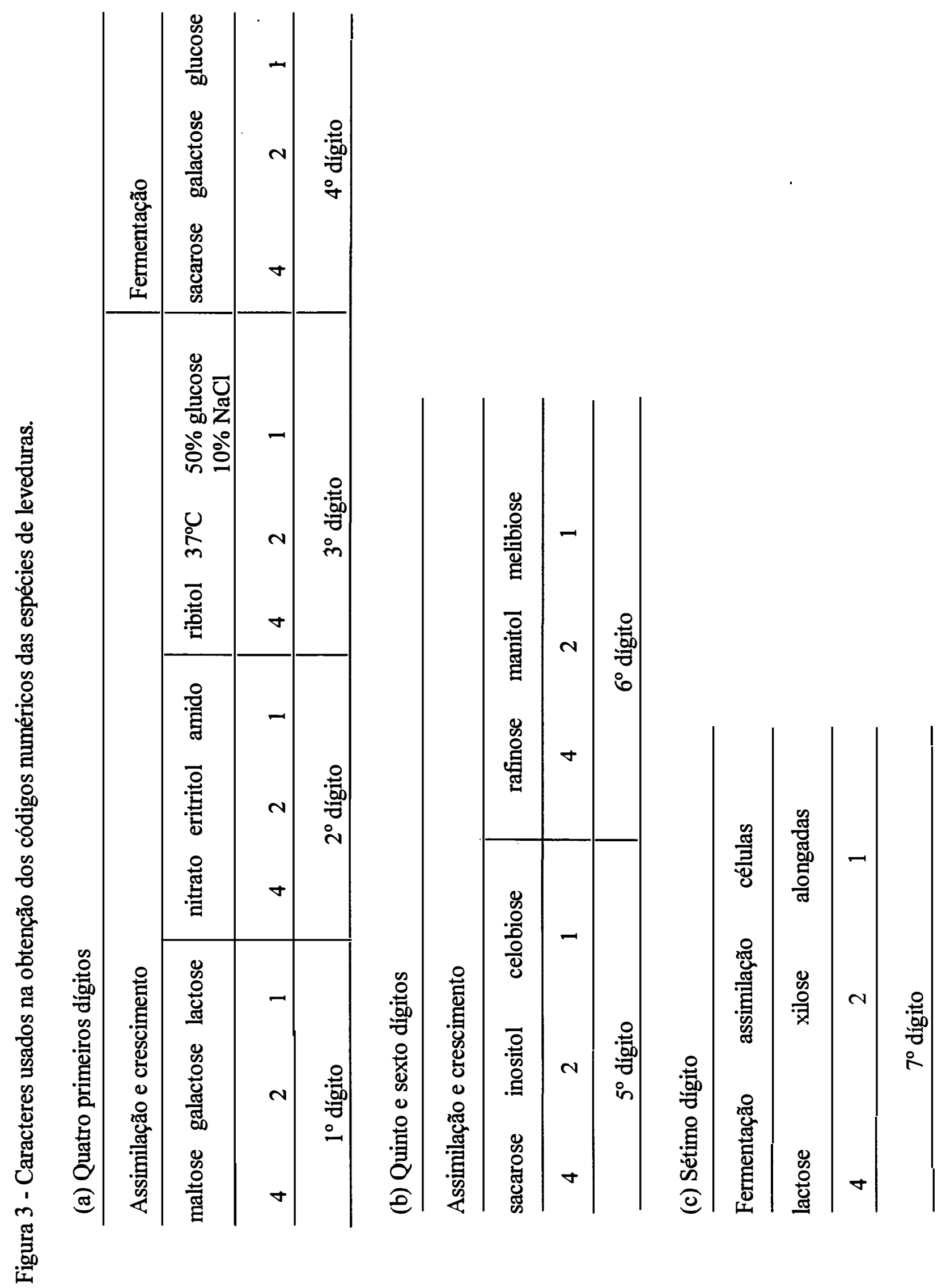


A escolha desta metodologia justifica-se devido à sua praticidade $\mathrm{e}$ facilidade de aplicação à nível industrial, pois utiliza um número reduzido de testes, cujos resultados são obtidos em apenas 3 dias, sendo ainda, um método de fácil condução. Outro aspécto relevante na escolha da metodologia utilizada na presente pesquisa, refere-se ao fato da excelente correlação entre ela e outras metodologias clássicas, fato comprovado quando isolados de leveduras pertencentes à coleção de culturas do Departamento de Ciência e Tecnologia Agroindustrial da ESALQ/USP, foram identificados pela metodologia em questão e, posteriormente, enviados à outras instituições de pesquisa para confronto de resultados, chegando-se a mesma identificação.

\subsubsection{Preparo do material utilizado na identificação de leveduras}

Os testes de assimilação e fermentação de fontes de carbono, redução de nitrato à nitrito, crescimento das culturas à temperatura de $37^{\circ} \mathrm{C}$ e tolerância osmótica das células, foram realizados em tubos de ensaio de $10 \mathrm{~mm} \times 75 \mathrm{~mm}$, enquanto o teste para verificação da hidrólise de amido foi realizado em placas de Petri de $100 \mathrm{~mm} \times 20 \mathrm{~mm}$.

Alíquotas de 2,5 mL de meio basal contendo a fonte de carbono a ser testada, na proporção de $2 \%$ em relação ao volume de meio (exceto para a rafinose, cuja proporção utilizada foi de $4 \%$ ), foram distribuídas nos tubos de ensaio. Para os testes de fermentação, tubos de Durham (4 mm x $30 \mathrm{~mm}$ ) invertidos foram acrescentados nos tubos de ensaio correspondentes. Também, 
tubos testemunhas foram preparados contendo apenas meio basal, na quantidade de $2,5 \mathrm{~mL}$ por tubo.

Ainda, alíquotas de $2,5 \mathrm{~mL}$ de meio de nitrato de potássio, $2,5 \mathrm{~mL}$ de caldo YEPD, 2,5 mL de caldo YEPD - 50\% glucose e 2,5 mL de caldo YEPD $10 \% \mathrm{NaCl}$, foram distribuídas em tubos de ensaio para realização dos testes de redução de nitrato à nitrito, crescimento das culturas à temperatura de $37^{\circ} \mathrm{C} \mathrm{e}$ tolerância osmótica das células, respectivamente.

Grades de alumínio com capacidade para 40 tubos, foram utilizadas para suporte dos tubos de ensaio (Figura 4) e cuidadosamente embrulhadas com folhas de alumínio, sendo esterilizadas conforme itens 4.3.1 e 4.3.2.

O meio de cultivo contendo amido, utilizado para se verificar a capacidade das culturas em hidrolisá-lo, foi devidamente preparado e esterilizado conforme item 4.3.1.

Placas de Petri contendo YEPD ágar esterilizado (item 4.3.1) acrescido dos inibidores bacterianos (100 ppm de cloranfenicol e $100 \mathrm{ppm}$ de tetraciclina), foram preparadas para servirem como placas mestras, a partir das quais, as culturas foram inoculadas nos tubos testes.

\subsubsection{Condução dos testes para identificação de leveduras}

Para agilizar o processo de identificação das leveduras isoladas, utilizou-se 1 replicador manual contendo 20 agulhas de inoculação (Figura 4), que permitia a identificação de 20 isolados a cada batelada de testes realizada. 
Assim, a partir dos tubos contendo YEPD ágar inclinado (item 4.8.2), 20 culturas eram selecionadas e inoculadas por placa mestra (Figura 5), sendo preparadas 5 placas idênticas, as quais foram incubadas a $28^{\circ} \mathrm{C} \pm 1^{\circ} \mathrm{C}$ durante 24 a 48 horas.

Após a incubação e com o auxilio do replicador manual, as culturas eram assepticamente transferidas das placas mestras para os tubos testes e para os tubos testemunhas, que foram incubados a $28^{\circ} \mathrm{C} \pm 1^{\circ} \mathrm{C}$ durante 48 a 72 horas, com exceção dos tubos para o teste de crescimento das culturas a $37^{\circ} \mathrm{C}$, os quais foram incubados a esta temperatura.

Com o auxilio de uma agulha de platina devidamente flambada e resfriada, as culturas selecionadas eram, ainda, inoculadas em placa de Petri contendo meio de amido, sendo preparadas em duplicata e incubadas a $28^{\circ} \mathrm{C} \pm 1^{\circ} \mathrm{C}$ durante 48 horas. 


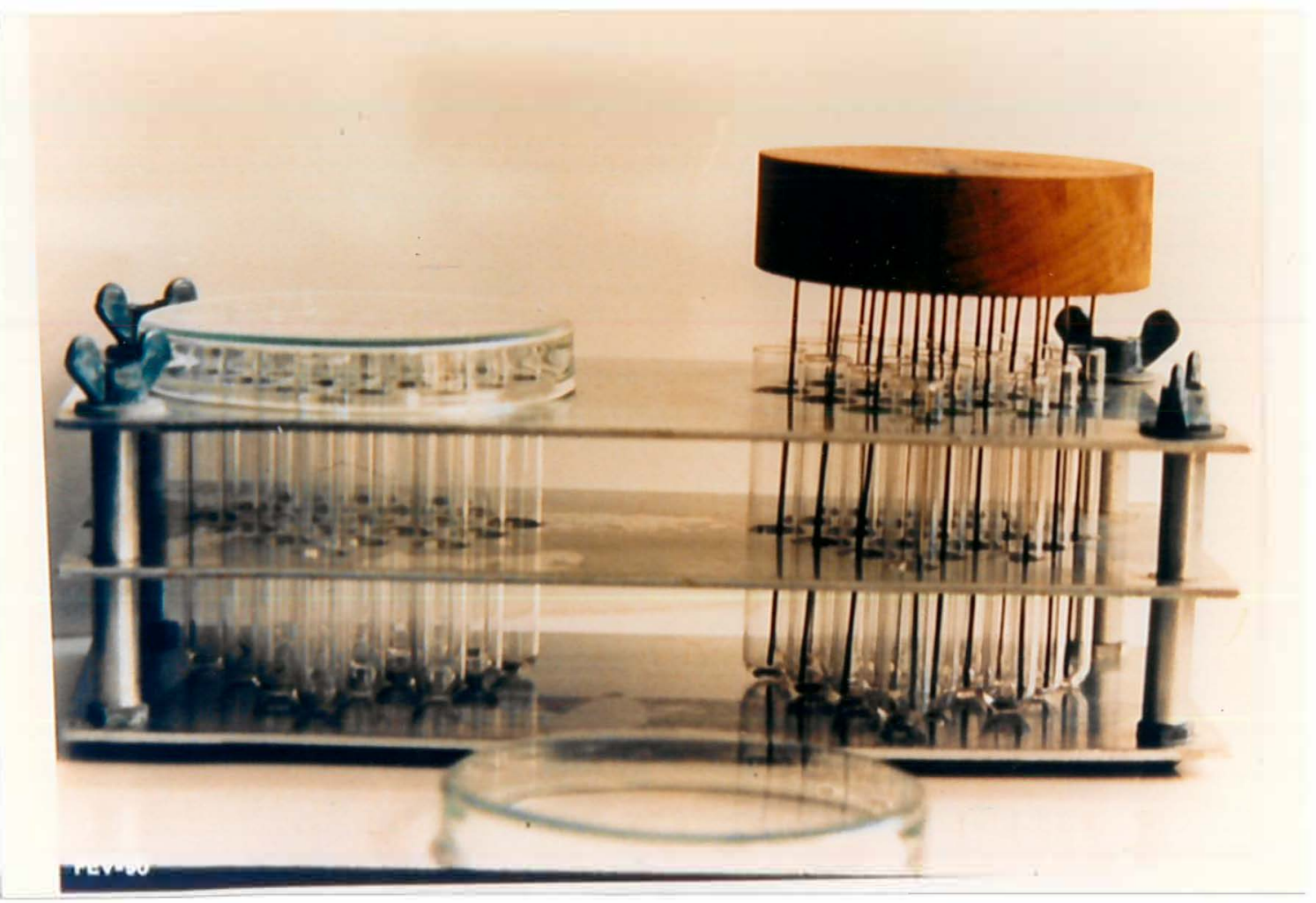

Figura 4 - Detalhe da grade de ahumínio e do replicador manual. 


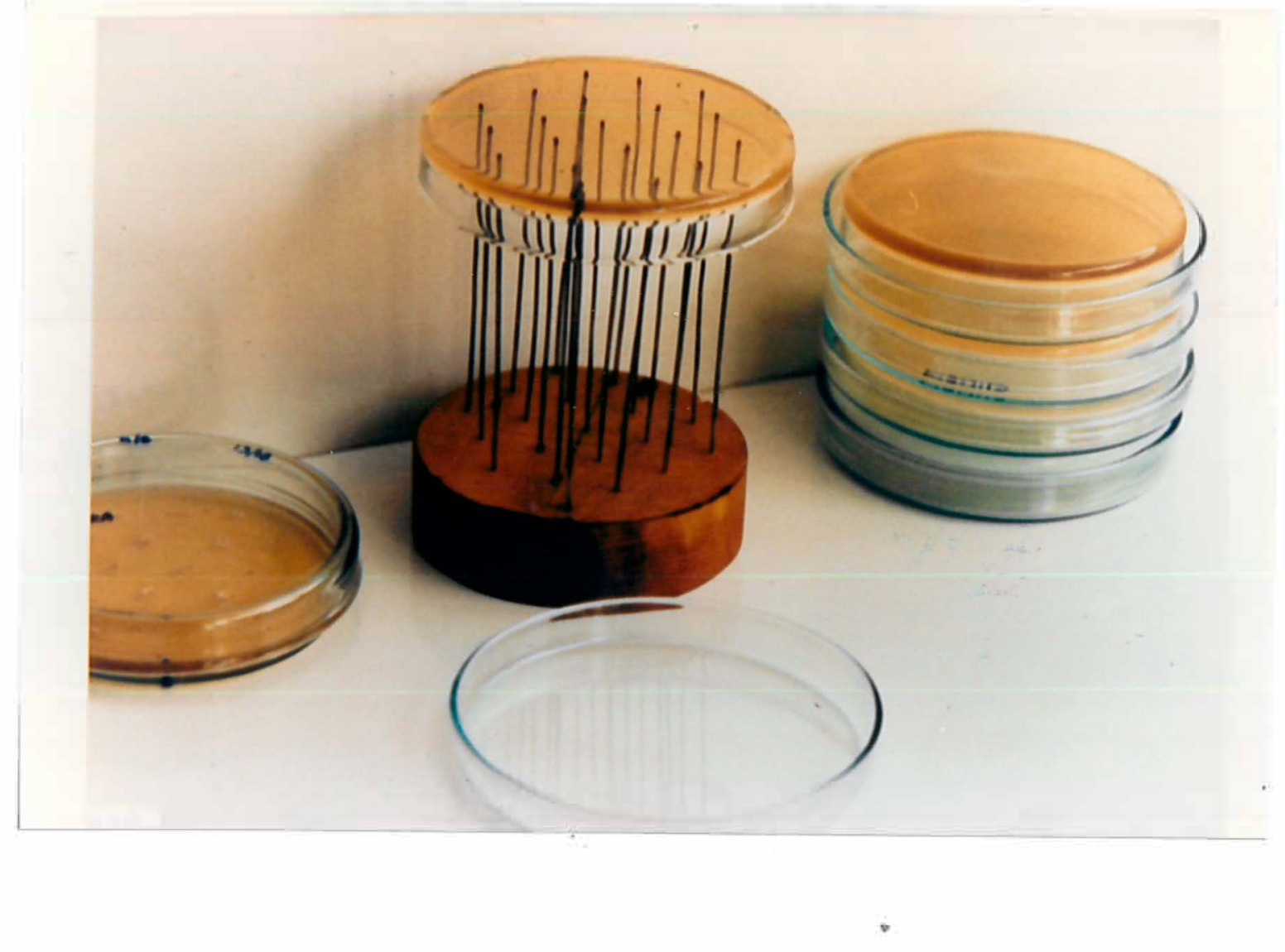

Figura 5 - Detalhe das placas mestras. 


\subsubsection{Leitura dos testes}

\subsection{Teste de assimilação e fermentação de fontes de carbono}

As leituras foram realizadas após 48 e 72 horas de incubação, sendo que a assimilação de cada uma das fontes testadas foi verificada comparando-se cada tubo teste com o respectivo tubo testemunha, o qual continha apenas o meio basal e a levedura a ser identificada. A assimilação foi considerada positiva quando havia crescimento da cultura no tubo teste (formação de massa celular e/ou turvação do meio) em relação ao tubo testemunha.

Já, para o teste de fermentação, analisou-se a presença ou ausência de bolhas de gás no interior dos tubos de Durham dos respectivos tubos testes, sendo a fermentação positiva, quando da presença de bolhas de gás em pelo menos $1 / 3$ do volume dos tubos de Durham.

\subsection{Teste de crescimento das culturas à temperatura de $37^{\circ} \mathrm{C}$}

Realizou-se a leitura após 48 horas de incubação e mediante resultados positivos, ou seja, crescimento das culturas (formação de massa celular e/ou turvação do meio) nos tubos testes, não se realizava nova leitura após 72 horas. Porém, frente à resultados negativos, os tubos retomavam à estufa e eram novamente analisados após as 72 horas de incubação. 


\subsection{Teste de tolerância osmótica das células}

Procedimento idêntico ao item 4.8.3.4.2, tanto para os tubos contendo caldo YEPD - 50\% glucose, como para os tubos com caldo YEPD - $10 \% \mathrm{NaCl}$.

\subsection{Teste de redução de nitrato à nitrito}

Leitura realizada após 48 horas de incubação, com a adição de duas gotas da solução A (item 4.2.4), seguida da adição de duas gotas da solução B (item 4.2.4), por tubo teste. O surgimento de coloração vermelha nos tubos após a adição das soluções $\mathrm{A}$ e $\mathrm{B}$, deveria ser interpretado como resultado positivo. Resultados negativos eram confirmados pela adição de pequena quantidade de zinco em pó ao tubo, agora com a coloração vermelha sendo devido à redução de nitrato pelo zinco adicionado. Caso não se observasse a coloração vermelha com a adição do zinco, o resultado era considerado positivo, uma vez que teria ocorrido a redução do nitrato à nitrito e a denitrificação total.

\subsection{Teste de hidrólise de amido}

Leitura realizada após 48 horas de incubação, com a adição da solução de lugol (item 4.2.5), cobrindo toda a superfície do meio de cultivo na placa contendo os isolados em teste. $\mathrm{O}$ surgimento de um halo claro ao redor das colônias era indicativo de resultado positivo. 


\subsection{Observação do tamanho celular}

A observação do tamanho celular das leveduras isoladas foi realizada durante o isolamento e purificação das culturas (item 4.8.2), utilizando-se um microscópio óptico comum, onde foram verificadas as dimensões das células. As células foram consideradas alongadas, quando o comprimento celular era, no mínimo, o dobro da largura, conforme especificação da metodologia adotada na presente pesquisa. 


\section{RESULTADOS E DISCUSSÃO}

Foram isoladas um total de 225 culturas de leveduras, das quais 195 puderam ser identificadas através da metodologia utilizada.

$\mathrm{O}$ número total de culturas isoladas e de culturas identificadas nas Usinas da Pedra, Santa Elisa e na Destilaria Mandú, bem como o número de culturas identificadas em cada ponto amostrado nestas unidades industriais, encontram-se demonstrados na Tabela 1.

A Tabela 2 contém as abreviações utilizadas para designar as espécies de leveduras citadas nas Figuras de 6 a 17.

As Figuras 6, 7 e 8 demonstram as leveduras identificadas nas Usinas da Pedra, Santa Elisa e na Destilaria Mandú e suas respectivas porcentagens.

Nas Tabelas 3, 4 e 5 as leveduras identificadas estão relacionadas separadamente por ponto amostrado e unidade industrial. As leveduras indicadas entre parênteses correspondem à atualização das espécies, segundo Bamett et al. (1983); Bamett et al. (1990) e Kreger-van Rij (1984).

As porcentagens de cada isolado identificado em cada ponto amostrado das respectivas unidades industriais estão representadas pelas Figuras de 9 a 17. 
Tabela 1 - Número total de culturas isoladas e de culturas identificadas e número de culturas identificadas em cada ponto amostrado nas Usinas da Pedra, Santa Elisa e na Destilaria Mandú.

\begin{tabular}{l|c|cccc}
\hline & & \multicolumn{4}{|c}{ CULTURAS IDENTIFICADAS } \\
$\begin{array}{lcccc}\text { UNIDADES } \\
\text { INDUSTRIAIS }\end{array}$ & $\begin{array}{l}\text { CULTURAS } \\
\text { ISOLADAS }\end{array}$ & $\begin{array}{c}\text { TOTAL } \\
\text { CALDO }\end{array}$ & PRIMÁRIO & MOSTO & LEITE DE \\
\hline PEDRA & 78 & 72 & 30 & 14 & 28 \\
SANTA ELISA & 63 & 55 & 16 & 15 & 24 \\
& 84 & 68 & 25 & 26 & 17 \\
\hline
\end{tabular}


Tabela 2 - Abreviaçỏes utilizadas para designar as espécies de leveduras citadas nas Figuras de 6 a 17.

\begin{tabular}{|c|c|}
\hline ABREVIACCÕES & LEVEDURAS \\
\hline Sce:Suv & - Saccharomyces cerevisiae: S. uvarum \\
\hline Sco & - Saccharomyces coreanus \\
\hline Sch & - Saccharomyces chevalieri \\
\hline Spr & - Saccharomyces pretoriensis \\
\hline Sba & - Saccharomyces bayomus \\
\hline Sca & - Saccharomyces capensis \\
\hline Sgl & - Saccharomyces globosus \\
\hline Sbe & - Saccharomyces beticus \\
\hline Cme & - Candida membranaefaciens \\
\hline Cru & - Condida rugosa \\
\hline Ckr:Tca & - Candida krusei: Torulopsis castellii \\
\hline Cen & - Condida entomophila \\
\hline Cpa & - Candida parapsilosis \\
\hline Crh & - Condida rhagii \\
\hline Tha & - Torulopsis haemulonii \\
\hline Tda & - Torulopsis dattila \\
\hline $\operatorname{Tin}$ & - Torulopsis inconspicua \\
\hline Pgu & - Pichia guilliermondii \\
\hline Pme & - Pichia membranaefaciens \\
\hline Poh & - Pichia ohmeri \\
\hline Psp & - Pichia spartinae \\
\hline Pet & - Pichia etchellsii \\
\hline Pte & - Pichia terricola \\
\hline Szp & - Schizosaccharomyces pombe \\
\hline Trb & - Trichosporon brassicae \\
\hline $\mathrm{Rgl}$ & - Rhodotorula glutinis \\
\hline
\end{tabular}




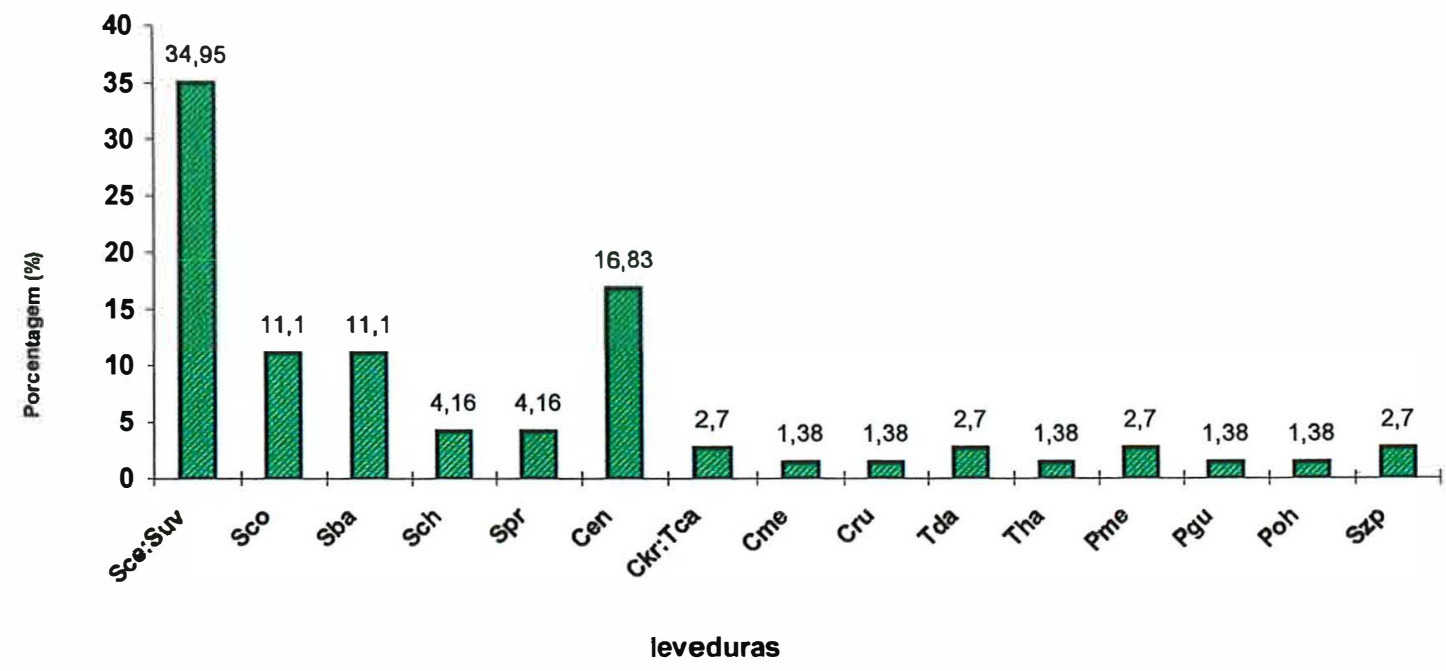

Figura 6 - Leveduras identificadas na Usina da Pedra.

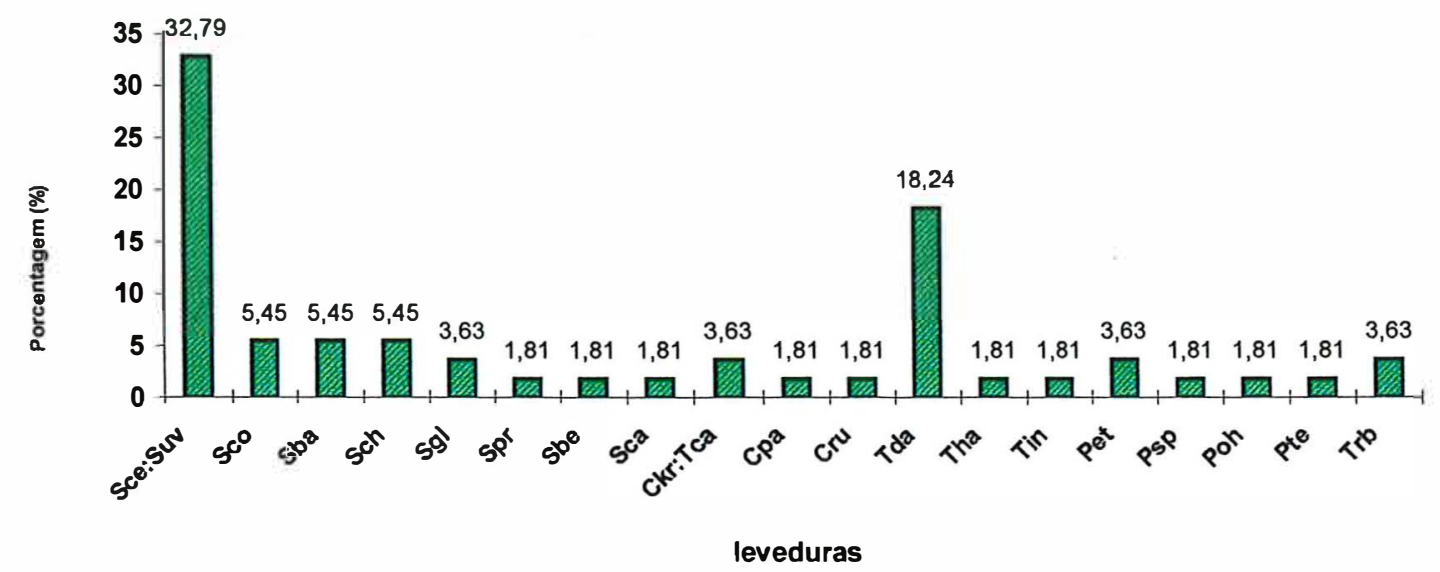

Figura 7 - Leveduras identificadas na Usina Santa Elisa.

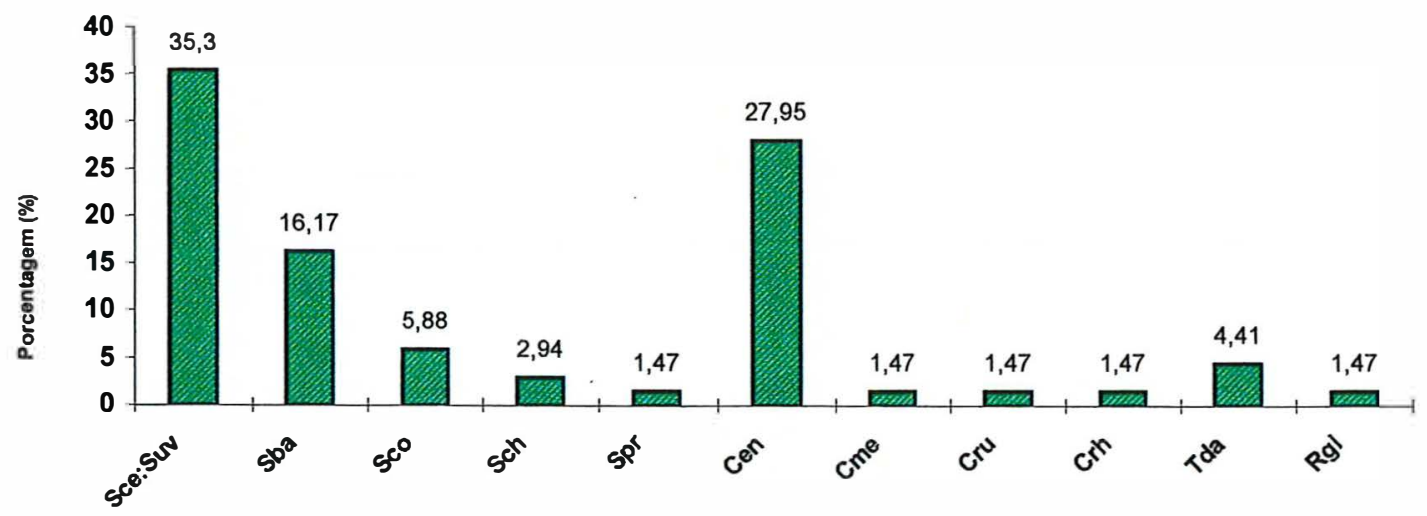

leveduras

Figura 8 - Leveduras identificadas na Destilaria Mandú. 
Tabela 3 - Leveduras identificadas nas amostras de caldo primário, mosto e leite de leveduras na Usina da Pedra.

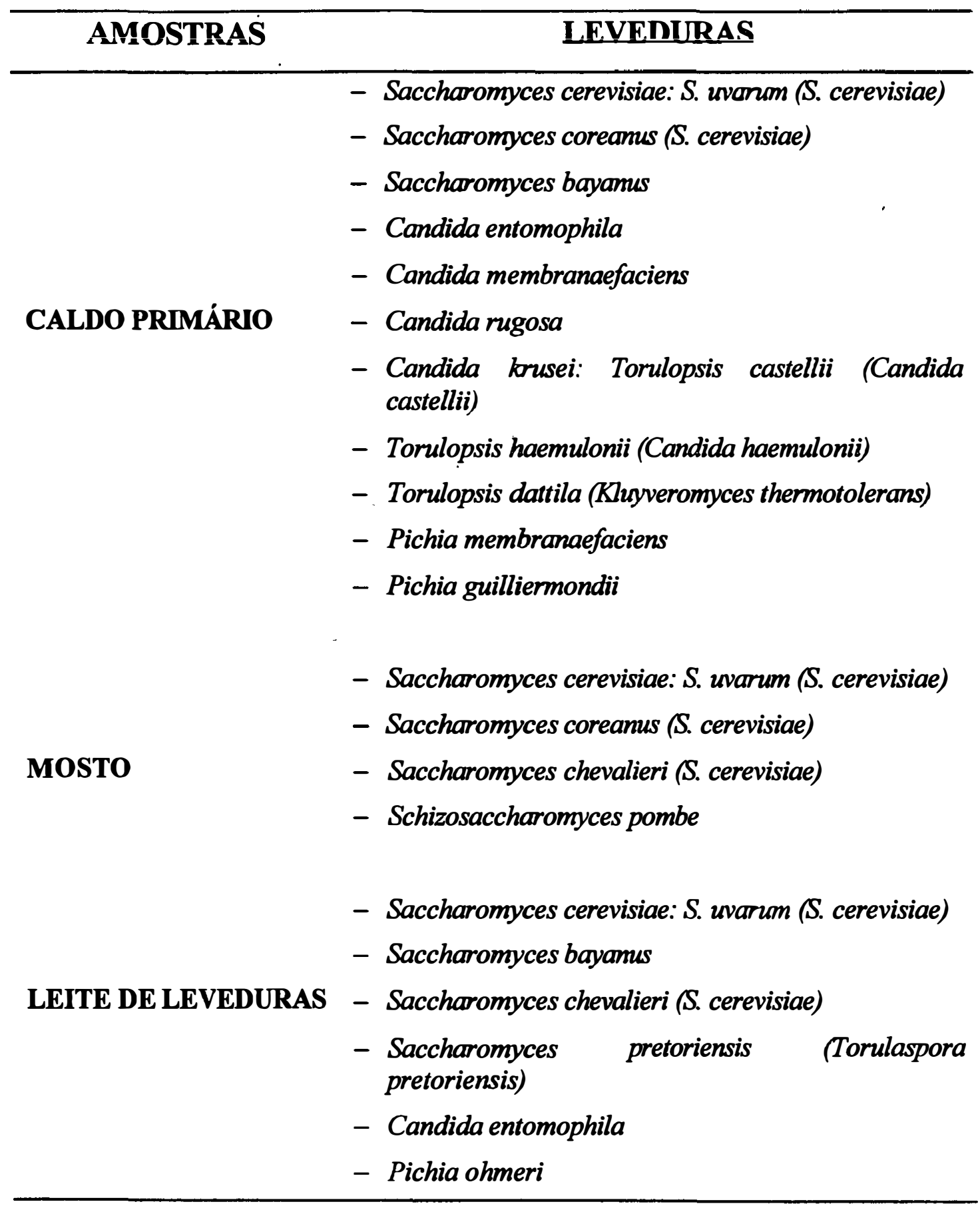


Tabela 4 - Leveduras identificadas nas amostras de caldo primário, mosto e leite de leveduras na Usina Santa Elisa.

\begin{tabular}{|c|c|}
\hline AMNSTRAS & L,F.VF,DIRAS \\
\hline CALDO PRIMÁRIO & $\begin{array}{l}\text { - Saccharomyces cerevisiae: S. uvarum (S. cerevisiae) } \\
\text { - Saccharomyces globosus (S. cerevisiae) } \\
\text { - Saccharomyces capensis (S. cerevisiae) } \\
\text { - Candida parapsilosis } \\
\text { - Candida brusei: Torulopsis castellii (Candida } \\
\text { castellii) } \\
\text { - Torulopsis dattila (Kluyveromyces thermotolerans) } \\
\text { - Torulopsis inconspicua (Candida inconspicua) } \\
\text { - Pichia spartinae } \\
\text { - Pichia ohmeri }\end{array}$ \\
\hline MOSTO & $\begin{array}{l}\text { - Saccharomyces cerevisiae: S. uvarum (S. cerevisiae) } \\
\text { - Saccharomyces coreamus (S. cerevisiae) } \\
\text { - Saccharomyces chevalieri (S. cerevisiae) } \\
\text { - Saccharomyces bayamus } \\
\text { - Torulopsis dattila (Kluyveromyces thermotolerans) } \\
\text { - Torulopsis haemulonii (Candida haemulonii) } \\
\text { - Pichia etchellsii } \\
\text { - Trichosporon brassicae }\end{array}$ \\
\hline \multirow{3}{*}{ LEITE DE LEVEDURAS } & $\begin{array}{l}\text { - Saccharomyces cerevisiae: S. uvarum (S. cerevisiae) } \\
\text { - Saccharomyces coreamus (S. cerevisiae) } \\
\text { - Saccharomyces globosus (S. cerevisiae) } \\
\text { - Saccharomyces chevalieri (S. cerevisiae) } \\
\text { - Saccharomyces bayamus }\end{array}$ \\
\hline & $\begin{array}{lll}\text { - Saccharomyces pretoriensis } & \text { (Torulaspora } \\
\text { pretoriensis) } & & \\
\text { - Candida rugosa } & & \end{array}$ \\
\hline & $\begin{array}{l}\text { - Candida krusei: Torulopsis castellii (Candida } \\
\text { castellii) } \\
\text { - Torulopsis dattila (Kluyveromyces thermotolerans) } \\
\text { - Pichia terricola (Issatchenkia terricola) } \\
\text { - Trichosporon brassicae }\end{array}$ \\
\hline
\end{tabular}


Tabela 5 - Leveduras identificadas nas amostras de caldo primário, mosto e leite de leveduras na Destilaria Mandú.

\section{AMOSTRAS LEVEDURAS}

- Saccharomyces cerevisiae: S. uvarum (S. cerevisiae)

- Saccharomyces coreamus (S. cerevisiae)

- Saccharomyces bayamus

CALDO PRIMÁRIO - Candida entomophila

- Candida rugosa

- Torulopsis dattila (Klugveromyces thermotolerans)

- Saccharomyces cerevisiae: S. uvarum (S. cerevisiae)

- Saccharomyces boyomus

- Saccharomyces chevalieri (S. cerevisiae)

MOSTO

- Candida entomophila

- Candida membranaefaciens

- Torulopsis dattila (Kluyveromyces thermotolerans)

- Rhodotorula glutinis

- Saccharomyces cerevisiae: S. uvarum (S. cerevisiae)

- Saccharomyces coreamus (S. cerevisiae)

LEITE DE LEVEDURAS - Saccharomyces bayamus

- Saccharomyces pretoriensis (Torulaspora pretoriensis)

- Candida entomophila

- Candida rhagii 


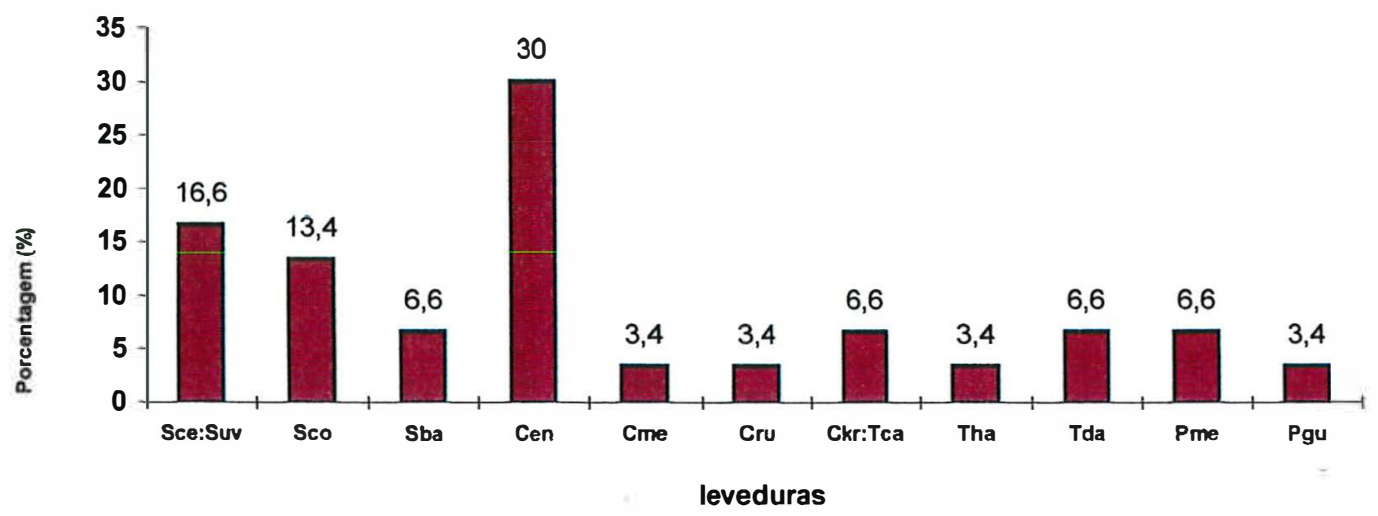

Figura 9 - Porcentagens dos isolados identificados no caldo primário na Usina da Pedra.

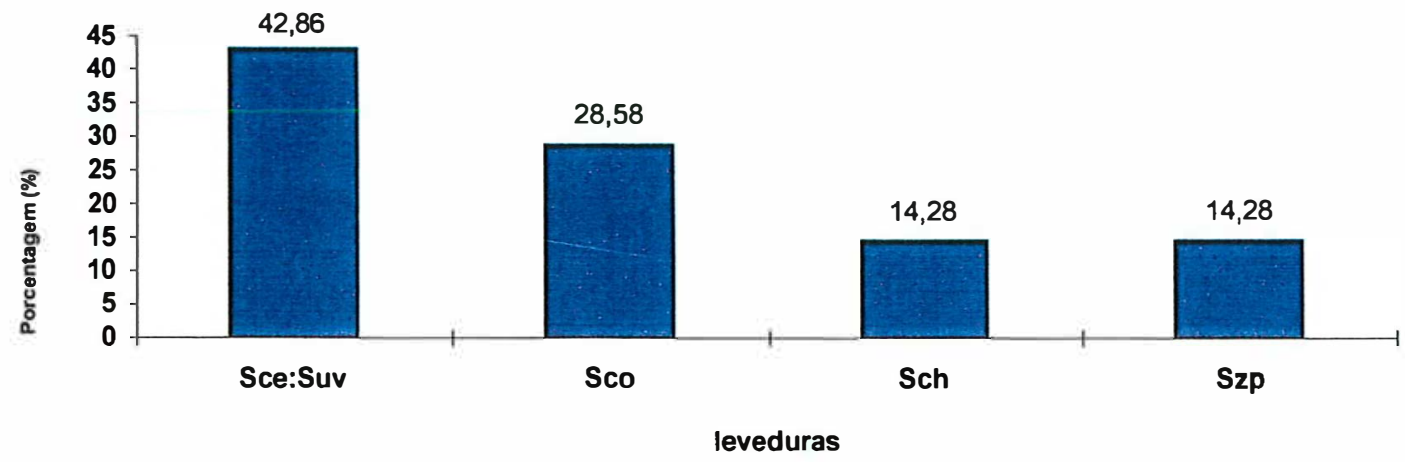

Figura 10 - Porcentagens dos isolados identificados no mosto na Usina da Pedra.

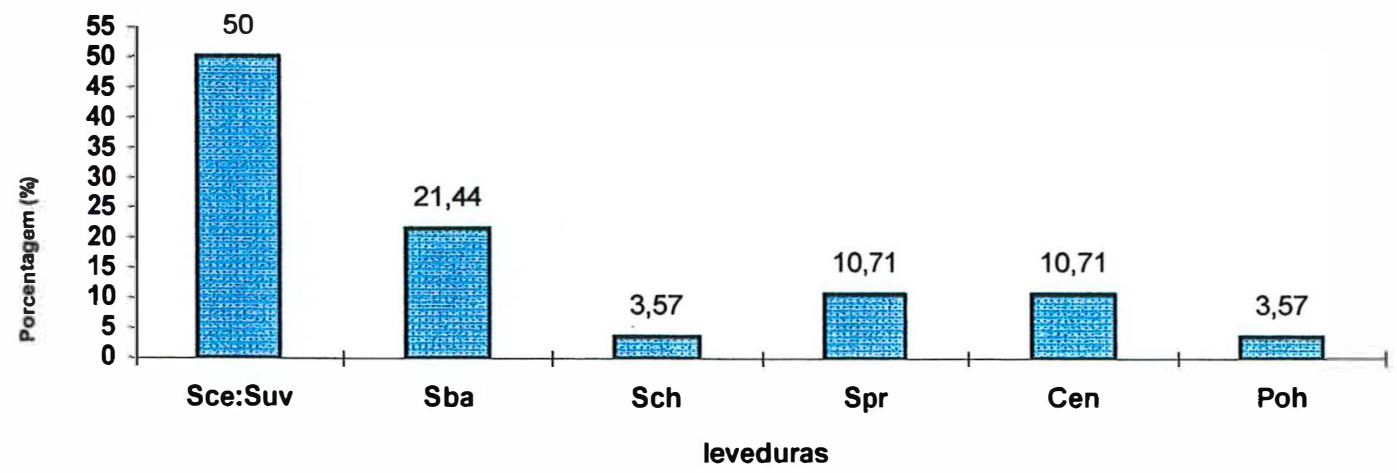

Figura 11 - Porcentagens dos isolados identificados no leite de leveduras na Usina da Pedra. 


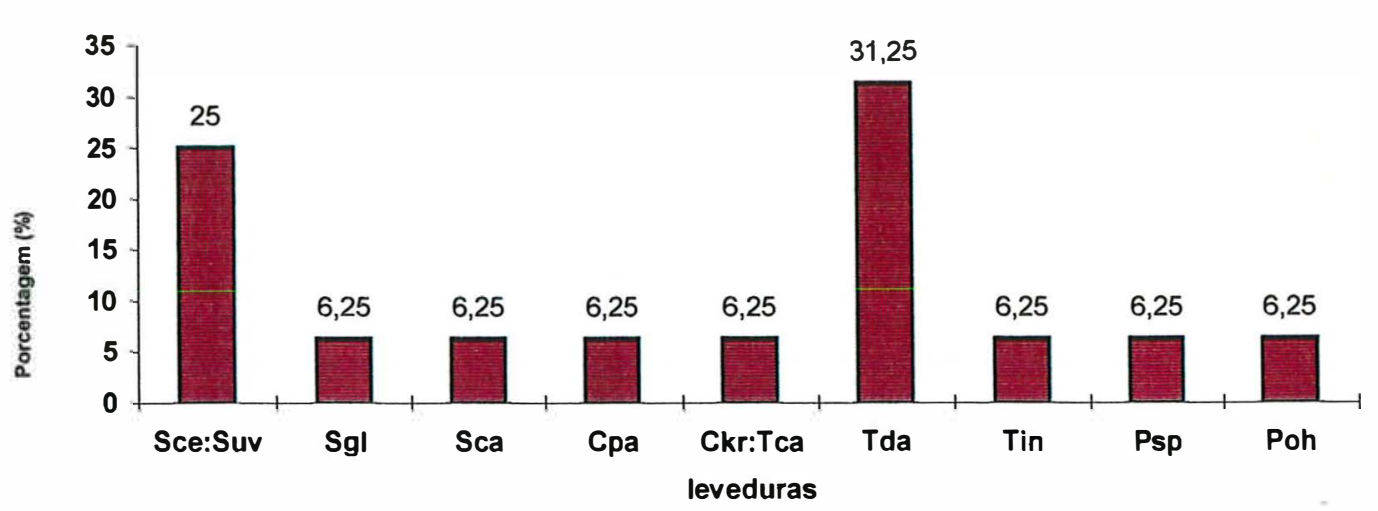

Figura 12 - Porcentagens dos isolados identificados no caldo primário na Usina Santa Elisa.

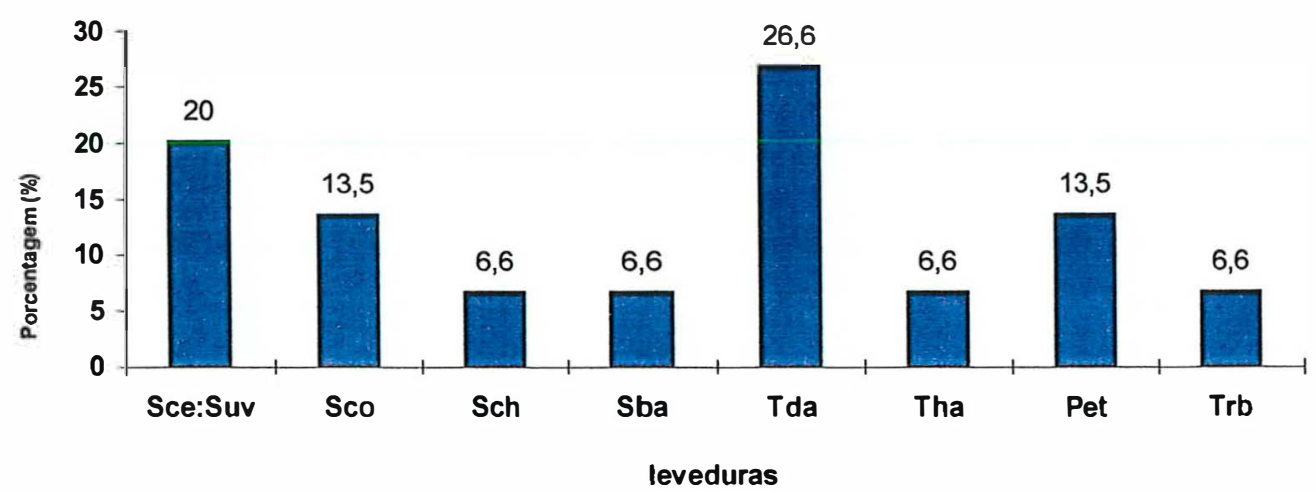

Figura 13 - Porcentagens dos isolados identificados no mosto na Usina Santa Elisa.

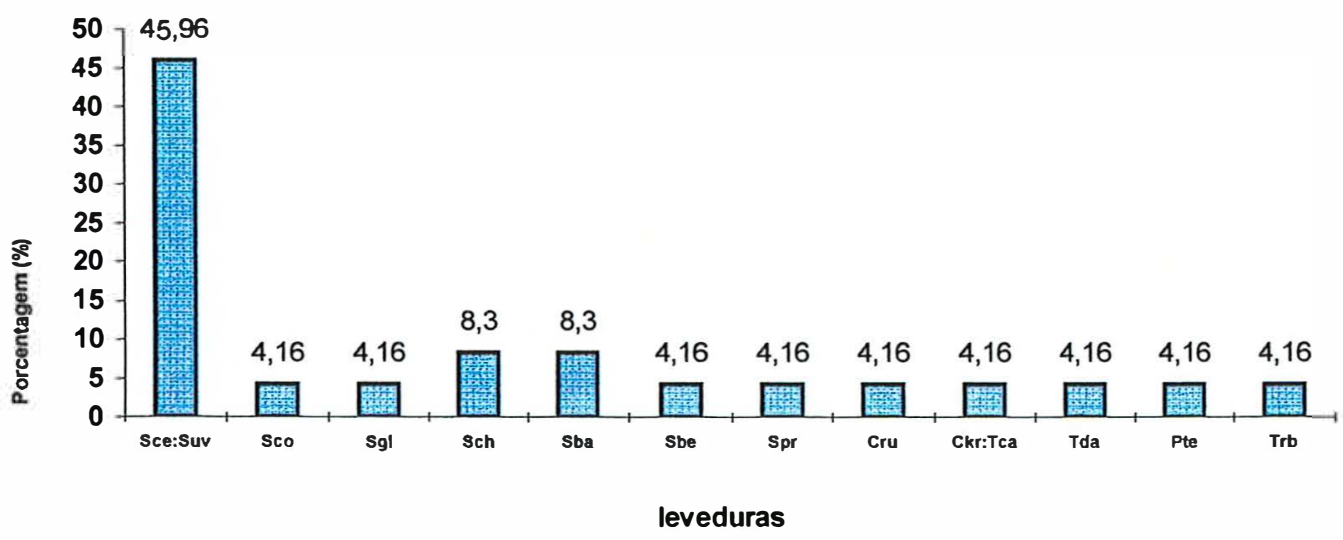

Figura 14 - Porcentagens dos isolados identificados no leite de leveduras na Usina Santa Elisa. 


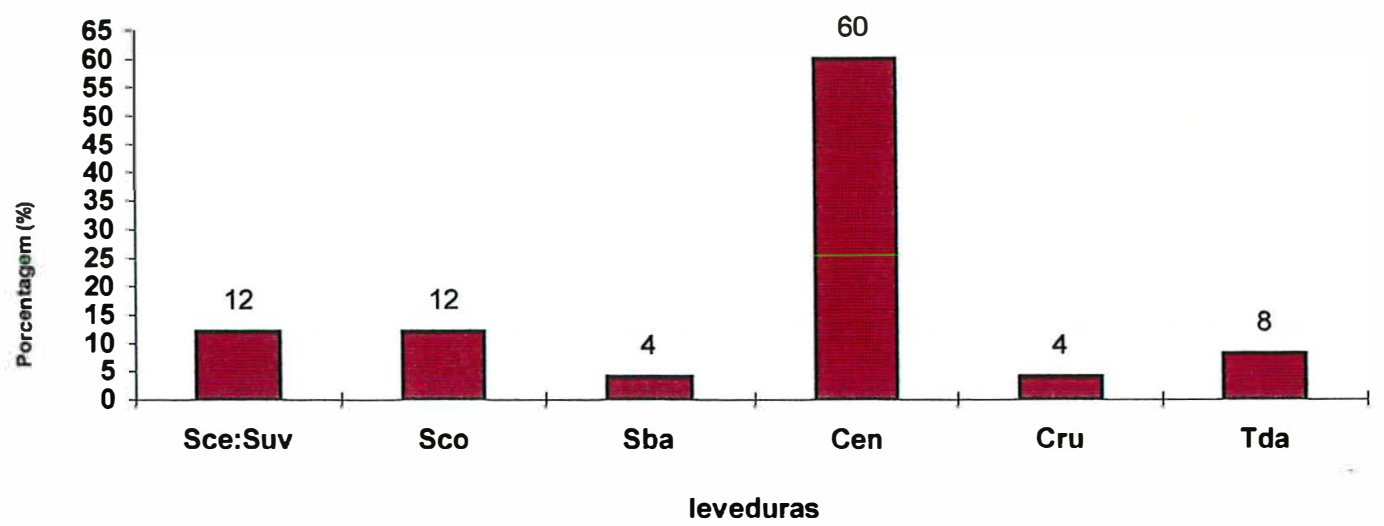

Figura 15 - Porcentagens dos isolados identificados no caldo primário na Destilaria Mandú.

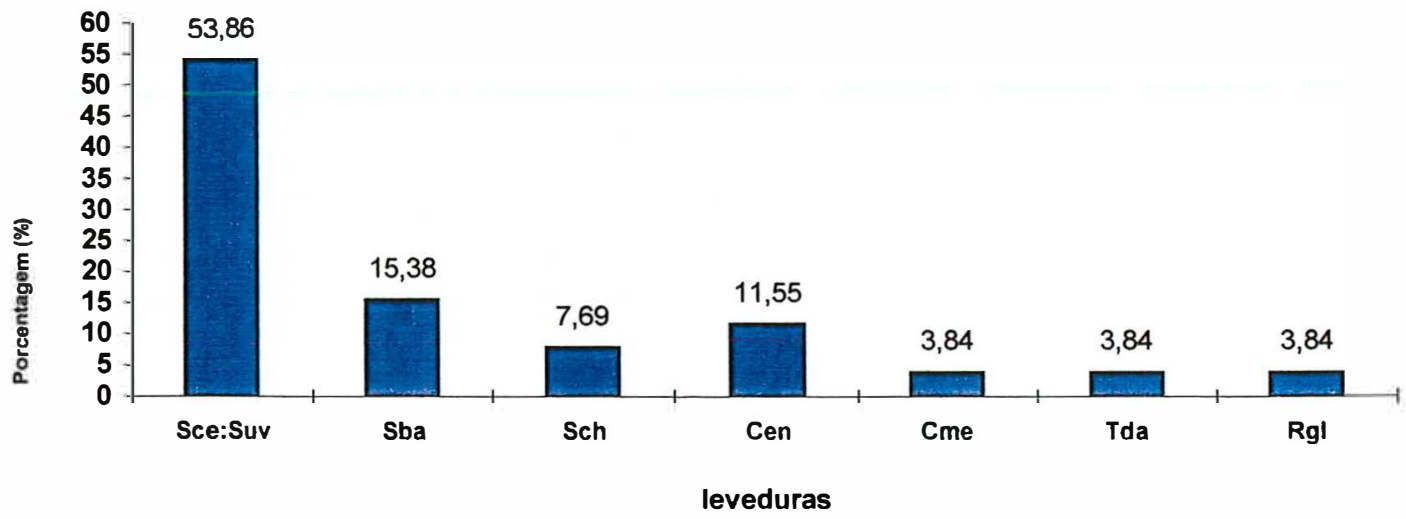

Figura 16 - Porcentagens dos isolados identificados no mosto na Destilaria Mandú.

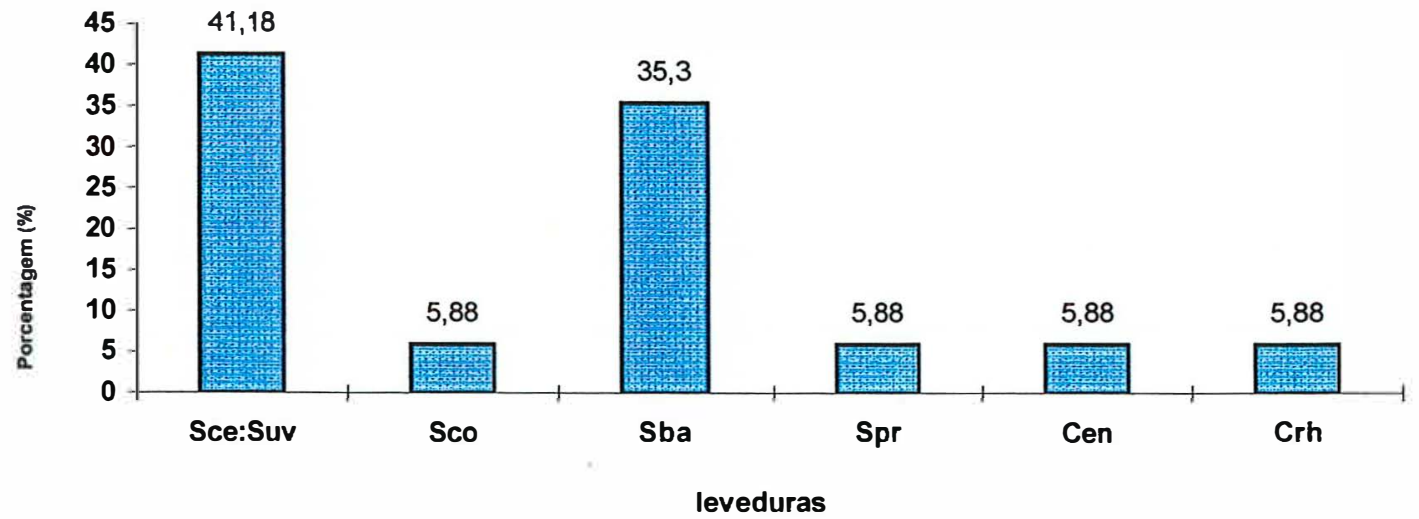

Figura 17 - Porcentagens dos isolados identificados no leite de leveduras na Destilaria Mandú. 
As Tabelas de 6 a 14 demonstram as leveduras presentes nas amostragens mensais de caldo primário, mosto e leite de leveduras, em cada unidade industrial.

Tabela 6 - Leveduras presentes nas amostragens mensais de caldo primário na Usina da Pedra.

\begin{tabular}{ll}
\hline \multicolumn{1}{c}{ MESES } & \multicolumn{1}{c}{ LEVEDURAS } \\
\hline MAIO & - Candida entomophila \\
& - Candida membranaefaciens \\
& - Candida rugosa \\
& - Pichia guilliermondii \\
& - Torulopsis haemulonii (Candida haemulonii) \\
JUNHO & - Candida entomophila \\
& - Pichia membranaefaciens \\
& - Saccharomyces cerevisiae: S. uvarum (S. cerevisiae) \\
& - Saccharomyces bayanus \\
& - Saccharomyces coreanus (S. cerevisiae) \\
& - Torulopsis dattila (Kluyveromyces thermotolerans) \\
& - Candida entomophila \\
& - Candida krusei: Torulopsis castellii (Candida castellii) \\
& - Saccharomyces cerevisiae: S. uvarum (S. cerevisiae) \\
& - Saccharomyces bayanus \\
& - Saccharomyces coreanus (S. cerevisiae) \\
& - Torulopsis dattila (Kluyveromyces thermotolerans) \\
AGOSTO & - Candida entomophila \\
& - Candida krusei: Torulopsis castellii (Candida castellii) \\
& - Pichia membranaefaciens \\
& - Candida entomophila \\
& - Saccharomyces cerevisiae: S. uvarum (S. cerevisiae) \\
& - Saccharomyces coreanus (S. cerevisiae) \\
& - Candida entomophila \\
&
\end{tabular}


Tabela 7 - Leveduras presentes nas amostragens mensais de mosto na Usina da Pedra.

MAIO

MESES LEVEDURAS

JUNHO

- Saccharomyces cerevisiae: S. uvarum (S. cerevisiae)

- Saccharomyces coreanus (S. cerevisiae)

- Saccharomyces cerevisiae: S. uvarum (S. cerevisiae)

- Saccharomyces chevalieri (S. cerevisiae)

- Saccharomyces cerevisiae: S. uvarum (S. cerevisiae)

JULHO - Saccharomyces chevalieri (S. cerevisiae)

- Saccharomyces coreanus (S. cerevisiae)

SETEMBRO - Schizosaccharomyces pombe

OUTUBRO - Schizosaccharomyces pombe 
Tabela 8 - Leveduras presentes nas amostragens mensais de leite de leveduras na Usina da Pedra.

\begin{tabular}{ll}
\hline \multicolumn{1}{c}{ MESES } & \multicolumn{1}{c}{ LEVEDURAS } \\
\hline MAIO & - Saccharomyces cerevisiae: S. uvarum (S. cerevisiae) \\
& - Saccharomyces bayanus \\
& - Candida entomophila \\
& - Pichia ohmeri \\
JUNHO & - Saccharomyces bayanus \\
& - Candida entomophila \\
JULHO & - Saccharomyces cerevisiae: S. uvarum (S. cerevisiae) \\
& - Saccharomyces cerevisiae: S. uvarum (S. cerevisiae) \\
AGOSTO & - Saccharomyces pretoriensis (Torulaspora pretoriensis) \\
&
\end{tabular}


Tabela 9 - Leveduras presentes nas amostragens mensais de caldo primário na Usina Santa Elisa.

\section{MESES}

\section{LEVEDURAS}

MAIO

- Torulopsis dattila (Kluyveromyces thermotolerans)

- Torulopsis dattila (Kluyveromyces thermotolerans)

JUNHO

- Torulopsis inconspicua (Candida inconspicua)

- Saccharomyces globosus (S. cerevisiae)

- Candida parapsilosis

AGOSTO

- Candida krusei: Torulopsis castellii (Candida castellii)

- Pichia spartinae

SETEMBRO

- Saccharomyces cerevisiae: S. uvarum (S. cerevisiae)

- Saccharomyces capensis (S. cerevisiae)

- Torulopsis dattila (Kluyveromyces thermotolerans)

OUTUBRO - Saccharomyces cerevisiae: S. uvarum (S. cerevisiae)

- Pichia ohmeri 
Tabela 10 - Leveduras presentes nas amostragens mensais de mosto na Usina Santa Elisa.

JUNHO

- Torulopsis dattila (Klugveromyces thermotolerans)

- Saccharomyces bayanus

- Pichia etchellsii

- Trichosporon brassicae

JULHO

- Torulopsis dattila (Kluyveromyces thermotolerans)

- Saccharomyces chevalieri (S. cerevisiae)

AGOSTO

- Torulopsis dattila (Kluyveromyces thermotolerans)

- Torulopsis haemulonii (Candida haemulonii)

- Saccharomyces cerevisiae: S. uvarum (S. cerevisiae)

SETEMBRO

- Saccharomyces coreanus (S. cerevisiae)

OUTUBRO - Saccharomyces cerevisiae: S. uvarum (S. cerevisiae) 
Tabela 11 - Leveduras presentes nas amostragens mensais de leite de leveduras na Usina Santa Elisa.

\begin{tabular}{ll}
\hline \multicolumn{1}{c}{ MESES } & \multicolumn{1}{c}{ LEVEDURAS } \\
\hline MAIO & - Saccharomyces bayanus \\
& - Saccharomyces beticus (S. cerevisiae) \\
JUNHO & - Saccharomyces cerevisiae: S. uvarum (S. cerevisiae) \\
& - Torulopsis dattila (Kluyveromyces thermotolerans) \\
& - Candida krusei: Torulopsis castellii (Candida castellii) \\
JULHO & - Saccharomyces cerevisiae: S. uvarum (S. cerevisiae) \\
& - Pichia terricola (Issatchenkia terricola) \\
& - Trichosporon brassicae \\
& - Saccharomyces cerevisiae: S. uvarum (S. cerevisiae) \\
& - Saccharomyces chevalieri (S. cerevisiae) \\
& - Saccharomyces pretoriensis (Torulaspora pretoriensis) \\
& \\
&
\end{tabular}


Tabela 12 - Leveduras presentes nas amostragens mensais de caldo primánio na Destilaria Mandú.

\begin{tabular}{|c|c|}
\hline MESES & LEVEDURAS \\
\hline MAIO & $\begin{array}{l}\text { - Candida entomophila } \\
\text { - Saccharomyces coreanus (S. cerevisiae) }\end{array}$ \\
\hline JUNHO & $\begin{array}{l}\text { - Candida entomophila } \\
\text { - Saccharomyces bayanus } \\
\text { - Saccharomyces coreanus (S. cerevisiae) }\end{array}$ \\
\hline JULHO & $\begin{array}{l}\text { - Candida entomophila } \\
\text { - Saccharomyces cerevisiae: S. uvarum (S. cerevisiae) } \\
\text { - Torülopsis dattila (Kluyveromyces thermotolerans) }\end{array}$ \\
\hline AGOSTO & $\begin{array}{l}\text { - Candida entomophila } \\
\text { - Saccharomyces coreanus (S. cerevisiae) }\end{array}$ \\
\hline SETEMBRO & $\begin{array}{l}\text { - Candida entomophila } \\
\text { - Candida rugosa } \\
\text { - Saccharomyces cerevisiae: S. uvarum (S. cerevisiae) }\end{array}$ \\
\hline OUTUBRO & $\begin{array}{l}\text { - Saccharomyces cerevisiae: S. uvarum (S. cerevisiae) } \\
\text { - Torulopsis dattila (Kluyveromyces thermotolerans) }\end{array}$ \\
\hline
\end{tabular}


Tabela 13 - Leveduras presentes nas amostragens mensais de mosto na Destilaria Mandú.

\begin{tabular}{|c|c|}
\hline MESES & LEVEDURAS \\
\hline MAIO & $\begin{array}{l}\text { - Saccharomyces cerevisiae: S. uvarum (S. cerevisiae) } \\
\text { - Saccharomyces chevalieri (S. cerevisiae) } \\
\text { - Candida entomophila } \\
\text { - Candida membranaefaciens }\end{array}$ \\
\hline JUNHO & $\begin{array}{l}\text { - Saccharomyces cerevisiae: S. uvarum (S. cerevisiae) } \\
\text { - Saccharomyces bayanus } \\
\text { - Torulopsis dattila (Kluyveromyces thermotolerans) }\end{array}$ \\
\hline JULHO & - Saccharomyces cerevisiae: S. uvarum (S. cerevisiae) \\
\hline AGOSTO & $\begin{array}{l}\text { - Saccharomyces cerevisiae: S. uvarum (S. cerevisiae) } \\
\text { - Saccharomyces chevalieri (S. cerevisiae) } \\
\text { - Candida entomophila }\end{array}$ \\
\hline SETEMBRO & $\begin{array}{l}\text { - Saccharomyces cerevisiae: S. uvarum (S. cerevisiae) } \\
\text { - Rhodotorula glutinis }\end{array}$ \\
\hline OUTUBRO & - Saccharomyces cerevisiae: S. uvarum (S. cerevisiae) \\
\hline
\end{tabular}


Tabela 14 - Leveduras presentes nas amostragens mensais de leite de leveduras na Destilaria Mandú.

\section{MESES LEVEDURAS}

MAIO

- Saccharomyces bayanus

JUNHO

- Saccharomyces bayanus

JULHO

- Saccharomyces cerevisiae: S. uvarum (S. cerevisiae)

- Saccharomyces bayanus

AGOSTO - Saccharomyces coreanus (S. cerevisiae)

- Candida entomophila

- Saccharomyces cerevisiae: S. uvarum (S. cerevisiae)

SETEMBRO

- Saccharomyces pretoriensis (Torulaspora pretoriensis)

OUTUBRO

- Saccharomyces cerevisiae: S. uvarum (S. cerevisiae)

- Candida rhagii 
Os gêneros de leveduras presentes nas 3 unidades industriais e suas respectivas porcentagens, encontram-se representados pela Figura 18.

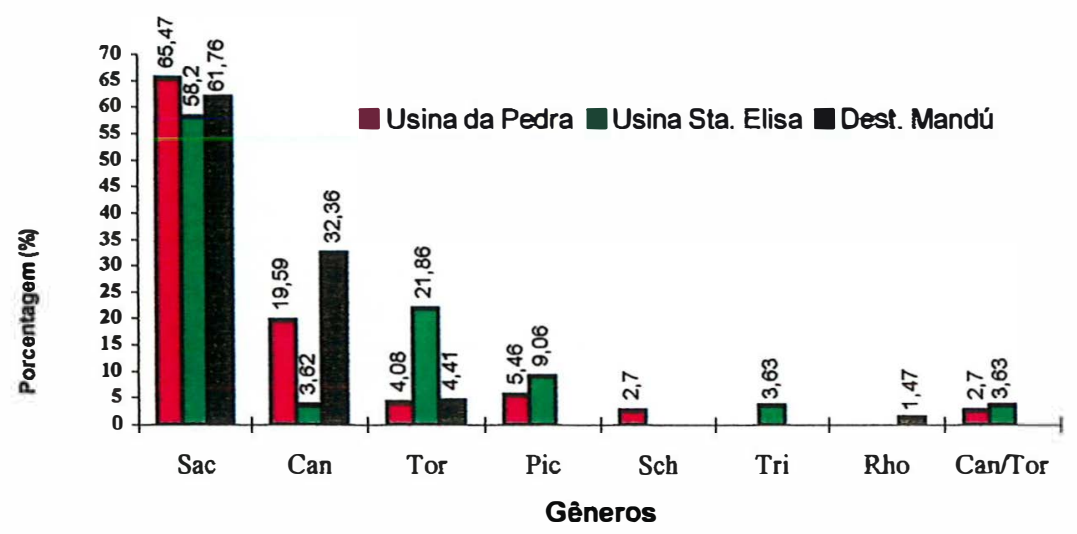

Figura 18 - Gêneros de leveduras encontrados nas Usinas da Pedra, Santa Elisa e Destilaria Mandú.

(Sac=Saccharomyces, $\quad$ Can=Candida,$\quad$ Tor=Torulopsis,
$\begin{aligned} & \text { Sch=Schizosaccharomyces, } \\ & \text { Can/Tor=Candida/Torulopsis }) .\end{aligned}$ 
Como pode ser observado pela análise das Figuras 6, 7 e 8, que demonstram respectivamente, as leveduras identificadas nas Usinas da Pedra, Santa Elisa e na Destilaria Mandú, 26 espécies de leveduras, pertencentes a 7 gêneros foram detectadas, sendo elas: Saccharomyces cerevisiae: S. uvarum (S. cerevisiae), S. coreanus (S. cerevisiae), S. bayanus, S. chevalieri (S. cerevisiae), S. globosus (S. cerevisiae), S. beticus (S. cerevisiae), S. capensis (S. cerevisiae), S. pretoriensis (Torulaspora pretoriensis), Candida entomophila, C. membranaefaciens, C. rugosa, C. parapsilosis, C. rhagii, C. krusei: Torulopsis castellii (Candida castellii), Torulopsis dattila (Kluyveromyces thermotolerans), T. haemulonii (Candida haemulonii), T. inconspicua (Candida inconspicua), Pichia membranaefaciens, $P$. guilliermondii, $P$. ohmeri, $P$. etchellsii, $P$. spartinae, P. terricola (Issatchenkia terricola), Schizosaccharomyces pombe, Trichosporon brassicae e Rhodotorula glutinis.

Várias espécies de leveduras identificadas na presente pesquisa, condizem com identificações realizadas em unidades industriais produtoras de açúcar, álcool ou aguardente citadas na literatura (item 3.3).

As espécies Saccharomyces cerevisiae, S. chevalieri, Candida krusei e Pichia membranaefaciens, também foram identificadas por Neder (1957), de processos de fermentação para fabricação de aguardente.

As mesmas espécies citadas acima, além da espécie Schizosaccharomyces pombe, foram detectadas por Shehata (1960), também pesquisando leveduras presentes na fabricação de aguardente. 
A presente pesquisa demonstra a deteç̧ão da espécie Candida parapsilosis, sendo encontrada na literatura (Shehata, 1960), a espécie Candida parapsilosis var. intermedia, também identificada a partir de substratos do processo de fermentação alcoólica.

Candida krusei, identificada por Neder (1957) e Shehata (1960), também foi detectada por Amorim et al. (1989), Basso et al. (1994) e Basso et al. (1996), em processos de fermentação para produção de álcool.

Silva (1994), também identificou espécies como Saccharomyces cerevisiae, S. chevalieri, S. uvarum e Schizosaccharomyces pombe, em monitoramento microbiológico em unidade produtora de álcool.

Saccharomyces cerevisiae e S. chevalieri foram identificadas por Basso et al. (1993), que também detectaram as espécies $S$. coreanus e Pichia membranaefaciens de processos de fermentação alcoólica.

Em usina de açúcar de cana, a espécie Saccharomyces uvarum foi detectada por Lima et al. (1974).

Saccharomyces cerevisiae aparece também em trabalhos de Oliveira \& Pagnocca (1988) e Oliveira \& Silva (1993), como contaminante em processos de fermentação alcoólica.

As espécies Saccharomyces capensis, S. bayanus, Pichia ohmeri e Trichosporon brassicae, foram também citadas por Oliveira et al. (1996), como sendo identificadas durante processos de fermentação alcoólica.

Das leveduras identificadas na presente pesquisa, espécies como Rhodotorula glutinis, Saccharomyces cerevisiae, Pichia membranaefaciens e Candida krusei, são citadas como contaminantes em processos 
fermentativos para produção de vinhos, sendo as duas últimas espécies também encontradas em processos de fabricação de cerveja, conforme observa-se em breve revisão de literatura realizada sobre 0 assunto (item 3.3).

Particularmente, na Usina da Pedra, os 72 isolados identificados pertenceram a 15 espécies. A Figura 6 indica as espécies de leveduras identificadas nesta unidade industrial, sendo elas: Saccharomyces cerevisiae: S. uvarum (S. cerevisiae), S. coreanus (S. cerevisiae), S. bayanus, $S$. chevalieri (S. cerevisiae), S. pretoriensis (Torulaspora pretoriensis), Candida entomophila, C. krusei: Torulopsis castellii (Candida castellii), C. membranaefaciens, C. rugosa, Torulopsis dattila (Kluyveromyces thermotolerans), T. haemulonii (Candida haemulonii), Pichia membranaefaciens, P. guilliermondii, P. ohmeri e Schizosaccharomyces pombe.

Já, na Usina Santa Elisa, os 55 isolados identificados pertenceram a 19 espécies. A Figura 7 indica as espécies de leveduras identificadas nesta unidade industrial, sendo elas: Saccharomyces cerevisiae: $S$. uvarum ( $S$. cerevisiae), S. coreanus (S. cerevisiae), S. bayanus, S. chevalieri ( $S$. cerevisiae), S. globosus (S. cerevisiae), S. pretoriensis (Torulaspora pretoriensis), S. beticus (S. cerevisiae), S. capensis (S. cerevisiae), Candida krusei: Torulopsis castellii (Candida castellii), C. parapsilosis, C. rugosa, Torulopsis dattila (Kluyveromyces thermotolerans), T. haemulonii (Candida haemulonii), T. inconspicua (Candida inconspicua), Pichia etchellsii, P. 
spartinae, P. ohmeri, P. terricola (Issatchenkia terricola) e Trichosporon brassicae.

Os 68 isolados identificados na Destilaria Mandú, pertenceram a 11 espécies. A Figura 8 indica as espécies de leveduras identificadas nesta unidade industrial, sendo elas: Saccharomyces cerevisiae: $S$. uvarum ( $S$. cerevisiae), S. bayanus, S. coreanus (S. cerevisiae), S. chevalieri ( $S$. cerevisiae), S. pretoriensis (Torulaspora pretoriensis), Candida entomophila, C. membranaefaciens, C. rugosa, C. rhagii, Torulopsis dattila (Kluyveromyces thermotolerans) e Rhodotorula glutinis.

Assim, observa-se que a Usina da Pedra obteve o maior número de isolados identificados (72 isolados), seguida da Destilaria Mandú (68 isolados) e, finalmente, da Usina Santa Elisa (55 isolados). Contudo, a Usina Santa Elisa apresentou uma maior variedade de espécies identificadas (19 espécies), em relação à Usina da Pedra (15 espécies) e à Destilaria Mandú (11 espécies).

Analisando novamente as Figuras 6, 7 e 8, que demonstram respectivamente, as leveduras identificadas nas Usinas da Pedra, Santa Elisa e na Destilaria Mandú, observa-se que as espécies Saccharomyces cerevisiae: S. uvarum (S. cerevisiae), S. coreanus (S. cerevisiae), $S$. bayanus, S. chevalieri (S. cerevisiae), S. pretoriensis (Torulaspora pretoriensis), Candida rugosa e Torulopsis dattila (Kluyveromyces thermotolerans), foram comuns nas 3 unidades industriais.

Candida krusei: Torulopsis castellii (Candida castellii), Torulopsis haemulonii (Candida haemulonii) e Pichia ohmeri, apareceram tanto na 
Usina da Pedra como na Usina Santa Elisa e as espécies Candida entomophila e C. membranaefaciens foram detectadas na Usina da Pedra e na Destilaria Mandú.

Leveduras presentes exclusivamente na Usina da Pedra foram: Pichia membranaefaciens, $P$. guilliermondii e Schizosaccharomyces pombe. Já, as espécies Saccharomyces globosus (S. cerevisiae), S. beticus ( $S$. cerevisiae), S. capensis (S. cerevisiae), Candida parapsilosis, Torulopsis inconspicua (Candida inconspicua), Pichia etchellsii, P. spartinae, P. terricola (Issatchenkia terricola) e Trichosporon brassicae, foram detectadas somente na Usina Santa Elisa, enquanto Candida rhagii e Rhodotorula glutinis apareceram exclusivamente na Destilaria Mandú.

Particularmente, a Figura 6 demonstra a predominância das leveduras Saccharomyces cerevisiae: S. uvarum (S. cerevisiae): 34,95\%, Candida entomophila: 16,83\%, Saccharomyces coreanus (S. cerevisiae) e S. bayanus: ambas com $11,1 \%$, em relação as demais leveduras detectadas na Usina da Pedra, destacando-se principalmente, a espécie Saccharomyces cerevisiae: S. uvarum (S. cerevisiae). Esta última espécie apresentou-se também, como a levedura de maior incidência tanto na Usina Santa Elisa (32,79\%) como na Destilaria Mandú (35,3\%), destacando-se ainda, as espécies Torulopsis dattila (Kluyveromyces thermotolerans) na Usina Santa Elisa, com uma porcentagem de 18,24, bem como Candida entomophila e Saccharomyces bayanus na Destilaria Mandú, com porcentagens de 27,95 e 16,17, respectivamente (Figuras 7 e 8). Na literatura, o trabalho de Neder 
(1957), demonstra a predominância da espécie Saccharomyces cerevisiae dentro do gênero Saccharomyces, com uma freqüência de $71,6 \%$.

A espécie Saccharomyces cerevisiae: $S$. uvarum ( . cerevisiae), predominante nas 3 unidades industriais analisadas, apresentou freqüências semelhantes nas Usinas da Pedra, Santa Elisa e na Destilaria Mandú, ou seja, $34,95 \%, 32,79 \%$ e 35,3\%, respectivamente. Saccharomyces chevalieri ( $S$. cerevisiae), com freqüências de 4,16\% na Usina da Pedra, 5,45\% na Usina Santa Elisa e 2,94\% na Destilaria Mandú e Candida rugosa com freqüências de $1,38 \%$ na Usina da Pedra, $1,81 \%$ na Usina Santa Elisa e 1,47\% na Destilaria Mandú, também apresentaram valores similares nas 3 unidades industriais (Figuras 6,7 e 8, respectivamente), observando-se que as freqüências para estas duas espécies foram bastante inferiores em relação à espécie Saccharomyces cerevisiae: $S$. uvarum (S. cerevisiae).

A espécie Saccharomyces coreanus ( $S$. cerevisiae), também detectada nas 3 unidades industriais analisadas, apresentou freqüências semelhantes em apenas duas unidades, ou seja, 5,45\% na Usina Santa Elisa e 5,88\% na Destilaria Mandú, o mesmo acontecendo com a espécie Saccharomyces pretoriensis (Torulaspora pretoriensis), com freqüências de $1,81 \%$ e $1,47 \%$ nas mesmas unidades industriais, respectivamente (Figuras 7 e 8).

Nas Usinas da Pedra e Santa Elisa observou-se também, algumas leveduras com freqüências similares, sendo elas: Candida krusei: Torulopsis castellii (Candida castellii) com 2,7\% e 3,63\%, Torulopsis haemulonii (Candida haemulonii) com 1,38\% e 1,81\% e Pichia ohmeri, também com 
valores de $1,38 \%$ e $1,81 \%$, respectivamente (Figuras 6 e 7). Particularmente, a espécie Candida krusei mostrou-se como predominante dentro do gênero Candida, com freqüência de $58,1 \%$, em trabalho realizado por Neder (1957), sendo que Amorim et al. (1989), também relatam esta espécie como contaminante dominante durante o processo fermentativo em duas unidades industriais.

Candida membranaefaciens apresentou-se praticamente com a mesma freqüência na Usina da Pedra (1,38\%) e na Destilaria Mandú $(1,47 \%)$, como pode ser observado através das Figuras 6 e 8.

Analisando a Figura 6, é possível observar que todas as espécies de leveduras pertencentes aos gêneros Torulopsis e Pichia, apresentaram baixas freqüências de isolamento na Usina da Pedra, o mesmo ocorrendo com a espécie Schizosaccharomyces pombe.

Também, na Usina Santa Elisa, como demonstra a Figura 7, todas as espécies pertencentes ao gênero Pichia, além das pertencentes ao gênero Candida e a espécie Trichosporon brassicae, apresentaram-se com baixas freqüências. Na Destilaria Mandú é interessante ressaltar a ausência de leveduras do gênero Pichia e a baixa freqüência da espécie Rhodotorula glutinis, como pode ser observado através da Figura 8.

As baixas freqüências dos isolados pertencentes ao gênero Pichia nas Usinas da Pedra e Santa Elisa, estão de acordo com o trabalho de Neder (1957), onde o gênero Pichia, representado pela espécie $P$. membranaefaciens, demonstrou freqüência de apenas 1,2\%. 
Como na presente pesquisa as amostras não foram coletadas pensando-se em analisar a sobrevivência de leveduras ao longo dos processos de fermentação alcoólica, ou seja, caldo primário, caldo após tratamento térmico, melaço, mosto, vinho final, água no pé-de-cuba e leite de leveduras, toma-se difícil e muito arriscado tecer comentários a este respeito, razão pela qual somente serão discutidos aspéctos de freqüência e persistência ao longo da safra, das espécies identificadas em 3 etapas dos processos de produção de álcool.

Outra dificuldade apresentada, é que nas Usinas da Pedra e Santa Elisa o mosto é composto de caldo + melaço, o que traria dúvidas quanto ao fato de que a detecção de uma determinada levedura no caldo e no mosto, estaria relacionada à resistência da levedura ao tratamento térmico do caldo ou a recontaminação do mosto através da adição do melaço.

Assim, devido aos 2 fatos expostos (seqüência de amostragem não adequada ao estudo de sobrevivência das leveduras e composição do mosto), não serão discutidos aspéctos de resistência/sobrevivência, bem como possíveis pontos de introdução das leveduras contaminantes ao longo dos processos fermentativos.

Pela análise das Tabelas 3, 4 e 5, nota-se que uma grande variedade de espécies de leveduras, pertencentes a diferentes gêneros, normalmente encontra-se presente no caldo primário, mostrando, como comprovam os relatos na literatura sobre o assunto, que o solo, a própria cana, a colheita, o transporte, o armazenamento, a água de embebição e a moenda, contribuem no incremento da população microbiana no caldo de cana. A partir daí, 
muitas leveduras suportam as condições adversas de tratamento térmico, temperatura na fermentação, teor alcoólico, acidez elevada, metabólitos de outros contaminantes, etc. e chegam viáveis ao vinho final e ao leite de leveduras no pé-de-cuba. Outras, não suportando tais condições adversas do processo de fermentação alcoólica, desaparecem, dando lugar a outros contaminantes introduzidos através de inúmeros pontos críticos, que se constituem em importantes focos de contaminação ao longo das diferentes etapas do processo.

Como pode ser observado pela análise da Figura 9, que demonstra as porcentagens dos isolados identificados no caldo primário na Usina da Pedra, a espécie Candida entomophila apresentou-se como a levedura de maior incidência, com freqüência de $30 \%$, seguida pelas espécies: Saccharomyces cerevisiae: $S$. uvarum (S. cerevisiae), $16,6 \%$ e $S$. coreanus (S. cerevisiae), 13,4\%. Em trabalho de Shehata (1960), Saccharomyces cerevisiae é relatada como uma das espécies predominantes no caldo de cana. As demais leveduras detectadas neste ponto (Figura 9), apresentaram freqüências inferiores, sendo elas: Saccharomyces bayanus, Candida krusei: Torulopsis castellii (Candida castellii), Torulopsis dattila (Kluyveromyces thermotolerans), Pichia membranaefaciens, com 6,6\% cada e Candida membranaefaciens, C. rugosa, Torulopsis haemulonii (Candida haemulonii), Pichia guilliermondii, com freqüências de 3,4\% cada. Apesar das baixas freqüências apresentadas neste ponto pelas espécies Candida krusei: Torulopsis castellii (Candida castellii) e Pichia membranaefaciens, o trabalho de Shehata (1960), relata Candida krusei e Pichia 
membranaefaciens como algumas das espécies predominantes no caldo de cana.

Já, no mosto, predominou a espécie Saccharomyces cerevisiae: $S$. uvarum (S. cerevisiae), com uma porcentagem de 42,86, seguida da levedura S. coreanus (S. cerevisiae) com freqüência de $28,58 \%$. Saccharomyces chevalieri (S. cerevisiae) e Schizosaccharomyces pombe, também detectadas no mosto, apresentaram freqüências iguais, ou seja, 14,28\% (Figura 10). No mosto em fermentação, Shehata (1960), relata as espécies Saccharomyces cerevisiae e Schizosaccharomyces pombe, como predominantes neste ponto.

Também, como pode ser observado através da Figura 11, a espécie Saccharomyces cerevisiae: S. uvarum (S. cerevisiae) apresentou-se como dominante no leite de leveduras, com frequiência de $50 \%$, seguida pelas espécies: $S$. bayanus, $21,44 \%$, S. pretoriensis (Torulaspora pretoriensis) e Candida entomophila, ambas com 10,71\% cada. Saccharomyces chevalieri (S. cerevisiae) e Pichia ohmeri, foram identificadas com 3,57\% cada. Em pesquisa realizada por Basso et al. (1993), os autores relatam a dominância das leveduras Saccharomyces cerevisiae e $S$. chevalieri como contaminantes em amostras de fermento em uma unidade industrial, à despeito da levedura $S$. chevalieri ( $S$. cerevisiae) ter apresentado baixa freqüência no leite de leveduras na Usina da Pedra.

É importante mencionar que, a Usina da Pedra utilizou uma mistura de leveduras para iniciar o processo de produção de álcool durante a safra de 94/95, mistura esta, composta pelas espécies Saccharomyces cerevisiae e $S$. 
bayanus. Assim, como pode ser observado através da Figura 11, Saccharomyces cerevisiae: S. uvarum (S. cerevisiae) e $S$. bayanus foram detectadas com elevadas freqüências no leite de leveduras desta unidade industrial, podendo tal fato, relacionar-se às leveduras do processo.

Pela análise global das porcentagens dos isolados nestes 3 pontos amostrados (Figuras 9, 10 e 11), observa-se a elevada freqüência da espécie Saccharomyces cerevisiae: S. uvarum (S. cerevisiae), presente nestes 3 pontos e dominante em 2 deles. Saccharomyces coreanus (S. cerevisiae) com freqüência relativamente elevada no caldo primário, teve sua porcentagem dobrada no mosto e não foi detectada no leite de leveduras. A levedura Saccharomyces bayanus, apesar da baixa freqüência no caldo primário e ausência no mosto, apresentou freqüência bastante significativa no leite de leveduras, o contrário acontecendo com a espécie Candida entomophila, com elevada freqüência no caldo primário, reduzindo significativamente este valor no leite de leveduras. Saccharomyces chevalieri ( $S$. cerevisiae), com freqüência relativamente elevada no mosto, apresentou-se com valor bastante reduzido no leite de leveduras. Vale ressaltar ainda, as freqüências significativas das espécies: Schizosaccharomyces pombe, esta presente somente no mosto e Saccharomyces pretoriensis (Torulaspora pretoriensis), presente apenas no leite de leveduras.

A análise global destes 3 pontos amostrados (caldo primário, mosto e leite de leveduras) na Usina da Pedra, revela ainda, uma maior diversidade de leveduras detectada no caldo primário em relação ao mosto e ao leite de 
leveduras desta unidade industrial (Figuras 9, 10 e 11), o que pode ser explicado pelas condições drásticas do processo de produção de álcool, em relação a tratamento térmico do caldo, teor alcoólico na dorna de fermentação, acidez no pé-de-cuba, metabólitos de outros contaminantes, etc., que certamente são responsáveis pela destruição e/ou inativação de muitas leveduras que chegam com a matéria-prima na indústria.

A análise da Figura 12, que demonstra as porcentagens dos isolados identificados no caldo primário na Usina Santa Elisa, indica a espécie Torulopsis dattila (Kluyveromyces thermotolerans), como a levedura dominante neste ponto, com freqüência de $31,25 \%$, seguida da espécie Saccharomyces cerevisiae: S. uvarum (S. cerevisiae), com freqüência de $25 \%$. Saccharomyces cerevisiae é uma das espécies relatada por Shehata (1960), como predominante no caldo de cana, concordando com a alta freqüência encontrada na presente pesquisa para esta espécie. Todas as demais leveduras detectadas no caldo primário (Figura 12), apresentaram freqüências iguais e bastante inferiores em relação às duas primeiras, ou seja, 6,25\% cada, sendo elas: Saccharomyces globosus (S. cerevisiae), $S$. capensis (S. cerevisiae), Candida parapsilosis, C. krusei: Torulopsis castellii (Candida castellii), Torulopsis inconspicua (Candida inconspicua), Pichia spartinae e P. ohmeri. Apesar de Candida krusei: Torulopsis castellii (Candida castellii) ter apresentado baixa freqüência neste ponto, o trabalho de Shehata (1960), relata a espécie Candida krusei como uma das predominantes no caldo de cana. O mesmo autor cita a identificação, também a partir de caldo de cana, da espécie Candida parapsilosis var. 
intermedia, em baixa freqüência, o que concorda com os resultados da presente pesquisa, onde Candida parapsilosis foi identificada com porcentual de 6,25 (Figura 12).

Torulopsis dattila (Kluyveromyces thermotolerans), foi também a levedura de maior incidência no mosto, com freqüência de $26,6 \%$, novamente seguida pela espécie Saccharomyces cerevisiae: S. uvarum ( $S$. cerevisiae), com freqüência de $20 \%$ (Figura 13). No trabalho de Shehata (1960), as amostras de mosto em fermentação, revelaram a espécie Saccharomyces cerevisiae como uma das espécies predominantes neste ponto. No presente trabalho, Saccharomyces coreanus (S. cerevisiae) e Pichia etchellsii apresentaram freqüências relativamente elevadas, com valores de $13,5 \%$ cada. As demais leveduras presentes no mosto apresentaram freqüências iguais e inferiores, com valores de $6,6 \%$ cada, sendo elas: Saccharomyces chevalieri (S. cerevisiae), S. bayanus, Torulopsis haemulonii (Candida haemulonii) e Trichosporon brassicae (Figura 13).

Contudo, como mostra a Figura 14, a espécie Saccharomyces cerevisiae: $S$. uvarum ( $S$. cerevisiae), foi o grande destaque no leite de leveduras, com freqüência de $45,96 \%$, freqüência esta, muito superior a das demais leveduras detectadas neste ponto, à saber: Saccharomyces chevalieri (S. cerevisiae) e $S$. bayanus, com $8,3 \%$ cada, S. coreanus (S. cerevisiae), $S$. globosus ( $S$. cerevisiae), S. beticus ( $S$. cerevisiae), S. pretoriensis (Torulaspora pretoriensis), Candida rugosa, C. krusei: Torulopsis castellii (Candida castellii), Torulopsis dattila (Kluyveromyces thermotolerans), 
Pichia terricola (Issatchenkia terricola) e Trichosporon brassicae, todas com freqüência de $4,16 \%$ cada. Saccharomyces cerevisiae e $S$. chevalieri são relatadas por Basso et al. (1993), como leveduras contaminantes dominantes em amostras de fermento em uma unidade industrial, apresentando-se ainda, a levedura $S$. coreanus numa proporção de até $10 \%$. Entretanto, como demonstra a Figura 14, a levedura Saccharomyces chevalieri (S. cerevisiae) apresentou-se com baixa freqüência $(8,3 \%)$ no leite de leveduras nesta unidade industrial pesquisada.

A Usina Santa Elisa também utilizou-se da mistura de leveduras composta pelas espécies Saccharomyces cerevisiae e S. bayanus para iniciar o processo de produção de álcool durante a safra de 94/95. Conforme demonstra a Figura 14, Saccharomyces cerevisiae: S. uvarum (S. cerevisiae) e $S$. bayanus foram detectadas no leite de leveduras desta unidade industrial, podendo relacionar-se às leveduras do processo, neste caso principalmente, no que se refere à levedura Saccharomyces cerevisiae: S. uvarum ( $S$. cerevisiae).

Pela análise global das porcentagens dos isolados nestes 3 pontos amostrados (Figuras 12, 13 e 14), observa-se as elevadas frequiências das espécies Saccharomyces cerevisiae: S. uvarum (S. cerevisiae) e Torulopsis dattila (Kluyveromyces thermotolerans), sendo a primeira levedura, dominante absoluta no leite de leveduras, estando porém, também presente em elevadas proporções tanto no caldo primário como no mosto. Já, a espécie Torulopsis dattila (Kluyveromyces thermotolerans), dominante tanto no caldo primário como no mosto, apresentou drástica redução no leite de 
leveduras. A espécie Saccharomyces coreanus ( $S$. cerevisiae), com freqüência relativamente elevada no mosto, apresentou redução significativa no leite de leveduras e Pichia etchellsii, também com freqüência relativamente elevada no mosto, somente foi detectada neste ponto. As espécies Saccharomyces globosus (S. cerevisiae) e Candida krusei: Torulopsis castellii (Candida castellii), mantiveram suas baixas freqüências nos 2 pontos de detecção, ou seja, caldo primário e leite de leveduras, o mesmo ocorrendo com as espécies Saccharomyces chevalieri ( $S$. cerevisiae), S. bayanus e Trichosporon brassicae, detectadas no mosto e no leite de leveduras.

A análise global destes 3 pontos amostrados (caldo primário, mosto e leite de leveduras) na Usina Santa Elisa, revela ainda, que no leite de leveduras foi detectado uma maior diversidade de leveduras em relação ao caldo primário e ao mosto, sugerindo recontaminações nas etapas finais do processo, uma vez que, algumas leveduras identificadas no leite de leveduras, nunca foram detectadas no caldo e mosto na safra analisada.

Outro fato que pode ser observado, mesmo que a seqüência das amostras não tenha sido feita pensando-se em estudar a sobrevivência das leveduras ao longo do processo fermentativo, como já mencionado anteriormente, é a identificação de várias espécies de leveduras apenas nas amostras de caldo primário e nunca nas amostras de mosto e de leite de leveduras, constituindo-se tal fato, numa evidência de que estas leveduras não suportaram as condições adversas nas etapas subseqüentes do processo. 
Como pode ser observado pela análise da Figura 15, que demonstra a porcentagem dos isolados identificados no caldo primário na Destilaria Mandú, a espécie Candida entomophila apresentou-se como dominante absoluta neste ponto, com freqüência de $60 \%$. As demais leveduras presentes no caldo primário, apresentaram freqüências bastante inferiores em relação à Candida entomophila, ou seja: Saccharomyces cerevisiae: $S$. uvarum (S. cerevisiae) e S. coreanus (S. cerevisiae), 12\% cada, Torulopsis dattila (Kluyveromyces thermotolerans), 8\%, Saccharomyces bayanus e Candida rugosa, $4 \%$ cada. À despeito da freqüência bastante inferior da espécie Saccharomyces cerevisiae: S. uvarum (S. cerevisiae) em relação à levedura dominante neste ponto, $S$. cerevisiae aparece em trabalho de Shehata (1960), como uma das espécies predominantes no caldo de cana, como já mencionado anteriormente.

Entretanto, no mosto, a espécie Saccharomyces cerevisiae: $S$. uvarum (S. cerevisiae), com freqüência de $53,86 \%$, dominou em relação as demais leveduras presentes neste ponto, as quais apresentaram freqüências inferiores, à saber: Saccharomyces bayanus, 15,38\%, Candida entomophila, 11,55\%, Saccharomyces chevalieri (S. cerevisiae), 7,69\% e Candida membranaefaciens, Torulopsis dattila (Kluyveromyces thermotolerans), Rhodotorula glutinis, com 3,84\% cada (Figura 16). Novamente o trabalho de Shehata (1960), pode ser mencionado, uma vez que, apesar da utilização de amostras de mosto em fermentação, a espécie Saccharomyces cerevisiae apresentou-se como uma das predominantes neste ponto. 
A Figura 17 demonstra que a espécie Saccharomyces cerevisiae: $S$. uvarum ( $S$. cerevisiae) foi também a levedura de maior incidência no leite de leveduras, com porcentagem de 41,18 , seguida pela espécie $S$. bayanus, com $35,3 \%$, freqüência esta, bastante próxima da obtida pela levedura $S$. cerevisiae: S. uvarum (S. cerevisiae). As demais leveduras presentes no leite de leveduras apresentaram freqüências iguais e bastante inferiores em relação às duas primeiras, com valores de 5,88\% cada, sendo elas: Saccharomyces coreanus (S. cerevisiae), S. pretoriensis (Torulaspora pretoriensis), Candida entomophila e C. rhagii. Como citado anteriormente, o trabalho de Basso et al. (1993), demonstra que em uma unidade industrial a levedura Saccharomyces cerevisiae apresentou-se como uma das contaminantes dominantes e a levedura $S$. coreanus, apresentou-se numa proporção de até $10 \%$ em amostras de fermento.

Igualmente como ocorrido nas Usinas da Pedra e Santa Elisa, também a Destilaria Mandú utilizou-se da mistura de leveduras composta pelas espécies Saccharomyces cerevisiae e S. bayanus, para iniciar o processo de produção de álcool na safra de 94/95. Analisando a Figura 17, observamos a deteç̧ão de Saccharomyces cerevisiae: $S$. uvarum ( $S$. cerevisiae) e $S$. bayanus no leite de leveduras desta unidade industrial em elevadas proporções, podendo relacionar-se às leveduras do processo.

Pela análise global das porcentagens dos isolados nestes 3 pontos amostrados (Figuras 15, 16 e 17), observa-se grande incidência das leveduras Saccharomyces cerevisiae: S. uvarum (S. cerevisiae) e Candida entomophila. Contudo, a espécie Saccharomyces cerevisiae: S. uvarum ( $S$. 
cerevisiae), cuja freqüência no caldo primário foi bastante reduzida, passou a ser a levedura dominante tanto no mosto como no leite de leveduras, o contrário acontecendo com a espécie Candida entomophila, que dominava absoluta no caldo primário, tendo porém, sua freqüência sensivelmente reduzida tanto no mosto como no leite de leveduras. A levedura Saccharomyces coreanus (S. cerevisiae), que já apresentava baixa freqüência no caldo primário, teve seus valores reduzidos em praticamente à metade no leite de leveduras, o mesmo ocorrendo com a espécie Torulopsis dattila (Kluyveromyces thermotolerans) em relação ao caldo primário e ao mosto. Já, a espécie Saccharomyces bayanus, cuja freqüência no caldo primário era também bastante reduzida, apresentou aumento em sua porcentagem tanto no mosto como no leite de leveduras, tal que, neste último ponto, sua freqüência aproximou-se bastante em relação à levedura dominante deste mesmo ponto, fato já explicado em função da utilização desta espécie na mistura de leveduras utilizada para o início da safra.

Da mesma forma que se discutiu anteriormente, a levedura Candida rugosa foi identificada apenas em amostras de caldo primário, o que leva a suspeitar de sua sensibilidade às condições adversas nas etapas seguintes do processo fermentativo.

A análise global destes 3 pontos amostrados (caldo primário, mosto e leite de leveduras) na Destilaria Mandú, revela ainda, que todos os pontos amostrados apresentaram-se similares quanto a diversidade de leveduras nesta unidade industrial, embora algumas diferenças com relação às espécies identificadas tenham ocorrido (Figuras 15, 16 e 17). 
Analisando as Figuras 9, 12 e 15, que demonstram as porcentagens dos isolados identificados no caldo primário nas Usinas da Pedra, Santa Elisa e na Destilaria Mandú, respectivamente, observa-se que a espécie Candida entomophila apresentou-se como a levedura dominante neste ponto, tanto na Usina da Pedra como na Destilaria Mandú, não estando presente na Usina Santa Elisa. As freqüências da espécie Saccharomyces cerevisiae: $S$. uvarum (S. cerevisiae), foram relativamente próximas nas Usinas da Pedra e Santa Elisa, tendo contudo, valor inferior na Destilaria Mandú. A espécie Saccharomyces coreanus (S. cerevisiae), apresentou freqüências bastante similares na Usina da Pedra e na Destilaria Mandú, não sendo detectada na Usina Santa Elisa, sendo tal fato também válido para as espécies Saccharomyces bayanus e Candida rugosa. Já a levedura Candida krusei: Torulopsis castellii (Candida castellii), ausente na Destilaria Mandú, apresentou praticamente a mesma freqüência nas Usinas da Pedra e Santa Elisa. A espécie Torulopsis dattila (Kluyveromyces thermotolerans), dominante na Usina Santa Elisa, apresentou-se com freqüências similares, porém bastante reduzidas, na Usina da Pedra e na Destilaria Mandú.

Analisando-se ainda estas mesmas Figuras (9, 12 e 15), nota-se que existem algumas diferenças em relação à certas espécies de leveduras encontradas no caldo primário que somente aparecem em uma das 3 unidades amostradas, o que pode mostrar particularidades destas unidades quanto a clima, solo, variedade de cana, colheita, transporte, armazenamento, etc. 
A análise das Figuras 10, 13 e 16, que indicam as porcentagens dos isolados identificados no mosto nas Usinas da Pedra, Santa Elisa e Destilaria Mandú, respectivamente, revela que a espécie Saccharomyces cerevisiae: $S$. uvarum (S. cerevisiae) apresentou-se como a levedura dominante tanto na Usina da Pedra como na Destilaria Mandú, tendo ainda, freqüência bastante elevada na Usina Santa Elisa, apresentando-se inferior apenas à espécie Torulopsis dattila (Kluyveromyces thermotolerans) que foi a levedura de maior incidência nesta unidade industrial em amostras de mosto. Porém, Torulopsis dattila (Klugveromyces thermotolerans), ao contrário do ocorrido na Usina Santa Elisa, apresentou baixa frequeência na Destilaria Mandú e não foi detectada em amostras de mosto na Usina da Pedra. A espécie Saccharomyces coreanus (S. cerevisiae) revelou freqüência superior na Usina da Pedra em comparação com a Usina Santa Elisa, não estando presente na Destilaria Mandú. Saccharomyces chevalieri (S. cerevisiae) também apresentou freqüência superior na Usina da Pedra em relação à Usina Santa Elisa e à Destilaria Mandú, sendo que nestas duas últimas unidades industriais, as freqüências foram bastante próximas para esta levedura $(6,6 \%$ e $7,69 \%$, respectivamente). Finalmente, a freqüência da espécie Saccharomyces bayanus na Destilaria Mandú foi maior que a freqüência obtida na Usina Santa Elisa, não sendo tal levedura detectada na Usina da Pedra.

Aqui também algumas leveduras somente foram identificadas em apenas uma das 3 unidades amostradas, o que pode evidenciar diferentes tratamentos térmicos do caldo, bem como diferenças na composição do 
mosto utilizado para a fermentação, além de outros fatores ou pontos críticos de contaminação entre caldo primário e mosto.

Já, pela análise das Figuras 11, 14 e 17, que demonstram as porcentagens dos isolados no leite de leveduras nas Usinas da Pedra, Santa Elisa e na Destilaria Mandú, respectivamente, verifica-se que a espécie Saccharomyces cerevisiae: $S$. uvarum (S. cerevisiae) foi a levedura dominante nas 3 unidades industriais, como era esperado. A espécie Saccharomyces bayanus apresentou elevada incidência, tanto na Usina da Pedra como na Destilaria Mandú, porém na Usina Santa Elisa, tal levedura revelou freqüência bastante reduzida. Saccharomyces chevalieri ( $S$. cerevisiae) apresentou-se com baixas freqüências tanto na Usina da Pedra como na Usina Santa Elisa, estando tal espécie ausente nas amostras de leite de leveduras na Destilaria Mandú. Saccharomyces coreanus (S. cerevisiae), ausente na Usina da Pedra, revelou freqüências bastante próximas, porém baixas, na Usina Santa Elisa e na Destilaria Mandú. Também, a espécie Saccharomyces pretoriensis (Torulaspora pretoriensis) apresentou freqüências bastante similares, porém baixas, na Usina Santa Elisa e na Destilaria Mandú, apresentando, contudo, porcentagem mais elevada na Usina da Pedra. Finalmente, a levedura Candida entomophila apresentou-se com freqüência superior na Usina da Pedra em relação à Destilaria Mandú, estando ausente na Usina Santa Elisa.

Analisando globalmente as Figuras 9, 12 e 15, observa-se que as amostras de caldo primário tanto na Usina da Pedra (Figura 9) como na Usina Santa Elisa (Figura 12), revelaram grande diversidade de espécies, 
sendo que na Destilaria Mandú esta diversidade foi menos acentuada neste ponto (Figura 15).

Realizando a mesma análise através das Figuras 10, 13 e 16, verifica-se grande diversidade de espécies de leveduras no mosto na Usina Santa Elisa (Figura 13) e na Destilaria Mandú (Figura 16), sendo que o mesmo ponto de amostragem na Usina da Pedra (Figura 10) apresentou-se pouco diversificado quando comparado com as outras unidades industriais.

Já, a análise das Figuras 11, 14 e 17, demonstra a grande diversidade de leveduras detectada no leite de leveduras na Usina Santa Elisa (Figura 14) em comparação com este mesmo ponto de amostragem na Usina da Pedra (Figura 11) e na Destilaria Mandú (Figura 17), estas duas últimas unidades industriais apresentando-se similares quanto à diversidade de leveduras.

Analisando ainda as Figuras 9, 10 e 11, fica fácil observar os gêneros de leveduras presentes em cada ponto amostrado na Usina da Pedra. Assim, verifica-se no caldo primário (Figura 9), a presença dos seguintes gêneros: Saccharomyces, Candida, Torulopsis e Pichia. Já, no mosto (Figura 10), apenas os gêneros Saccharomyces e Schizosaccharomyces estiveram presentes, enquanto que no leite de leveduras (Figura 11) detectou-se os gêneros Saccharomyces, Candida e Pichia.

Observa-se, portanto, a presença do gênero Saccharomyces nos 3 pontos amostrados, enquanto os gêneros Candida e Pichia foram detectados em 2 pontos, ou seja, no caldo primário e no leite de leveduras. Já, o gênero 
Torulopsis apareceu exclusivamente no caldo primário e o gênero Schizosaccharomyces, exclusivamente no mosto.

Realizando a mesma análise na Usina Santa Elisa através da observação das Figuras 12, 13 e 14, verifica-se a presença dos gêneros Saccharomyces, Candida, Torulopsis e Pichia no caldo primário (Figura 12), enquanto que no mosto (Figura 13), observa-se a detecção dos gêneros Saccharomyces, Torulopsis, Pichia e Trichosporon. Já, no leite de leveduras, estiveram presentes os mesmos gêneros detectados no caldo primário, acrescidos do gênero Trichosporon (Figura 14).

Desta forma, observa-se que os gêneros Saccharomyces, Torulopsis e Pichia, foram detectados nos 3 pontos amostrados, enquanto os gêneros Candida e Trichosporon apareceram apenas em 2 pontos, à saber: gênero Candida detectado no caldo primário e no leite de leveduras e gênero Trichosporon no mosto e no leite de leveduras.

Os gêneros de leveduras detectados em cada ponto amostrado na Destilaria Mandú, podem ser observados pela análise das Figuras 15, 16 e 17. Assim, verifica-se no caldo primário (Figura 15), a presença dos seguintes gêneros: Saccharomyces, Candida e Torulopsis. Estes 3 gêneros também foram detectados no mosto, além do gênero Rhodotorula (Figura 16). Já, no leite de leveduras (Figura 17), apenas os gêneros Saccharomyces e Candida estiveram presentes. Observa-se, portanto, a presença dos gêneros Saccharomyces e Candida nos 3 pontos amostrados. Já, o gênero Torulopsis foi detectado em 2 pontos, ou seja, no caldo primário e no mosto, enquanto que o gênero Rhodotorula apareceu exclusivamente no mosto. 
Comparando-se ainda, cada ponto amostrado (caldo primário, mosto e leite de leveduras) entre as 3 unidades industriais pesquisadas, verifica-se que tanto a Usina da Pedra como a Usina Santa Elisa apresentaram os mesmos gêneros de leveduras no caldo primário, ou seja, Saccharomyces, Candida, Torulopsis e Pichia, sendo que na Destilaria Mandú houve ausência apenas do gênero Pichia neste ponto, em comparação com as outras duas unidades industriais (Figuras 9, 12 e 15).

Analisando as Figuras 10, 13 e 16, observa-se que o gênero Saccharomyces esteve presente no mosto das 3 unidades industriais e o gênero Torulopsis foi comum na Usina Santa Elisa e na Destilaria Mandú. Contudo, o gênero Schizosaccharomyces apareceu apenas na Usina da Pedra, enquanto os gêneros Pichia e Trichosporon foram exclusivos da Usina Santa Elisa, o mesmo ocorrendo com os gêneros Candida e Rhodotorula na Destilaria Mandú.

Com relação ao leite de leveduras das 3 unidades industriais, verifica-se pela análise das Figuras 11, 14 e 17, que os gêneros Saccharomyces, Candida e Pichia, foram comuns nas Usinas da Pedra e Santa Elisa, estando os 2 primeiros gêneros também presentes na Destilaria Mandú. Os gêneros Torulopsis e Trichosporon apareceram exclusivamente na Usina Santa Elisa.

Analisando as leveduras presentes nas amostragens mensais de caldo primário, observa-se através da Tabela 6, que a espécie Candida entomophila foi detectada em todas as amostragens mensais na Usina da Pedra, indicando, portanto, sua constante introdução no processo, 
provavelmente com a chegada da cana-de-açúcar à indústria e/ou através da água de lavagem da cana. Também, a espécie Saccharomyces cerevisiae: $S$. uvarum (S. cerevisiae) foi detectada na maior parte das amostragens mensais de caldo primário, estando ausente apenas nas $1^{\mathrm{a}}$ e $4^{\mathrm{a}}$ amostragens mensais, correspondendo, respectivamente, aos meses de maio e agosto. Destaque ainda, pode ser dado à levedura Saccharomyces coreanus (S. cerevisiae) a qual foi detectada em 3 das 6 amostragens mensais de caldo primário realizadas nesta unidade industrial, amostragens estas, correspondendo aos meses de junho, julho e setembro. Vale ressaltar, a grande diversidade de espécies e gêneros de leveduras presente nas amostragens de caldo primário na Usina da Pedra. Particularmente, tal diversidade foi mais acentuada nas 3 primeiras amostragens mensais, correspondendo aos meses de maio, junho e julho. Nota-se também, pela análise da Tabela 6 , que as $2^{\mathrm{a}}$ e $3^{\mathrm{a}}$ amostragens mensais (meses de junho e julho, respectivamente) apresentaram praticamente as mesmas espécies de leveduras, fato também observado entre as duas últimas amostragens mensais de caldo primário, correspondendo aos meses de setembro e outubro, respectivamente. Particularmente, as leveduras detectadas nestas duas últimas amostragens mensais também estiveram presentes nas $2^{\mathrm{a}}$ e $3^{\mathrm{a}}$ amostragens mensais de caldo primário.

Também, nas amostragens mensais de mosto desta mesma unidade industrial (Tabela 7), destaca-se a presença da espécie Saccharomyces cerevisiae: S. uvarum (S. cerevisiae) detectada nas 3 primeiras amostragens mensais, correspondendo aos meses de maio, junho e julho, indicando a persistência de uma provável recontaminação do mosto, possíveis falhas no 
tratamento térmico do caldo em processo ou resistência térmica das leveduras. A levedura Schizosaccharomyces pombe, detectada nas duas últimas amostragens mensais de mosto, respectivamente nos meses de setembro e outubro, foi a única espécie presente nestas amostragens. Ao contrário do ocorrido nas amostragens mensais de caldo primário, pouca diversidade de espécies e, principalmente de gêneros de leveduras, foi observada nas amostragens mensais de mosto na Usina da Pedra. Nota-se ainda, que as espécies de leveduras detectadas nas $1^{a}$ e $2^{a}$ amostragens mensais de mosto (respectivamente meses de maio e junho), estiveram presentes na $3^{\mathrm{a}}$ amostragem, correspondente ao mês de julho, tornando esta $3^{\mathrm{a}}$ amostragem bastante similar em relação às duas primeiras.

Não houve deteç̧ão de leveduras a partir da amostra de mosto referente ao mês de agosto na Usina da Pedra (Tabela 7), devido ao não crescimento celular durante o cultivo das culturas brutas de leveduras a partir de tal amostra. Um pré-enriquecimento da amostra de mosto, inoculando-se $1 \mathrm{~mL}$ da amostra em $5 \mathrm{~mL}$ de caldo YEPD esterilizado, foi realizado na tentativa de se obter a recuperação de leveduras, não havendo, contudo, nenhum crescimento.

Como pode ser observado através da Tabela 8, a levedura Saccharomyces cerevisiae: $S$. uvarum (S. cerevisiae) foi também a levedura de principal persistência ao longo das amostragens mensais de leite de leveduras na Usina da Pedra, estando ausente apenas na $2^{a}$ amostragem mensal (mês de junho). Observa-se também, diversidade de espécies e gêneros de leveduras ao longo destas amostragens, porém inferior àquela 
presente nas amostragens mensais de caldo primário desta mesma unidade industrial. Particularmente, a $1^{\mathrm{a}}$ amostragem mensal (mês de maio) apresentou uma maior variedade de espécies e gêneros de leveduras. A análise da Tabela 8 indica ainda, que as leveduras detectadas na $2^{\mathrm{a}}$ amostragem mensal (mês de junho), também estiveram presentes na $1^{\text {a }}$ amostragem (mês de maio). A mesma espécie de levedura foi detectada nas $3^{\mathrm{a}}$ e $5^{\mathrm{a}}$ amostragens mensais de leite de leveduras (meses de julho e setembro, respectivamente), sendo a única espécie presente nestas amostragens. Finalmente as $4^{\mathrm{a}}$ e $6^{\mathrm{a}}$ amostragens mensais (meses de agosto e outubro, respectivamente), apresentaram praticamente as mesmas espécies de leveduras.

Pela análise da Tabela 9, que relaciona as leveduras presentes nas amostragens mensais de caldo primário na Usina Santa Elisa, destaca-se a presença da levedura Torulopsis dattila (Kluyveromyces thermotolerans) detectada nas duas primeiras amostragens mensais, correspondendo aos meses de maio e junho, bem como na última amostragem, correspondendo ao mês de outubro, demonstrando, portanto, certa constância na introdução de tal levedura no processo. A espécie Saccharomyces cerevisiae: $S$. uvarum ( $S$. cerevisiae) foi detectada apenas nas duas últimas amostragens mensais de caldo primário (meses de setembro e outubro). Nota-se ainda, diversidade de espécies e gêneros de leveduras nas amostragens de caldo primário na Usina Santa Elisa, particularmente observada nas $2^{\mathrm{a}}, 3^{\mathrm{a}}$ e $5^{\mathrm{a}}$ amostragens mensais, que correspondem, respectivamente, aos meses de junho, agosto e outubro. 
Não houve detecção de leveduras a partir da amostra de caldo primário referente ao mês de julho na Usina Santa Elisa (Tabela 9), devido ao não crescimento celular durante o cultivo das culturas brutas de leveduras a partir de tal amostra. Um pré-enriquecimento da amostra de caldo primário, inoculando-se $1 \mathrm{~mL}$ da amostra em $5 \mathrm{~mL}$ de caldo YEPD esterilizado, foi realizado na tentativa de se obter a recuperação de leveduras, não havendo, contudo, nenhum crescimento.

Analisando as leveduras presentes nas amostragens mensais de mosto na Usina Santa Elisa (Tabela 10), destaca-se no geral, as mesmas circunstâncias citadas nas amostragens mensais de caldo primário desta Usina, ou seja, a presença da levedura Torulopsis dattila (Kluyveromyces thermotolerans) detectada, agora, nas 3 primeiras amostragens mensais, correspondendo aos meses de junho, julho e agosto, bem como a presença da espécie Saccharomyces cerevisiae: S. uvarum (S. cerevisiae), também nas duas últimas amostragens mensais de mosto (meses de setembro e outubro). Diversidade de espécies e gêneros de leveduras foram também observadas nestas amostragens, particularmente na $1^{\text {a }}$ amostragem mensal, que corresponde ao mês de junho. É possível observar ainda, que as duas últimas amostragens mensais (meses de setembro e outubro), revelaram similaridade entre si, com relação às espécies de leveduras detectadas.

Igualmente como ocorrido com a amostragem de caldo primário referente ao mês de julho na Usina Santa Elisa, também não houve detecção de leveduras a partir da amostra de mosto referente ao mês de maio nesta 
mesma unidade industrial (Tabela 10), seguindo as mesmas justificativas apontadas anteriormente.

A levedura Saccharomyces cerevisiae: $S$. uvarum (S. cerevisiae) destacou-se pela persistência apresentada ao longo das amostragens mensais de leite de leveduras na Usina Santa Elisa (Tabela 11), estando tal levedura, ausente apenas na $1^{\mathrm{a}}$ amostragem mensal, que corresponde ao mês de maio. Assim como as amostragens de caldo primário e mosto, também as amostragens mensais de leite de leveduras desta unidade industrial, apresentaram diversidade de espécies e gêneros de leveduras, principalmente observada nas $2^{\mathrm{a}}, 3^{\mathrm{a}}, 4^{\mathrm{a}}$ e $5^{\mathrm{a}}$ amostragens mensais, que correspondem respectivamente, aos meses de junho, julho, agosto e setembro. Nota-se ainda, que nas $4^{\mathrm{a}}$ e $6^{\mathrm{a}}$ amostragens mensais (meses de agosto e outubro), foram detectadas praticamente as mesmas espécies de leveduras.

Pela análise dá Tabela 12, que relaciona as leveduras presentes nas amostragens mensais de caldo primário na Destilaria Mandú, observa-se a constante introdução da levedura Candida entomophila no processo, estando tal levedura ausente apenas na última amostragem mensal de caldo primário, ou seja, no mês de outubro. As espécies Saccharomyces coreanus ( $S$. cerevisiae) e $S$. cerevisiae: $S$. uvarum (S. cerevisiae) apresentaram certa persistência ao longo das amostragens de caldo primário, pois ambas estiveram presentes em 3 das 6 amostragens mensais realizadas nesta unidade industrial, sendo a primeira espécie, detectada nas $1^{\mathrm{a}}, 2^{\mathrm{a}}$ e $4^{\mathrm{a}}$ amostragens mensais, correspondendo respectivamente, aos meses de maio, junho e agosto, enquanto que a segunda espécie, esteve presente nas $3^{\mathrm{a}}, 5^{\mathrm{a}} \mathrm{e}$ 
$6^{\mathrm{a}}$ amostragens mensais, correspondendo respectivamente, aos meses de julho, setembro e outubro. Verifica-se também, nas amostragens de caldo primário desta unidade industrial, diversidade de espécies e gêneros de leveduras, destacando-se as $2^{\mathrm{a}}, 3^{\mathrm{a}}$ e $5^{\mathrm{a}}$ amostragens mensais, que correspondem respectivamente, aos meses de junho, julho e setembro. Particularmente, nas $1^{\mathrm{a}}$ e $4^{\mathrm{a}}$ amostragens mensais (meses de maio e agosto), detectou-se as mesmas espécies de leveduras e a $2^{\mathrm{a}}$ amostragem mensal (mês de junho), apresentou praticamente as mesmas leveduras em relação à estas duas amostragens citadas. É possível observar ainda, que a $3^{\mathrm{a}}$ amostragem mensal de caldo primário, correspondente ao mês de julho, pouco diferiu da $5^{\mathrm{a}} \mathrm{e}$, principalmente, da $6^{\mathrm{a}}$ amostragem, que correspondem respectivamente, aos meses de setembro e outubro.

A espécie Saccharomyces cerevisiae: $S$. uvarum (S. cerevisiae) foi detectada em todas as amostragens mensais de mosto na Destilaria Mandú (Tabela 13), o que demonstra a persistência de tal contaminação ao longo destas amostragens. A análise da Tabela 13 revela ainda, grande diversidade de espécies e gêneros de leveduras ao longo das amostragens de mosto nesta unidade industrial, evidenciada particularmente, nas $1^{\mathrm{a}}, 2^{\mathrm{a}}$ e $4^{\mathrm{a}}$ amostragens mensais (respectivamente meses de maio, junho e agosto). As espécies de leveduras detectadas na $4^{\mathrm{a}}$ amostragem mensal, correspondente ao mês de agosto, também estiveram presentes na $1^{\mathrm{a}}$ amostragem, correspondente ao mês de maio, notando-se grande similaridade entre estas duas amostragens mensais. $\mathrm{Na} 3^{\mathrm{a}}$ amostragem mensal (mês de julho) e na $6^{\mathrm{a}}$ amostragem (mês de outubro), detectou-se a mesma espécie de levedura e a $5^{\text {a }}$ amostragem 
mensal de mosto (mês de setembro) não diferiu muito em relação à estas duas outras amostragens citadas.

Já, pela análise da Tabela 14, que demonstra as leveduras presentes nas amostragens mensais de leite de leveduras na Destilaria Mandú, observase certa persistência das espécies Saccharomyces cerevisiae: $S$. uvarum ( $S$. cerevisiae) e $S$. bayanus ao longo destas amostragens, pois a primeira espécie, esteve presente na maioria das amostragens mensais realizadas nesta unidade industrial, estando ausente apenas nas $1^{\text {a }}$ e $4^{\mathrm{a}}$ amostragens mensais, correspondendo respectivamente aos meses de maio e agosto. Já, a segunda espécie, foi detectada em 3 das 6 amostragens mensais de leite de leveduras, amostragens estas, correspondendo aos meses de maio, junho e agosto. Verificou-se ainda, diversidade de espécies de leveduras nestas amostragens mensais de leite de leveduras desta unidade industrial, particularmente na $4^{\mathrm{a}}$ amostragem, correspondendo ao mês de agosto, não havendo, contudo, variedade significativa em termos de gêneros.

A análise da Tabela 14 também demonstra, que a $2^{\mathrm{a}}$ amostragem mensal de leite de leveduras, correspondente ao mês de junho, pouco diferiu em relação à $1^{\mathrm{a}}$ amostragem, referente ao mês de maio e à $3^{\mathrm{a}}$ amostragem, referente ao mês de julho, sendo que esta última amostragem mensal também pouco variou em relação às $5^{\mathrm{a}}$ e $6^{\mathrm{a}}$ amostragens, que correspondem, respectivamente, aos meses de setembro e outubro.

Através de uma análise global das Tabelas 6, 9 e 12, que indicam as leveduras presentes nas amostragens mensais de caldo primário nas Usinas da Pedra, Santa Elisa e na Destilaria Mandú, respectivamente, observa-se 
que as leveduras que se destacaram nas amostragens mensais de caldo primário na Usina da Pedra (Tabela 6), foram as mesmas que também se destacaram nas amostragens mensais de caldo primário na Destilaria Mandứ (Tabela 12), ou seja, Candida entomophila, Saccharomyces cerevisiae: $S$. uvarum (S. cerevisiae) e $S$. coreanus ( $S$. cerevisiae). Vale ressaltar que, particularmente a espécie Candida entomophila foi detectada em todas as amostragens mensais de caldo primário na Usina da Pedra (Tabela 6), situação esta, bastante semelhante à verificada na Destilaria Mandú (Tabela 12), onde tal espécie não foi detectada apenas na última amostragem mensal desta unidade industrial.

A espécie Saccharomyces cerevisiae: $S$. uvarum (S. cerevisiae), apesar de ter sido detectada em apenas duas amostragens mensais de caldo primário na Usina Santa Elisa (Tabela 9), destacou-se, como já citado anteriormente, nas amostragens mensais de caldo primário na Usina da Pedra e na Destilaria Mandú (Tabelas 6 e 12, respectivamente). Contudo, os meses de setembro e outubro (correspondendo às duas últimas amostragens mensais), foram comuns para todas as unidades industriais na detecção desta espécie de levedura. Diversidade de espécies e gêneros, sempre foi observada ao longo das amostragens mensais de caldo primário nas 3 unidades industriais pesquisadas.

Também, através de uma análise global das Tabelas 7, 10 e 13, que indicam as leveduras presentes nas amostragens mensais de mosto nas Usinas da Pedra, Santa Elisa e na Destilaria Mandú, respectivamente, verifica-se que a espécie Saccharomyces cerevisiae: $S$. uvarum ( $S$. 
cerevisiae) destacou-se nas amostragens mensais de mosto tanto na Usina da Pedra (Tabela 7) como na Destilaria Mandú (Tabela 13). Contudo, pouca diversidade de espécies e, principalmente de gêneros de leveduras, foi observada ao longo das amostragens mensais de mosto na Usina da Pedra (Tabela 7), o contrário acontecendo em relação às amostragens mensais de mosto na Usina Santa Elisa e na Destilaria Mandú (Tabelas 10 e 13, respectivamente).

Finalmente, analisando as Tabelas 8, 11 e 14, que indicam as leveduras presentes nas amostragens mensais de leite de leveduras nas Usinas da Pedra, Santa Elisa e na Destilaria Mandú, respectivamente, observa-se que a espécie Saccharomyces cerevisiae: $S$. uvarum ( $S$. cerevisiae) destacou-se nas amostragens mensais de leite de leveduras nas 3 unidades industriais pesquisadas. Tais amostragens também revelaram diversidade de espécies e gêneros de leveduras nas unidades industriais analisadas, excetuando-se a Destilaria Mandú no que se refere aos gêneros detectados, uma vez que, pouca variação foi observada nesta unidade industrial.

Pela análise da Figura 18, que demonstra os gêneros de leveduras presentes nas 3 unidades industriais pesquisadas e suas respectivas porcentagens, observa-se que os gêneros Saccharomyces, Candida e Torulopsis, estiveram presentes nas 3 unidades industriais pesquisadas, enquanto o gênero Pichia foi detectado somente nas Usinas da Pedra e Santa Elisa. Observa-se também, que alguns gêneros foram exclusivos nas unidades industriais, como o gênero Schizosaccharomyces na Usina da 
Pedra, o gênero Trichosporon na Usina Santa Elisa e, finalmente, o gênero Rhodotorula na Destilaria Mandú.

Há grande concordância dos gêneros de leveduras detectados na presente pesquisa (Figura 18), com aqueles encontrados em diversos trabalhos de identificação de leveduras em unidades produtoras de açúcar e álcool, bem como na produção de aguardente, citados na literatura (item 3.3).

Dos 3 gêneros de leveduras (Saccharomyces, Candida e Torulopsis) detectados tanto nas Usinas da Pedra e Santa Elisa, como na Destilaria Mandú, os gêneros Saccharomyces e Candida foram os mais freqüentemente citados à nível de literatura, destacando-se, sobremaneira, o gênero Saccharomyces.

A maioria dos gêneros detectados nesta pesquisa, também são encontrados em processos fermentativos para a produção de vinho e de cerveja, como pode ser observado através da breve revisão de literatura realizada sobre o assunto (item 3.3).

A metodologia utilizada na presente pesquisa não permite a distinção de algumas espécies de leveduras, as quais possuem códigos numéricos comuns. Isto pôde ser evidenciado particularmente, com as espécies: Saccharomyces cerevisiae: S. uvarum e Candida krusei: Torulopsis castellii. Contudo, no primeiro caso, não há alteração em termos de gênero, o que não acontece no segundo caso, onde estão envolvidos os gêneros Candida e Torulopsis. Por isso, a Figura 18 indica também as unidades industriais (Usinas da Pedra e Santa Elisa) onde, particularmente, 
detectou-se Candida krusei: Torulopsis castellii, havendo, portanto, a possibilidade de se considerar um ou outro gênero, ou seja, Candida ou Torulopsis (Can/Tor).

Com relação às freqüências apresentadas para cada gênero detectado nas 3 unidades industriais, observa-se pela análise da Figura 18, que na Usina da Pedra houve dominância absoluta do gênero Saccharomyces (65,47\%), seguido pelo gênero Candida (19,59\%) e pelos gêneros Pichia (5,46\%), Torulopsis (4,08\%) e Schizosaccharomyces (2,7\%), estes 3 últimos com freqüências bastante inferiores em relação ao gênero dominante. Observa-se ainda, nesta unidade industrial, a freqüência de 2,7\% passível de pertencer ao gênero Candida ou ao gênero Torulopsis, conforme explicação anterior. Caso esta freqüência fosse considerada como sendo pertencente ao gênero Candida, a porcentagem total deste gênero nesta unidade industrial passaria de 19,59 para 22,29 . Se, ao contrário, a freqüência de $2,7 \%$ fosse considerada como pertencente ao gênero Torulopsis, então, a porcentagem total deste gênero passaria de 4,08 para 6,78, tornando o gênero Torulopsis mais freqüênte que o gênero Pichia.

A Figura 18 também demonstra, que o gênero Saccharomyces foi o de maior incidência na Usina Santa Elisa, com porcentagem de 58,2, seguido pelos gêneros Torulopsis (21,86\%), Pichia (9,06\%), Trichosporon (3,63\%) e Candida (3,62\%), observando as freqüências praticamente idênticas e bastante reduzidas dos 2 últimos gêneros. Como foi observado na Usina da Pedra, verifica-se também nesta unidade industrial, que uma freqüência de $3,63 \%$ é passível de pertencer ao gênero Candida ou ao gênero Torulopsis. 
Caso esta freqüência fosse considerada como sendo pertencente ao gênero Candida, a porcentagem total deste gênero nesta unidade industrial passaria de 3,62 para 7,25, tornando a freqüência deste gênero superior à do gênero Trichosporon. Contudo, se a freqüência de 3,63\% fosse considerada como pertencente ao gênero Torulopsis, então, a porcentagem total deste gênero passaria de 21,86 para 25,49.

O gênero Saccharomyces foi também o de maior incidência na Destilaria Mandú, com uma freqüência de $61,76 \%$, seguido do gênero Candida (32,36\%) e dos gêneros Torulopsis (4,41\%) e Rhodotorula $(1,47 \%)$, estes 2 últimos com freqüências bastante reduzidas em relação aos 2 primeiros gêneros (Figura 18).

Pela discussão dos dados abrangendo as 3 unidades industriais é interessante salientar que, o gênero Candida foi o $2^{\circ}$ gênero de maior deteç̧ão tanto na Usina da Pedra como na Destilaria Mandú, posição esta ocupada pelo gênero Torulopsis na Usina Santa Elisa. O gênero Pichia, ausente na Destilaria Mandú, foi o $3^{\circ}$ gênero de maior incidência nas Usinas da Pedra e Santa Elisa, ocupando o gênero Torulopsis esta mesma posição na Destilaria Mandú. $\mathrm{O} 4^{\circ}$ gênero de maior incidência na Usina da Pedra foi o Torulopsis, apesar da possibilidade da troca desta posição com o gênero Pichia nesta mesma unidade industrial. O gênero Trichosporon foi o $4^{0}$ gênero de maior deteç̧ão na Usina Santa Elisa, apesar da possibilidade da troca desta posição com o gênero Candida, o de menor incidência nesta unidade industrial. Os gêneros de menor incidência na Usina da Pedra e na 
Destilaria Mandú foram, respectivamente, Schizosaccharomyces e Rhodotorula.

Pela análise da Figura 18 e como verificado anteriormente, o gênero Saccharomyces foi o de maior incidência nas 3 unidades industriais pesquisadas, apresentando freqüências similares nestas unidades, ou seja, 65,47\% na Usina da Pedra, 58,2\% na Usina Santa Elisa e 61,76\% na Destilaria Mandú, observando-se, portanto, uma maior detecção deste gênero na Usina da Pedra. O gênero Candida apresentou freqüências bastante distintas em cada uma das unidades industriais, ou seja, 19,59\% na Usina da Pedra, 3,62\% na Usina Santa Elisa e 32,36\% na Destilaria Mandú, esta última unidade apresentando, portanto, maior porcentagem de detecção para este gênero. Já, o gênero Torulopsis, com freqüências de 4,08\% na Usina da Pedra, 21,86\% na Usina Santa Elisa e 4,41\% na Destilaria Mandú, teve maior porcentagem de deteç̧ão na Usina Santa Elisa e porcentagens bastante próximas, porém reduzidas, na Usina da Pedra e na Destilaria Mandú. O gênero Pichia detectado apenas nas Usinas da Pedra e Santa Elisa, apresentou freqüências de $5,46 \%$ e $9,06 \%$, respectivamente, freqüências relativamente baixas, porém superior na Usina Santa Elisa. Os gêneros Schizosaccharomyces, Trichosporon e Rhodotorula, detectados respectivamente nas Usinas da Pedra, Santa Elisa e na Destilaria Mandú, apresentaram-se com baixas freqüências nestas unidades industriais, ou seja, $2,7 \%, 3,63 \%$ e $1,47 \%$, respectivamente. 
Particularmente, os gêneros de leveduras detectados nas 3 unidades industriais pesquisadas (Figura 18), podem ainda, ser comparados à alguns dados da literatura.

Assim, o gênero Saccharomyces, que foi o gênero de maior incidência nas 3 unidades industriais analisadas, ou seja, Usina da Pedra (65,47\%), Usina Santa Elisa (58,2\%) e Destilaria Mandú (61,76\%), foi também o gênero de maior predominância em pesquisa realizada por Neder (1957), na identificação de leveduras na fabricação de aguardente, com freqüência de $51,5 \%$, freqüência esta, seguida pelo gênero Candida, com $47,3 \%$, o qual foi o $2^{\circ}$ gênero de maior freqüência tanto na Usina da Pedra $(19,59 \%)$, como na Destilaria Mandú (32,36\%).

Ainda, os trabalhos de Basso et al. (1994); Basso et al. (1995) e de Basso et al. (1996), demonstram que nas safras de 93/94, 94/95 e 95/96, respectivamente, os contaminantes detectados ao longo dos processos de produção de álcool se constituíram, basicamente, em leveduras do gênero Saccharomyces, gênero este também de maior detecção nas 3 unidades industriais pesquisadas.

De acordo com informações prestadas por técnicos das unidades industriais fornecedoras das amostras para a presente pesquisa e analisando os relatórios de pesquisa em fermentação nestas unidades, não se observou problemas sérios de queda de rendimento durante o período em que as amostragens foram realizadas, mostrando que as leveduras contaminantes detectadas e identificadas, provavelmente não se constituíram em grandes 
problemas, uma vez que, nenhum relato a este respeito foi feito durante a safra amostrada. 


\section{CONCLUSÕES}

O levantamento da variedade de espécies de leveduras presentes em processos de produção de álcool realizado nas Usinas da Pedra, Santa Elisa e na Destilaria Mandú, através da utilização de amostras de caldo primário, mosto e leite de leveduras, revelou:

- Identificação de um total de 26 espécies de leveduras pertencentes a 7 gêneros entre as 3 unidades industriais pesquisadas, à saber: Saccharomyces cerevisiae: S. uvarum (S. cerevisiae), S. coreanus (S. cerevisiae), S. bayanus, S. chevalieri (S. cerevisiae), S. globosus (S. cerevisiae), S. beticus (S. cerevisiae), S. capensis (S. cerevisiae), S. pretoriensis (Torulaspora pretoriensis), Candida entomophila, C. membranaefaciens, C. rugosa, C. parapsilosis, C. rhagii, C. krusei: Torulopsis castellii (Candida castellii), Torulopsis dattila (Kluyveromyces thermotolerans), T. haemulonii (Candida haemulonii), T. inconspicua (Candida inconspicua), Pichia membranaefaciens, P. guilliermondii, P. ohmeri, P. etchellsii, P. spartinae, P. terricola (Issatchenkia terricola), Schizosaccharomyces pombe, Trichosporon brassicae e Rhodotorula glutinis. 
- Maior incidência do gênero Saccharomyces, bem como da espécie Saccharomyces cerevisiae: S. uvarum (S. cerevisiae), nas 3 unidades industriais pesquisadas.

- O gênero Candida como um importante contaminante em processos de fermentação alcoólica, corroborando com dados da literatura, pois foi o $2^{\circ}$ gênero de maior incidência em duas unidades industriais pesquisadas no presente trabalho.

- Detecção dos gêneros Saccharomyces, Candida e Torulopsis nas 3 unidades industriais e ausência do gênero Pichia na Destilaria Mandú. Presença do gênero Schizosaccharomyces exclusivamente na Usina da Pedra, bem como presença exclusiva do gênero Trichosporon na Usina Santa Elisa e o gênero Rhodotorula somente na Destilaria Mandú.

- Grande diversidade de espécies de leveduras detectadas em cada unidade industrial pesquisada, sendo tal diversidade mais acentuada na Usina Santa Elisa.

- Maior diversidade de espécies de leveduras no caldo primário em comparação com o mosto e o leite de leveduras na Usina da Pedra.

- Maior diversidade de espécies de leveduras no leite de leveduras em comparação com o caldo primário e o mosto na Usina Santa Elisa. 
- Similaridade na diversidade de espécies de leveduras entre o caldo primário, mosto e o leite de leveduras na Destilaria Mandú.

- Eficiência da metodologia utilizada na identificação das leveduras, uma vez que, dos 225 isolados obtidos a partir das 3 unidades industriais pesquisadas, 195 puderam ser identificados, correspondendo à uma porcentagem de 86,6 . 


\section{REFERÊNCIAS BIBLIOGRÁFICAS}

AMERINE, M.A.; CRUESS, W.V. The technology of wine making. Westport: AVI Publ., 1960. cap.4, p.138-162: The molds and yeasts of grapes and wine.

AMERINE, M.A.; KUNKEE, R.E. Microbiology of winemaking. Annual Review of Microbiology, v.22, p.323-358, 1968.

AMORIM, H.V.; OLIVEIRA, A.J. de. Infecção na fermentação: como evitá-la. Álcool \& Açúcar, v.2, n.5, p.12-18, jul./ago. 1982.

AMORIM, H.V.; BASSO, L.C.; OLIVEIRA, A.J. de. Estudo das leveduras contaminantes da Usina Santo Alexandre. In: ESCOLA SUPERIOR DE AGRICULTURA "LUIZ DE QUEIROZ". Relatório anual de pesquisas em fermentação alcoólica - 1991. Piracicaba, 1991. p.5156. (Relatório, 11)

AMORIM, H.V.; OLIVEIRA, A.J. de; ZAGO, E.A.; BASSO, L.C.; GALLO, C.R. Processos de fermentação alcoólica, seu controle e monitoramento. Piracicaba: ESALQ/Centro de Biotecnologia Agrícola; FERMENTEC, 1989. 145p. 
ARCURI, E.F.; VARGAS, O.L.; PINTO, C.L. de O. Comportamento de bactérias láticas mesofilicas liofilizadas em presença de agentes crioprotetores. Revista do Instituto de Laticínios Cândido Tostes, v.43, n.260, p.16-27, nov./dez. 1988.

BARNETT, J.A.; PAYNE, R.W.; YARROW, D. Yeasts: characteristics and identification. Cambridge: University Press, 1983. 811p.

BARNETT, J.A.; PAYNE, R.W.; YARROW, D. Yeasts: characteristics and identification. 2.ed. Cambridge: University Press, 1990. 1002p.

BASSO, L.C.; AMORIM, H.V.; OLIVEIRA, A.J. de. Acompanhamento e seleção de leveduras do processo pela técnica da cariotipagem. In: ESCOLA SUPERIOR DE AGRICULTURA "LUIZ DE QUEIROZ". Relatório anual de pesquisas em fermentação alcoólica - 1995. Piracicaba, 1995. p.1-56. (Relatório, 15)

BASSO, L.C.; AMORIM, H.V.; OLIVEIRA, A.J. de. Leveduras selecionadas: permanência no processo industrial monitorada pela técnica da cariotipagem. In: ESCOLA SUPERIOR DE AGRICULTURA “LUIZ DE QUEIROZ”. Relatório anual de pesquisas em fermentação alcoólica - 1996. Piracicaba, 1996. p.1-51. (Relatório, 16) 
BASSO, L.C.; AMORIM, H.V.; OLIVEIRA, A.J. de; ORELLI, V.F.D.M. Identificação de leveduras pela técnica da eletroforese do DNA cromossômico: cariotipagem. In: ESCOLA SUPERIOR DE AGRICULTURA “LUIZ DE QUEIROZ”. Relatório anual de pesquisas em fermentação alcoólica - 1992. Piracicaba, 1992. p. 101108. (Relatório, 12)

BASSO, L.C.; AMORIM, H.V.; OLIVEIRA, A.J. de; ORELLI, V.F.D.M. Estabilidade da levedura em condições industriais avaliada pela técnica da cariotipagem durante a safra 93/94. In: ESCOLA SUPERIOR DE AGRICULTURA "LUIZ DE QUEIROZ". Relatório anual de pesquisas em fermentação alcoólica - 1994. Piracicaba, 1994. p.1-43. (Relatório, 14)

BASSO, L.C.; AMORIM, H.V.; OLIVEIRA, A.J. de; CAMPOS, A.A.; ORELLI, V.F.D.M. Estabilidade da levedura em condições industriais avaliada pela técnica da cariotipagem (separação eletroforética do DNA cromossômico). In: ESCOLA SUPERIOR DE AGRICULTURA “LUIZ DE QUEIROZ”. Relatório anual de pesquisas em fermentação alcoólica - 1993. Piracicaba, 1993. p.79-95. (Relatório, 13) 
BEVAN, D.; BOND, J. Microorganisms in field and mill: a preliminary survey. In: QUEESLAND SOCIETY OF SUGAR CANE TECHNOLOGISTS, 38., Caims, 1971. Proceedings. Brisbane: Watson Ferguson, 1971. p.137-143.

BOVI, R.; MARQUES, M.O. O tratamento ácido na fermentação alcoólica. Álcool \& Açúcar, v.3, n.9, p.10-12, mar./abr. 1983.

CAMHI, J.D. A fermentação alcoólica e sua otimização. Brasil Açucareiro, v.94, n.2, p.34-40, ago. 1979.

COOPERATIVA CENTRAL DOS PRODUTORES DE AÇÚCAR E ÁLCOOL DO ESTADO DE SÃO PAULO. Controle microbiológico na fabricação de açúcar e álcool. Boletim Técnico COPERSUCAR, n.22, p.2-17, maio 1983a.

COOPERATIVA CENTRAL DOS PRODUTORES DE AÇÚCAR E ÁlCOOL DO ESTADO DE SÃO PAULO. Manual de controle microbiológico da usina de açúcar e álcool. Cadernos COPERSUCAR. Série Industrial, n.5, p.1-10, abr. 1983b.

CORRÊA, B.; PAULA, C.R.; MINAMI, P.S. (Coord.) Biologia e identificação de leveduras. São Paulo: USP/ICB; FCF, 1991. 63p. (Apostila do Curso Prático) 
FERRARI, S.E.; LOPES, J.J.C.; LEME, J.R.A.; OLIVEIRA, E.R. de. Industrial efficiency of alcohol fermentation: a comparative study. In: INTERNATIONAL SYMPOSIUM ON ALCOHOL FEELS TECHNOLOGY, 4., Guarujá, 1980. Anais. Guarujá: IPT, 1980. p.139141.

FLEET, G.H.; LAFON-LAFOURCADE, S.; RIBÉREAU-GAYON, P. Evolution of yeasts and lactic acid bacteria during fermentation and storage of Bordeaux wines. Applied and Environmental Microbiology, v.48, n.5, p.1034-1038, Nov. 1984.

FRANCO, C.J. Fermentação alcoólica. Saccharum, v.1, n.3, p.31-36, dez. 1978.

GALLO, C.R. Identificação de bactérias contaminantes da fermentação alcoólica. STAB. Açúcar, Álcool e Subprodutos, v.10, n.5, p.30-34, maio/jun. 1992.

GERMEK, H.A. Emprego do fermento selecionado na obtenção de álcool. Boletim Técnico COPERSUCAR, v.78, n.6, p.9-11, maio 1978.

GRIFFITHS, A.J. A numericlature of the yeasts. Antonie-van Leeuwenhoek, v.47, n.6, p.547-563, 1981. 
GUTIERREZ, L.E. Tópicos de bioquímica de leveduras. Piracicaba: ESALQ/Depto. de Química, 1994. 103p. (NAPMA, 1)

HEARD, G.M.; FLEET, G.H. Growth of natural yeast flora during the fermentation of inoculated wines. Applied and Environmental Microbiology, v.50, n.3, p.727-728, Sept. 1985.

HEARD, G.M.; FLEET, G.H. Occurrence and growth of yeast species during the fermentation of some Australian wines. Food Technology in Australia, v.38, n.1, p.22-25, Jan. 1986.

HOUGH, J.S. Biotecnologia de la cerveza y de la malta. Cambridge: University Press, 1990. cap.7, p.109-131: Levaduras y bacterias.

KLEYN, J.; HOUGH, J. The microbiology of brewing. Annual Review of Microbiology, v.25, p.583-608, 1971.

KREGER-van RIJ, N.J.W. The yeasts: a taxonomic study. 3.ed. Amsterdam: Elsevier Science, 1984. 1082p.

KUNKEE, R.E.; BISSON, L.F. Wine-making yeasts. In: ROSE, A.H.; HARRISON, J.S. (Ed.) The yeasts: yeast technology. London: Academic Press, 1993. v.5, cap.3, p.69-127. 
LIMA, U.A. Produção do etanol. In: LIMA, U.A.; AQUARONE, E.; BORZANI, W. (Ed.) Biotecnologia: tecnologia das fernentações. São Paulo: Edgard Blücher, 1975. v.1, cap.3, p.49-69.

LIMA, U.A.; GOLDONI, J.S.; CEREDA, M.P.; SOUZA, L.G. de. Ocorrência de microrganismos em caldo bruto, caldo misto e água de embebição em uma usina de açúcar de cana. Brasil Açucareiro, v.83, n.4, p.21-27, abr. 1974.

LOURENCINI, V.F. Manual para manutenção de destilarias autônomas de álcool e fermentação alcoólica. Piracicaba: Dedini Metalúrgica, 1990. 90p.

MACCIONI, L. Ecologia da dorna de fermentação na produção de etanol industrial: incidência de leveduras selvagens. Rio Claro, 1984. 62p. Monografia (Graduação) - Instituto de Biociências, Universidade Estadual Paulista "Júlio de Mesquita Filho".

MAIORELLA, B.L. Ethanol. In: MOO-YOUNG, M. (Ed.) Comprehensive biotechnology: the principles, applications \& regulations of biotechnology in industry, agriculture and medicine. Oxford: Pergamon Press, 1985. v.3, cap.43, p.861-914. 
MINIAC, M. de. Contamination des fermentations alcooliques industrielles par les levures du genre: Brettanomyces. Industries Alimentaires et Agricoles, v.106, n.7-8, p.559-563, jui./aôu. 1989.

MORA, J.; BARBAS, J.I.; RAMIS, B.; MULET, A. Yeast microflora associated with some Majorcan musts and wines. American Journal Enology and Viticulture, v.39, n.4, p.344-346, 1988.

NEDER, R.N. Contribuição ao estudo de algumas leveduras regionais de fábricas de aguardente de cana: posição sistemática e valor industrial. Piracicaba, 1957. 79p. Tese (Doutorado) - Escola Superior de Agricultura "Luiz de Queiroz", Universidade de São Paulo.

OLIVEIRA, A.J. de; GALLO, C.R.; ALCARDE, V.E.; GODOY, A.; AMORIM, H.V. Métodos para o controle microbiológico na produção de álcool e açúcar. Piracicaba: ESALQ/Depto. de Química; FEALQ; FERMENTEC, 1996. 89p.

OLIVEIRA, M.C.F.L. de. Leveduras contaminantes da fermentação etanólica. In: SEMINÁRIO SOBRE MICROBIOLOGIA DA FERMENTAÇÃO ETANÓLICA, 1., Rio Claro, 1987. Microbiologia da fermentação etanólica. Rio Claro: UNESP, Instituto de Biociências, 1987. p.92-104. 
OLIVEIRA, M.C.F.L. de; PAGNOCCA, F.C. Aplicabilidade de meios seletivos empregados na indústria cervejeira para deteç̧ão de leveduras selvagens em unidades sucro-alcooleiras. In: SIMPÓSIO NACIONAL DE FERMENTAÇÃO, 8., São Lourenço, 1988. Anais. São Lourenço: SBM, 1988. p.78-81.

OLIVEIRA, M.C.F.L. de; SILVA, R.B.O. de. Biotipo Saccharomyces cerevisiae em cadeias multicelulares ramificadas na fermentação contínua. In: CONGRESSO BRASILEIRO DE MICROBIOLOGIA, 17.; SIMPÓSIO NACIONAL DE FERMENTAÇÃO, 10., Santos, 1993. Resumos. Santos: SBM, 1993. p.79.

PANCHAL, C.J.; TAVARES, F.C.A. Yeast strain selection for fuel ethanol production. In: PANCHAL, C.J. (Ed.) Yeast strain selection. New York: Marcel Dekker, s.d. cap.8, p.225-243.

RAINBOW, C. Brewer's yeasts. In: ROSE, A.H.; HARRISON, J.S. (Ed.) The yeasts: yeast technology. London: Academic Press, 1970. v.3, cap.4, p.147-224.

RASOVSKY, E.M. Álcool: destilarias. Rio de Janeiro: IAA, 1973. cap.13, p.289-311: Fermentação. 
REINOLD, M.R. Pontos fracos na microbiologia cervejeira. Engarrafador Moderno, v.6, n.42, p.70-74, nov./dez. 1995.

ROSINI, G. Assessment of dominance of added yeast in wine fermentation and origin of Saccharomyces cerevisiae in wine-making. The Journal of General and Applied Microbiology, v.30, n.4, p.249-256, Aug. 1984.

SHEHATA, A.M. EL-TABEY. Yeasts isolated from sugar cane and its juice during the production of aguardente de cana. Applied Microbiology, v.8, n.2, p.73-75, Mar. 1960.

SILVA, R.B.O. de. Leveduras contaminantes na produção de etanol industrial por processo contínuo: quantificação e identificação. Rio Claro, 1994. 145p. Dissertação (M.S.) - Instituto de Biociências, Universidade Estadual Paulista "Júlio de Mesquita Filho".

SMIBERT, R.M.; KRIEG, N.R. General characterization. In: GERHARDT, P. (Ed.) Manual of methods for general bacteriology. Washington: American Society for Microbiology, 1981. cap.20, p.409443. 
SOUZA, M.A.C.; MARQUES, M.O.; MELLO, W.J. de. Caracterização de leveduras em caldo primário e mosto. In: CONGRESSO NACIONAL DA SOCIEDADE DOS TÉCNICOS AÇUCAREIROS E ALCOOLEIROS DO BRASIL, 5., Águas de São Pedro, 1993. Anais. Piracicaba: STAB, 1994. p.235-240.

STUPIELLO, J.P. Qualidade da cana-de-açúcar para a fabricação de açúcar e álcool: parte 1. Álcool \& Açúcar, v.1, n.1, p.17-20, nov. 1981.

STUPIELLO, J.P. Qualidade da cana-de-açúcar para a fabricação de açúcar e álcool: parte 2. Álcool \& Açúcar, v.2, n.2, p.28-32, jan. 1982.

STUPIELLO, J.P.; HORII, J. Condução da fermentação alcoólica. Saccharum, v.4, n.17, p.43-46, nov. 1981.

TAVARES, F.C.A. Processo de controle seletivo de leveduras contaminantes. STAB. Açúcar, Álcool e Subprodutos, v.10, n.5, p.4549, maio/jun. 1992.

THOMAS, D.S. Yeasts as spoilage organisms in beverages. In: ROSE, A.H.; HARRISON, J.S. (Ed.) The yeasts: yeast technology. London: Academic Press, 1993. v.5, cap.13, p.517-561. 
THOMAS, R.W.S.P. A microflora dos produtos engarrafados. Engarrafador Moderno, v.7, n.47, p.69-74, set./out. 1996.

YANAGIDA, F.; ICHINOSE, F.; SHINOHARA, T.; GOTO, S. Distribution of wild yeasts in the white grape varieties at Central Japan. The Journal of General and Applied Microbiology, v.38, n.5, p.501-504, Oct. 1992.

YOKOYA, F. Problemas com contaminantes na fermentação alcoólica. STAB. Açúcar, Álcool e Subprodutos, v.9, n.6, p.38-39, jul./ago. 1991. 